\title{
تصور مقترح لتطوير الكفايات الأدائية لمعلمات رياض الأطفال في ضوء متطلبات العصر الرقمي
}

\author{
إعداد \\ د/ إيمان فؤاد محمد البرقي
}

مقدمة:

يثهد العصر الحالي تطوراً تكنولوجياً كبيراً وثورةً معلوماتية في مختلف المجالات، مما حتم علينا إعداد

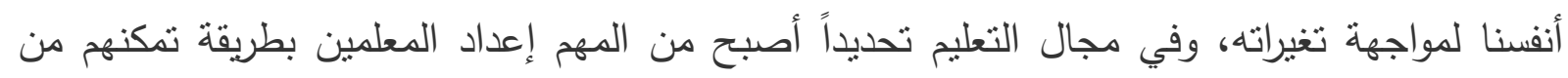

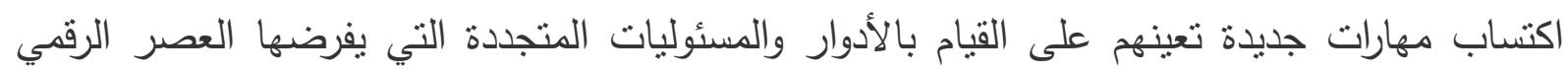

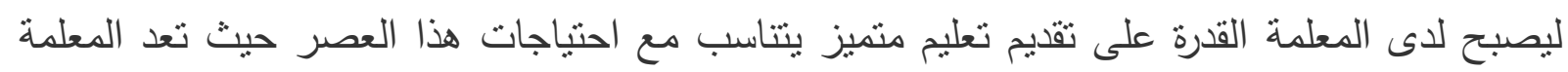

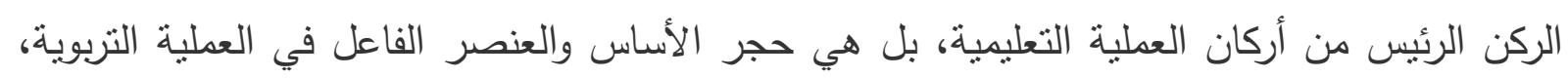

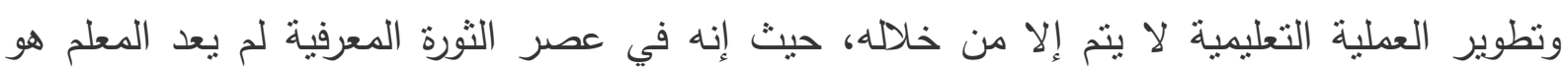
مصدر المعرفة الوحيد، فقد تعددت المعارف وتتوعت طرق الوصول إليها، وأصبح دور المعلم وسيطاً بين الإني

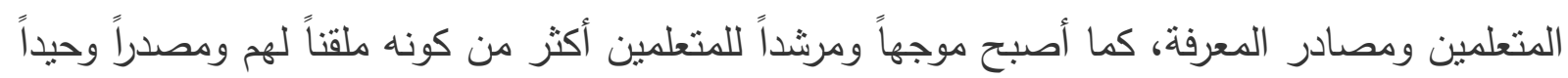
للمعرفة.

وفي ظل هذه التطورات السريعة والمتلاحقة للتكنولوجيا في العصر الرقمي، كان لابد أن تتغير أدوار

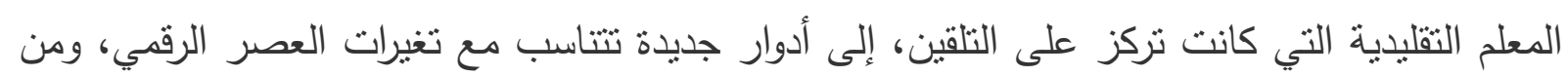

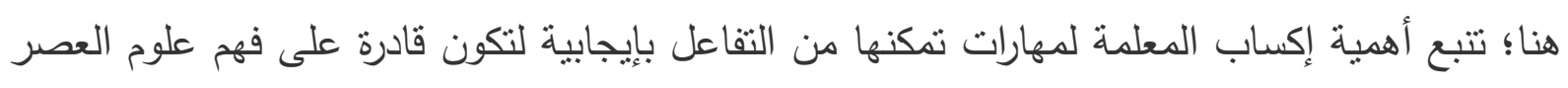

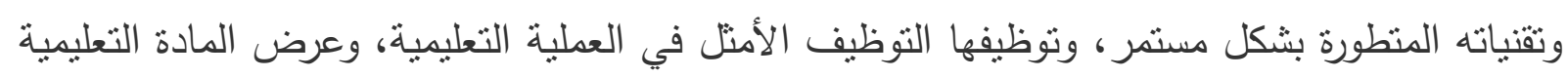
بطريقة متميزة، وهذا يتطلب ضرورة إعداد وتدريب المعلمين على كيفية توظيف هذه التقنيات في العملية التعليمية، وامتلاك استراتيجيات التدريس والتقويم المناسبة للتعامل مع تعليم العصر الرقدي.

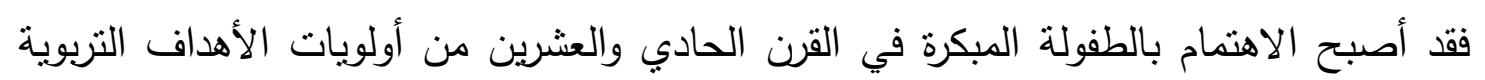

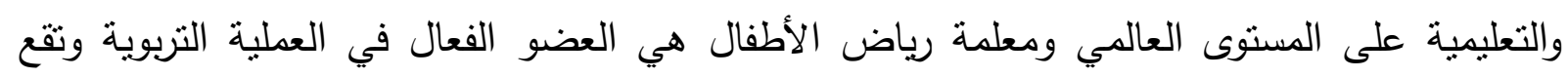

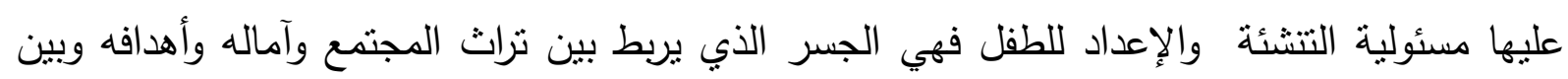
واقع الأطفال وعقولهم، لذلك حرص البرنامج التربوي على إعداد معلمة رياض الأطفال وتزويدها

*مدرس بقسم العلوم التربوية - كلية التربية للطفولة المبكرة - جامعة مدينة السادات 
بالكفايات الضرورية اللازمة للتعامل مع المعرفة من جهة، ومع الأطفال من جهة أخرى (أبو حرب، .). (AV ، Y... مشكلة البحث: يتعرض العالم لعدد من التغيرات كالتقدم التكنولوجي الدذهل وثثرة المعلومات في العصر الرقمي،فسارعت

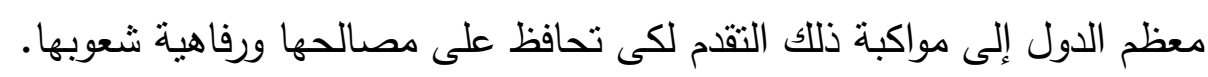

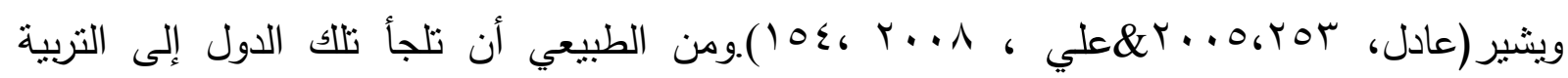

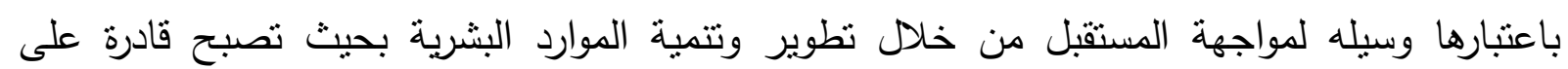

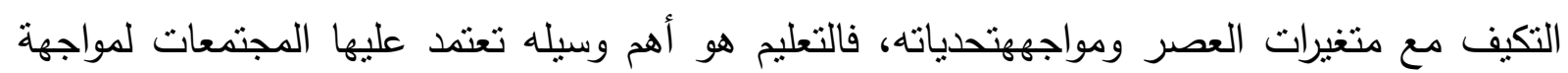
متغيرات الحاضر وتحديات المستقبل

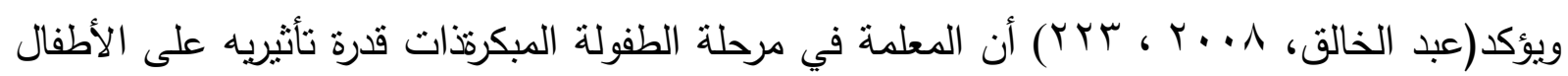

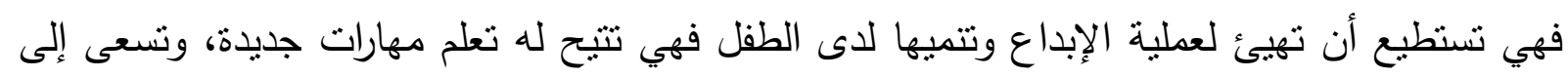

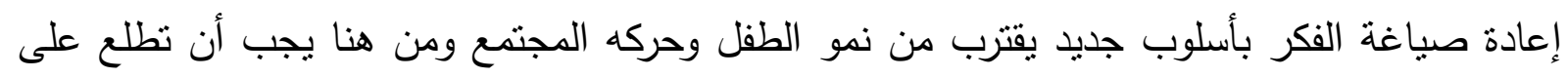

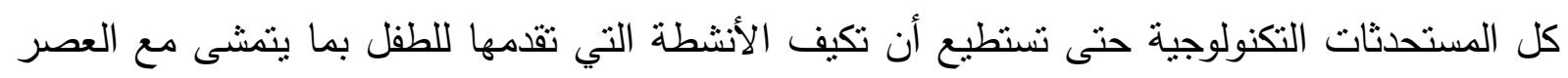
الرقميوذلك حتى يتمالتطوير والتجديد الدائم الذي يناسب طفل هذه المرحلة، ومن خلاد وإطلاع الباحثة

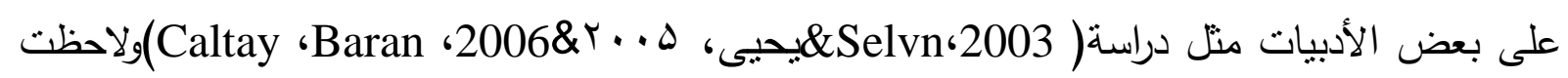

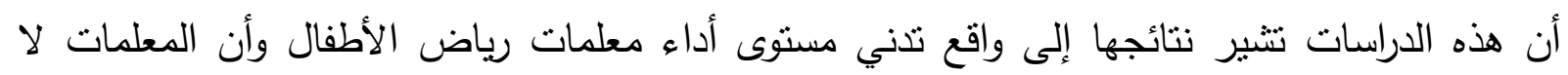

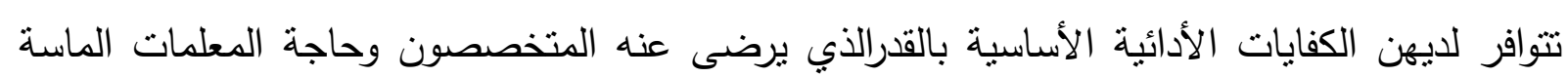

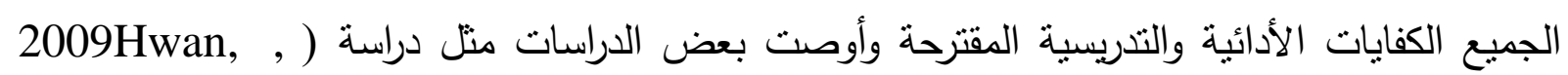
(Kung

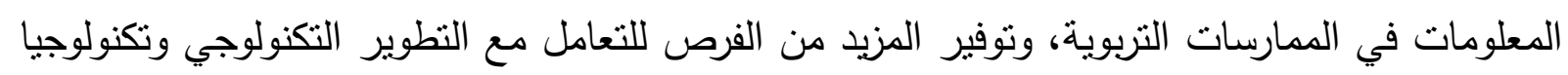

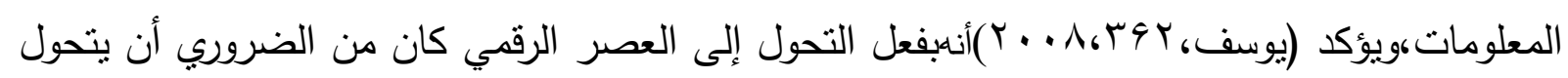
دور معلمة رياض الأطفال ويعاد تشكيله.

\section{ويناءً على ما سبق فقد تمت صياغة مشكلته في التساؤل الرئيسي التالي :}

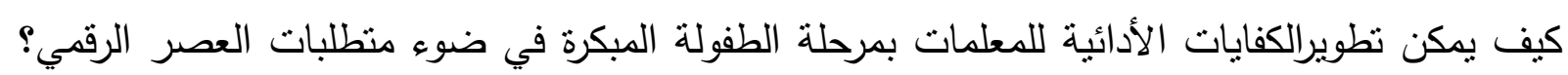
ويتقرع عنه النساؤلات التالية: 1- ما الإطار الدفاهيمي للكفايات الأدائيةلمعلمات رياض الأطفال؟

$$
\text { r- با أهم منطلبات العصر الرقمي؟ }
$$

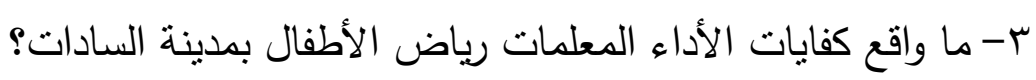

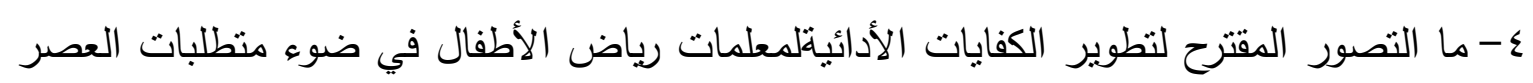


أهداف البحث:يهدف البحث إلى: نطويرالكفايات الأدائيةللمعلمات بمرحلة الطفولة المبكرة في ضوء منطلبات العصر الرقمي وذلك من خلا: 1- التعرف على الكفايات الأدائيةللمعلمات بمرحلة الطفولة المبكرة. r- التعرف على أهم متطلبات العصر الرقمي. r- بتخيص واقع للمعلمات بمرحلة الطفولة المبكرة بمدينة السادات. ع-وضع تصور مقترح لنطويرللمعلمات بمرحلة الطفولة المبكرة في ضوء منطلباتالعصر الرقمي. أهمية البحث:تتبع أهمية البحث من حداثة موضوعه، حيث توضح الكفايات الأدائية للمعلمات بمرحلة الطفولة المبكرة ، والسعي إلى تطوير تلك الكفايات بما يتتاسب مع التقام العلمي والتكنولوجي، والارتقاء

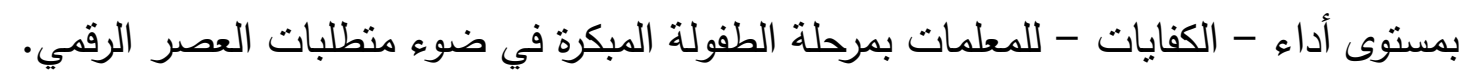

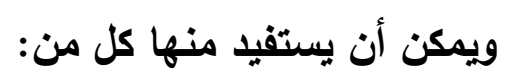
- - المعلمات بمرحلة الطفولة المبكرة. - الوزارات والمؤسسات التزبوية المختصة بتطويرالمعلمات بمرحلة الطفولة المبكرة. - المسئولون المعنيون بتطوير برامج إعداد المعلمات بمرحلة الطفولة المبكرة ، وكذلك المعنيون

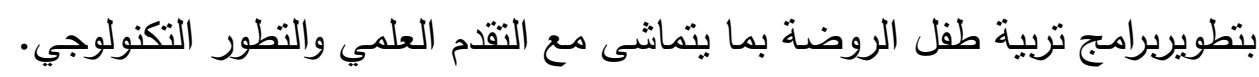

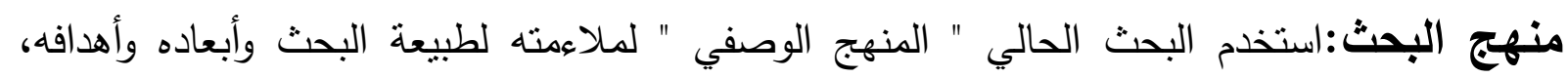
ويعتمد على دراسة الظاهرة كما توجد في الواقع، ويعبر عنها كماً وكيفاًمن خلال رصد كفايات الأداء

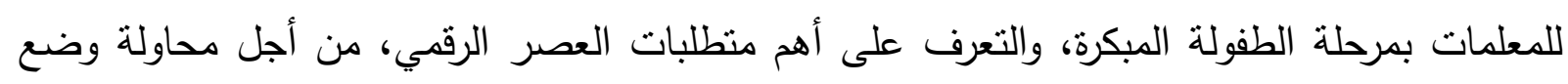

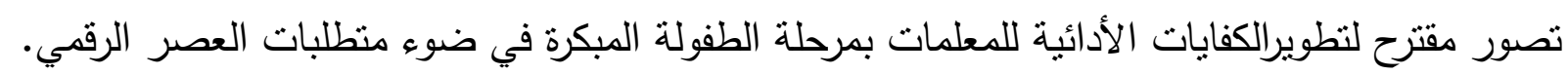
فروض البحث:

1- لا توجد فروق ذات دلالة إحصائية بين آراء أفراد عينة البحث في عبارات الدحور الأول (واقع

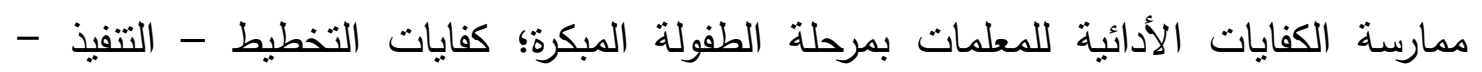
التقويم) ץ- لا توجد فروق ذات دلالة إحصائيةبين آراء أفراد عينة البحث لعبارات المحور الثاني( الشكلات

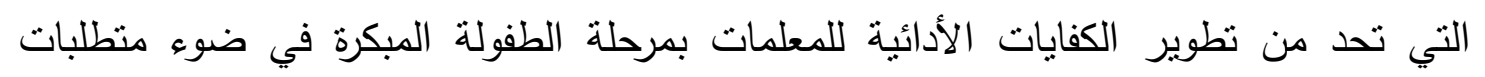
العصر الرقمي؛ مايخص التجهيزات - مايخص التدريب)

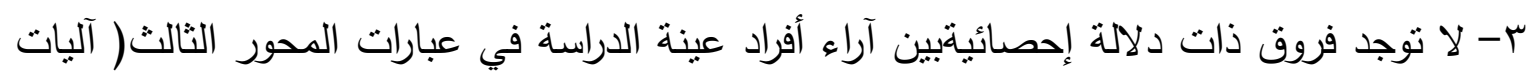

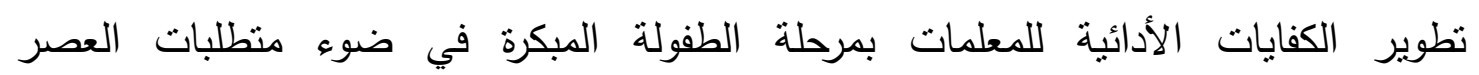
الرقمي؛مهارات التفكير العليا والتفكير الناقد- مهارات الحياة - نوظيف التكنولوجيا) 
ع - لا توجد فروق ذات دلالة احصائية بين محاور الاستبانة التلاث وأبعادها المختلفة يرجع لمتغيري

$$
\text { الربف والحضر • مان }
$$

ه- لا توجد علاقة ارتباط ذات دلالة احصائية محاور الاستبانة الثلاث وأبعادها المختلفة

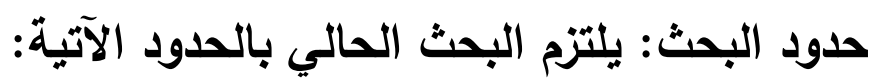

ا- الحدود البشرية:تكونت عينة البحث من (

الحكومية التي تتضمن فصول رياض أطفال بالإدارات المختلفة بمحافظة المنوفية

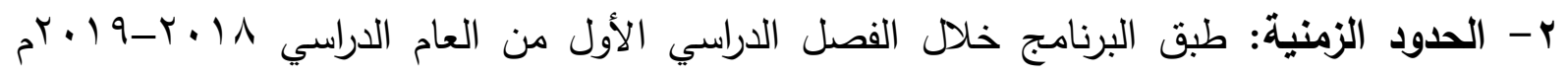

وقامتالباحثة بتطبيق الاستبانة للنأكد من دقة التطبيق.

ب-الحدود المكانية:تم اختيار عينة الدراسة بطريقة قصديةطبقية من المدارس الحكومية بالإدارات

التعليمية بمحافظة المنوفية.

أداة البحث:في ضوء الأهداف التي تسعى الدراسة الميدانية لتحقيقها استخدمت الباحثة الاستبانة للتعرف على كيفية تطوير الكفايات الأدائية للمعلمات بمرحلة الطفولة المبكرة في ضوء متطلبات العصر الرقمي مصطاح البحث:

\section{الكفايات: Competencies.}

يعرفها (رشدي ، ج . . r ، سب) " مختلف أشكال الأداء التي تمنل الحد الأدنى الذي يلزم التحقيق هدف ما "، إنها بعبارة أخري وبتفصيل أكثز : مجموع الإتجاهات وأنشال الفهم والمهارات التي من شأنها أن نيسر للعملية التعليمة لتحقيق أهدافها العقلية والوجدانية والنفس حركية.

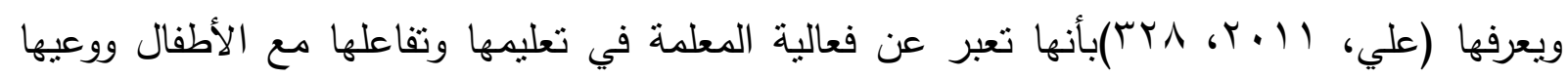
للعلاقة بين سلوكها والتأثير الذي تُحدثه على نمو الأطفال، وتأثنراتها الإيجابيةعلى المدى البعيد. أي أنها القدرات التي تتيح للأطفال امتلاكها أثناء العملية التعليمية، والمهارات الأدائية، والاتجاهات والقيم، وما يرتبط بها من خبرات توجه سلوكها وترتقي بأدائها إلى مستوى معين من التمكن مع اقتصاد في الجهد والوقت والنفقات.

ويعرفها البحث الحالي إجرائياً بأنها: قدرة معلمة الروضة على توظيف مجموعه مرتبة من المعارف وأنماط السلوك والمهارات أثناء أدائها لأدوارها التعليمية داخل القاعة والارتقاء لمستوى معين من الإتقان يمكن ملاحظته وتقويمه.

\section{العصر الرقمي: Digital Age}

يعرفها (نبيل، نادية، 9 (، ، . . ب)بأنه منظومة تحوي ثلاثة أبعاد رئيسة هي المكونات المادية، والبرمجيات، والموارد المعرفية. 


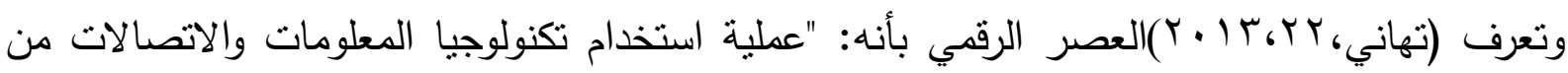
أجهزة حواسيب وشبكات وبرمجيات لغرض تتظيم وخزن المعلومات ومعالجتها وتتاقلها واستخدامها والمحافظة على أمنها وحمايتها وضمان إدامتها ". ويعرفه البحث الحالي إجرائيا بأنه: كل ما تحتاج إليه المعلمات كي تعطلن بكفاءة في مجتمع يعتمد على المانى

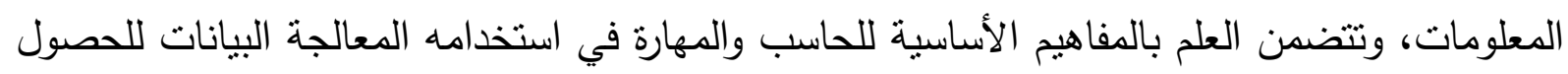
على المعلومات التي تناعد في تتمية قدراتها في التعامل مع أطفالالروضة التهانة الإطار النظري: للتعليم دور مهم في حياة الإنسان، حيث يزوده بالمعلومات والقيم والمهارات والمعرفة حتى يصبح ذب دور

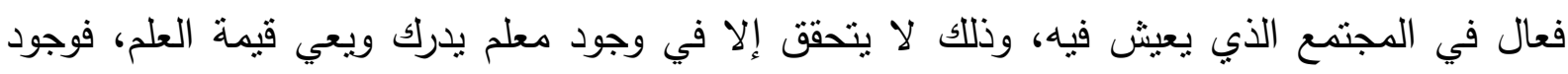

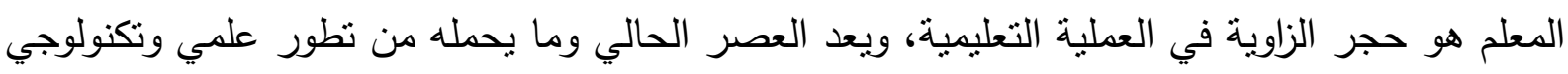

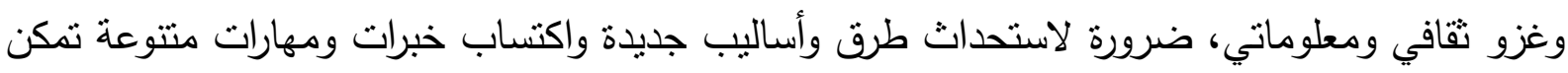

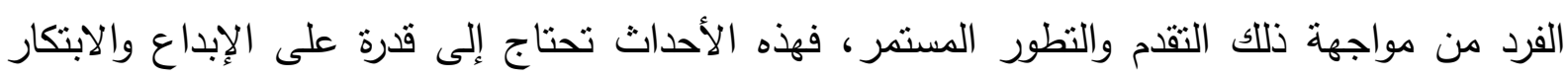

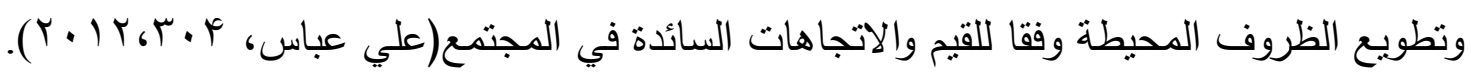

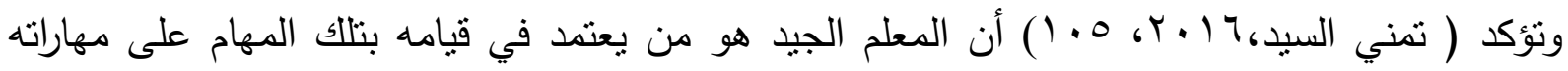

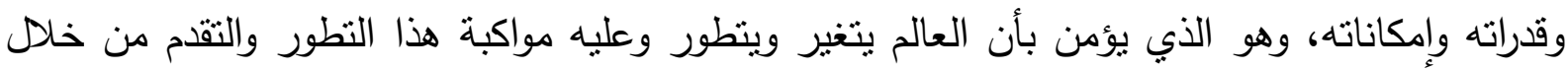
تتميته لذاته ومهاراته وإمكاناته ومعارفه ومعلوماته. المحور الأول: الكفايات الأدائية: تعد الكفايات من أهم المتطلبات اللازمة للنجاح في أي مهنة، فبدونها لا يتمكن الفرد من القيام

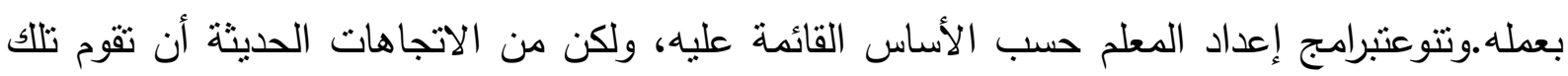

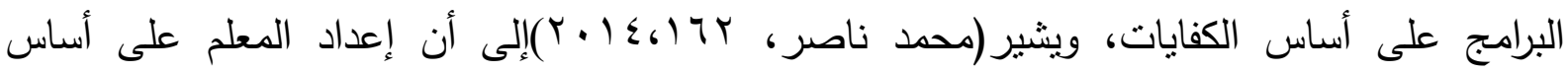
الكفايات والتثريب عليها يتم عبر مرحلتين هما: - المرحلة الأولى: مرحلة الطالب المعلم" أي اثثاء الدراسة من خلال تدريبه على اثلى الثان التدريس وتقويمه ومدى اكتسابه للمهارات التي سوف يقوم بها.

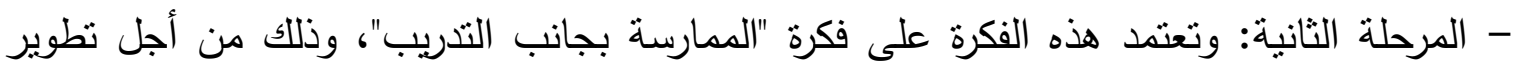

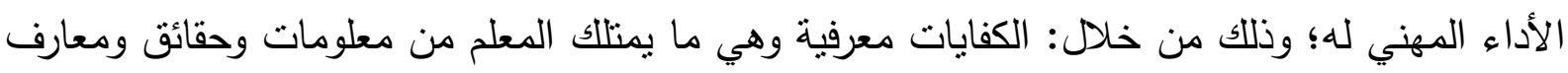

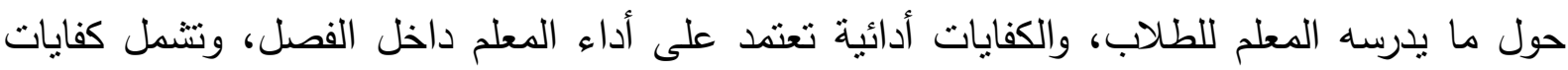

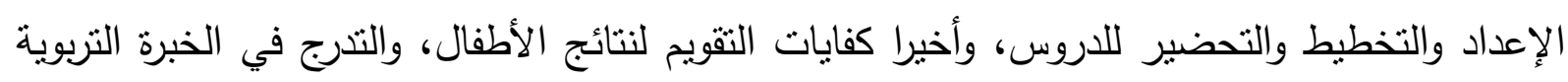
من السهل إلى الصعب فالأصعب، وتحليل السلوكيات المرتبطة بالمادة العلمية وتصنيفها إلى فئات تتضمن كل فئة منها جوانب متعددة كالفهم والمعرفة والإدرالك والتحليل. 
مفهوم الكفايات الأدائية للمعلماتبمرحلة الطفولة المبكرة:

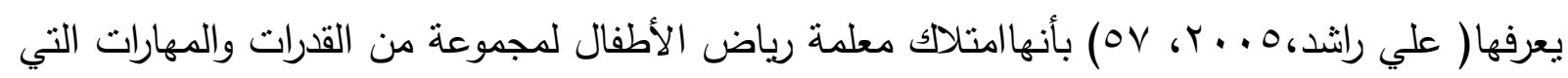

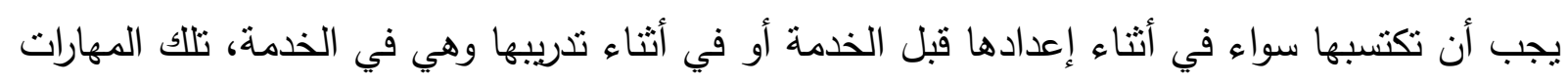

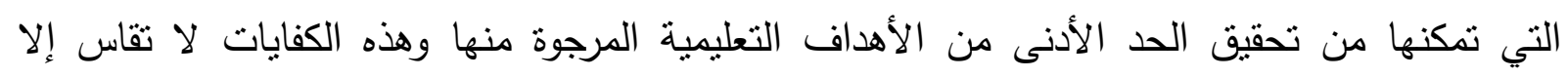

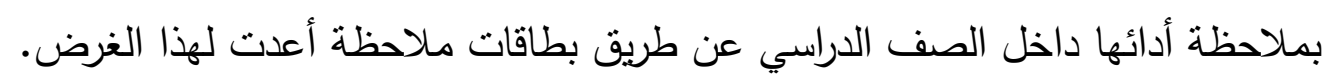

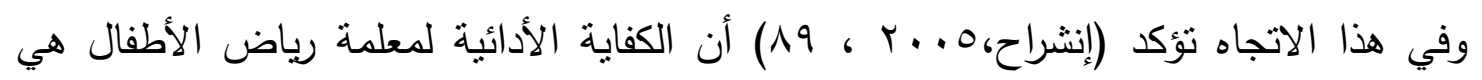

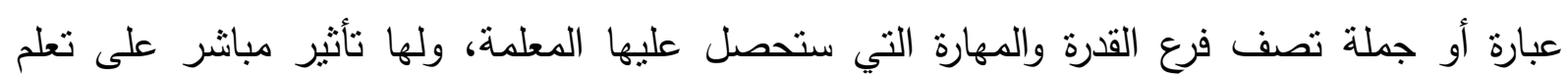
الأطفال، وكذلك فهي القدرة على استعمال مهارات خاصة ومهارات مهنية لتلبية منطلبات موقف معين.

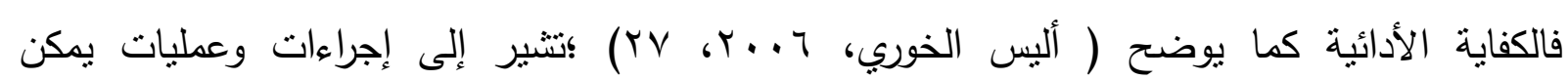

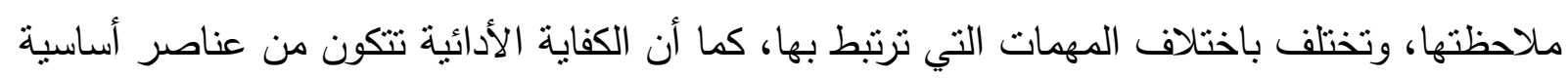

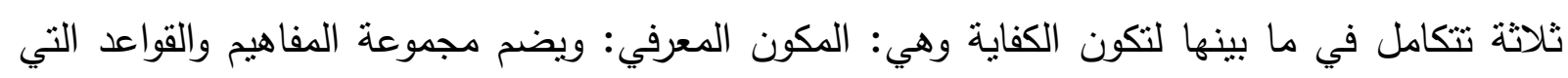
تتصل بالكفاية، المكون العملي: مجموعة الأعمال التي تمكن صاحب المهنة المكنة من إنجاز المهمات المنوطة

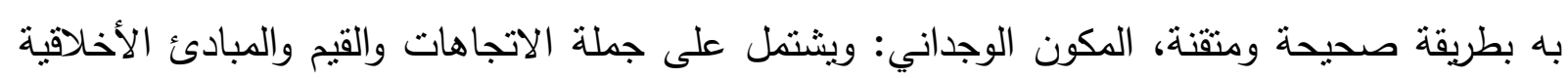
والمواقف الإيجابية التي تتصل بالمهنة ومجالها.

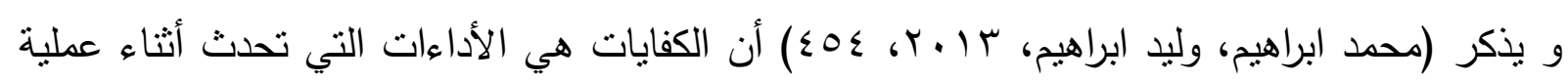

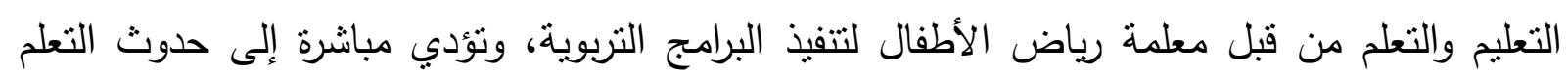

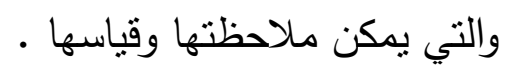

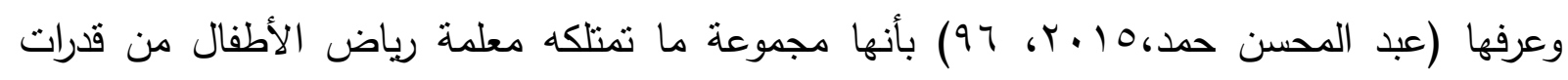

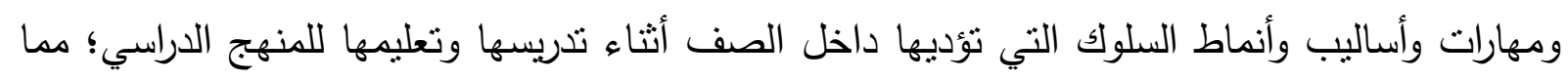
يجعلها قادرة على أداء مهمتها بكفاءة داخل الصف، وهذه الكفايات يمكن ملاحظتها وقياسها بوضوح باستخدام الأدوات المعدة لذلك. ويتضح للبحث من خلال ما سبق أن امتلاك معلمة رياض الأطفال لبعض القدرات أثناء العملية

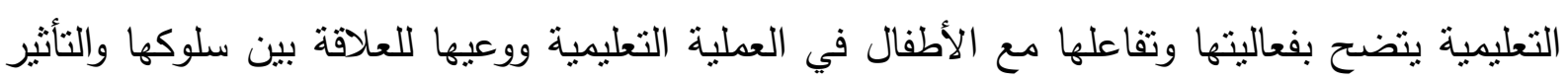
الذي تحدثه في علاقتها معهم في سن مبكرة.

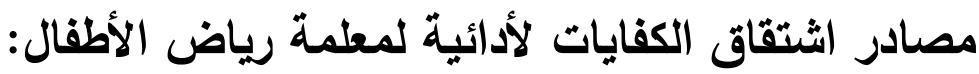

يستقي التربويون الكفايات الأدائية لمعلمة رياض الأطفال بصفة عامة، والعدئه العديد من الأساليب التي تمكنهم

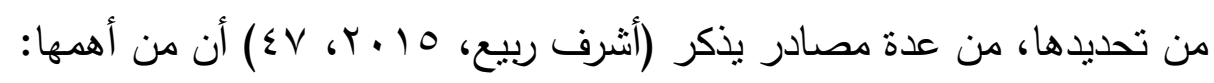

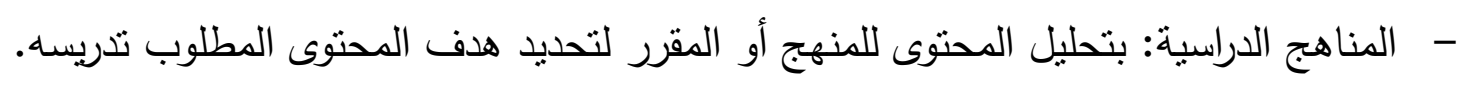
- خبراء المهنة: التربوبين المقيمين على العملية التعليمية. - - برامج كليات التربية: تهدف إلى عمل الأبحاث لتتوصل إلى مجموعات مثتوعة من الكفايات. 
- - تحليل مهام المعلم: توضيح مسئولياته التي يقوم بها المعلم وأوجه الضعف في برامج الإعداد. - الأطفال والمجتمع: بدراسة احتياجات الأطفال بما يتتاسب مع المجتمع ومدى تأثثر المعلم. - تحليل أداء المعلمين : رصد الأداء والسلوك للمعلم. أبعاد الكفايات الأدائية لمعلمة رياض الد الأطفال:

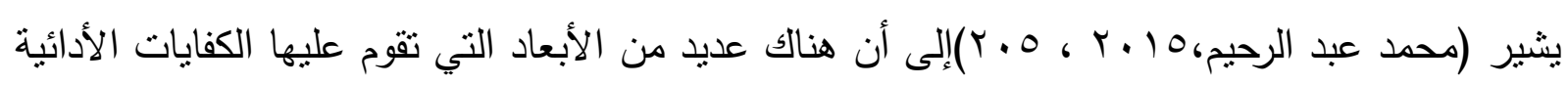
لمعلمة رياض الأطفال منها: - - البعد الأخلاقي: التزام المعلمة بأخلاقيات مهنة التعليم وبالتطوير المستمر بجميع الجوانب. - البعد الأكاديمي: امتلاك المعلمة للمعارف التي تمكنها من القيام بمهمة التدريس بفعالية.

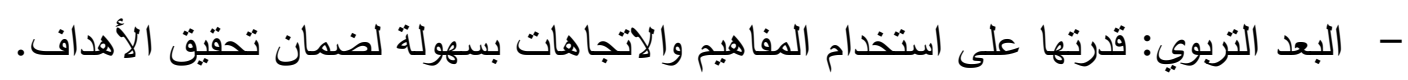
- البعد السلوكي: السلوكيات الأدائية التي تمكنها من إحداث تغيير في سلوكيات المتعلمين

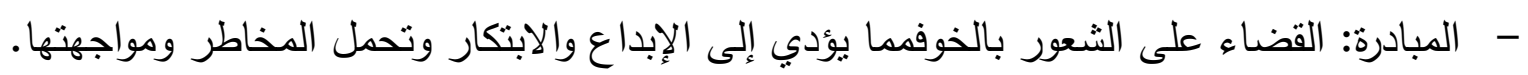
- الابتكار :من الركائز والعناصر المهمة في إدارة الأعمال مع الاحتفاظ بقوتها وتأثنيرها.

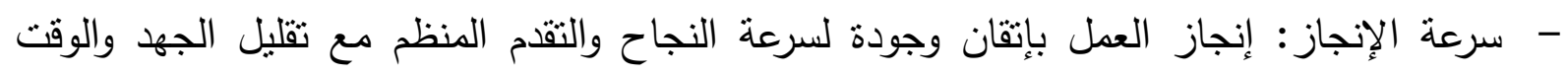
والمال.

- التمكين: إعطاء العاملين الصلاحيات الحرة في أداء العمل دون تدخل مباشر من الإدارة الخاصة بالعمل. - الذكاء العاطفي: قدرة الفرد على مواجهة أعباء الحياة والتعامل وإقامة علاقات اجتماعية، وينطلب

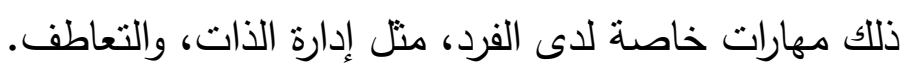

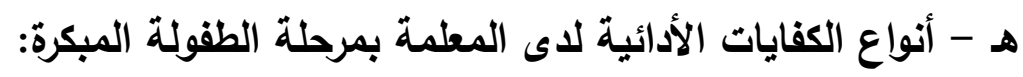

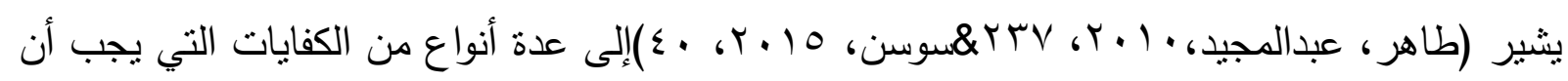

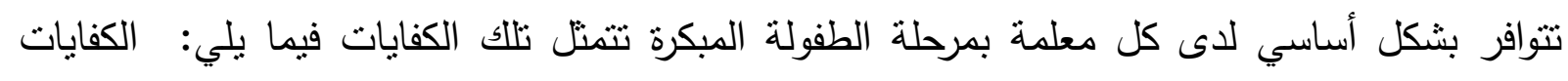

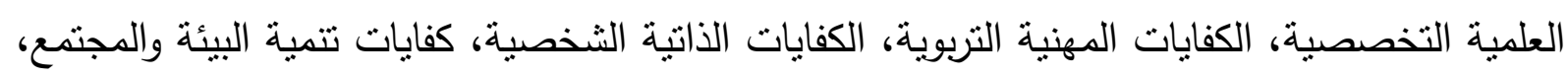
الكفايات الأخلاقية والاجتماعية والأكاديمية والتنربوية والسلوكية.

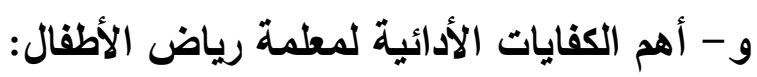

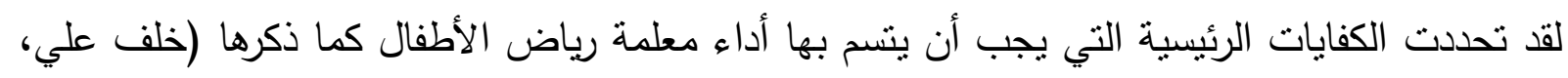

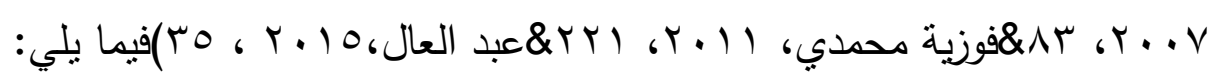
أخلاقيات تلتزم بها المعلمة:محبة للأطفالوتتجعهم على التعاون.

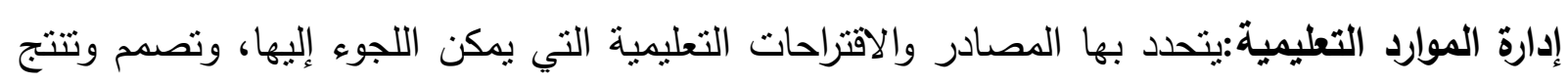
مواد تعليمية تفيد الأطفال داخل قاعة النشاط، فهي تبتكر وتراعى الفروق الفردية فيما بينهم. 
الممارسة الموجهة:تتعامل فيها المعلمة بحكمة وترى مدى تفاعل واستجابة الأطفال ثم ثقيم النتائج وتحاول تتمية مهارة الطفل العقلية، وتتجعهم على روح التعلم التعاوني. التوجية: توجيه خطوات العمل واكتثاف مدى فهم الأطفال واستيعابهم، وملاحظتهم داخل قاعة التها النشاط وتقدم لهم التخذية الراجعة. التخطيط والإعداد: التخطيط لتتمية مهارات الأطفال مع تحديد الأهداف والأنشطة المناسبة داخل القاعة

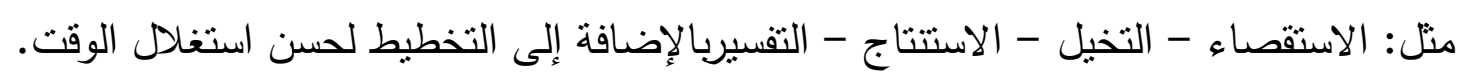
التقويم المكتوب:تقويم عمل الأطفال كتابة بحيث يمكن الرجوع إليه عند الحاجة.

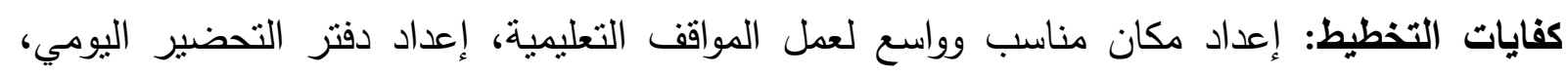
مراعاة الفروق الفردية بين التلاميذ عند اختيار المادة العلمية.

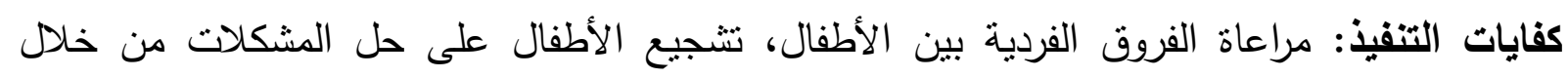

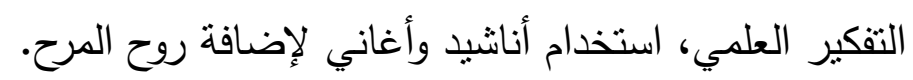

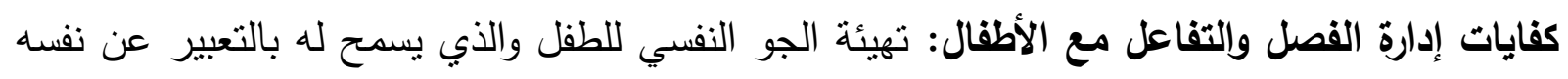

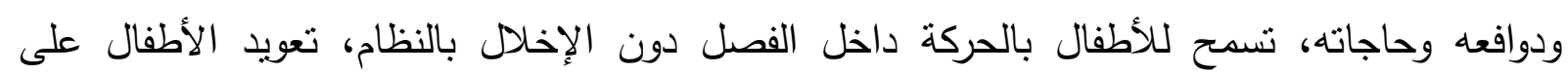

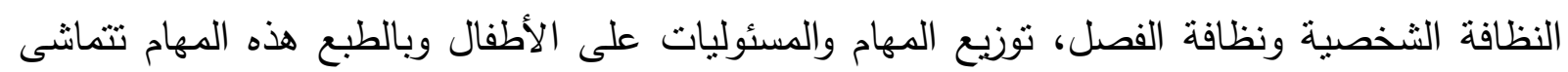

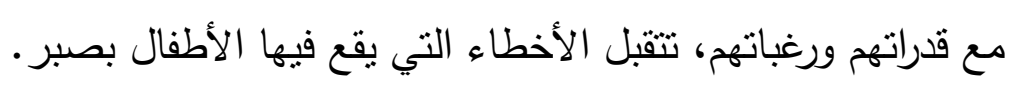
كفايات الإعداد للأنثطة اللاصفية: الكتب والمطبخ والرسم، وهي تتيح للأطفال أن ينتجوا ومن ثم يتحملوا المسئولية، وتوزيع المهام على حسب العمل الجماعي. كفاية تنمية المجتمع:القدرة على غرس الأخلاق والقيم داخل كل طفل، حتى ينشأ الطفل قادرة على حب الوطن والمجتمع ككل. كفاية التنمية الثاملة للأطفال:تتمية الطفل تتمية شاملة من خلال توافر المناخ النفسي الذي يشبع حاجات الطفل، ويشعرهبالثقة في نفسه، ويعطيه الثعور بالأمان، وإثباع احتباجاته الجسدية والعقلية.

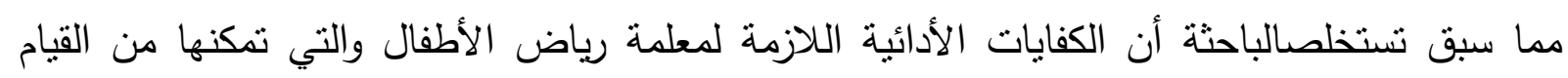
بدورها وإنجاز مهامهاما يلي: تصني - غرس القيم والأخلاق الحميدة في نفوس الأطفال من خلال الأعمال والأفعال أمامهر. - صياغة أهداف خاصة بالنشاط وتجعل الأطفال يشتركون في صياغة هذه الأهداف وكنلك تصميم وسائل تعليمية تتتاسب مع أهداف الدرس.

- التتويع في الأنشطة التعليمية لإثارة الطفل ومن ثم تحقيق أهداف العملية التعليمية.

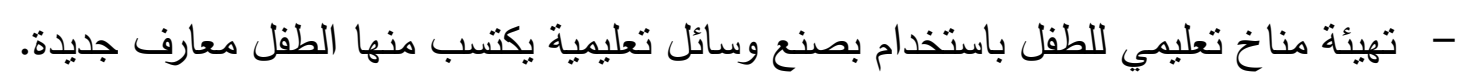
- - تحقيق النمو الكامل للطفل من جميع الجوانب والتي تجعل من الطفل شخصاً واثقا متفاعلاً مع المجتمع. 
- الاهتمام بالأطفال واقامة العلاقات الدافئة القائمة على الاحترام المتبادل معهم، ومراعاة الفروق الفردية بين الأطفال.

- قدرة المعلمة على تعليم الأطفال بشكل مباشر من خلال جذب اهتمامهم باستخدام الوسائل التعليمية

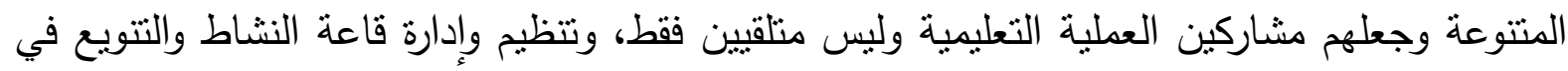
أساليب التواصل مع الأطفال. - القدرة على تقويم أداء الأطفال بعد تقييمه، وإعطاء وصف واضح لأدائهم وتفسيره، وذلك في ضوء أهداف المنهج. ولما كان نجاح المعلمه في تحقيق أدوارها يرتبط بقدرتها علي إكتساب المهارات والكفايات التي أفرزها

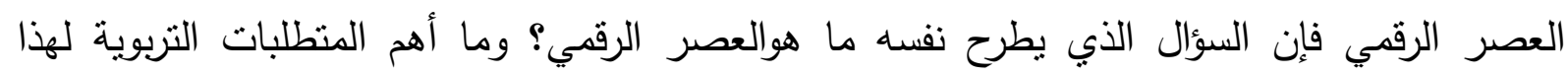

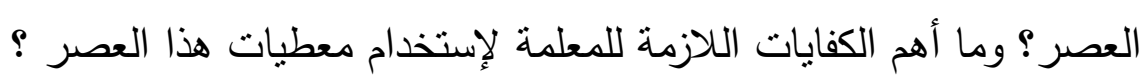
المحور الثاني: العصر الرقمي: لقد احدث العصر الرقمي ثورة في التعليم حيث مكنت تقنيات هذا العصر الطلاب من أن يصبحوا أكثر نشاطاً وأكثر استقلالية في تعلمهم، فالإنترنت سمح بإقامة تجمعات ذات فات بنى معرفية جديدة بمكن فيها

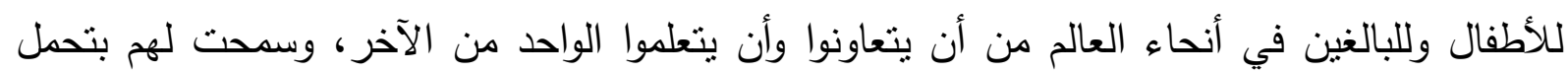

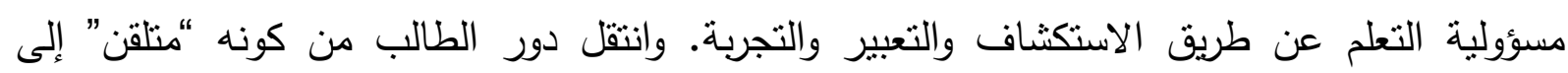

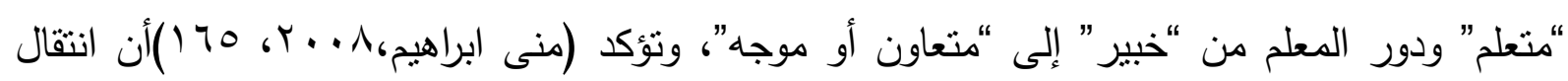

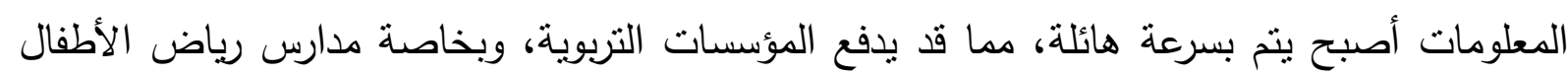

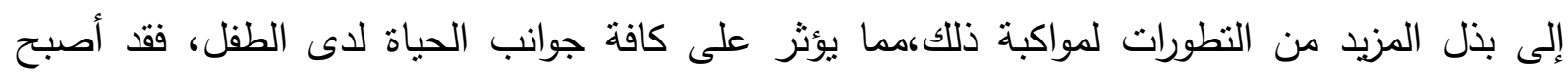
التدريب على استخدام تكنولوجيا المعلومات مطلب هام، لكي تزداد ثقة ومعرفة المعلمين، بالإضافة الكانة لارتقاء مهاراتهم في استخدام أدوات تكنولوجيا المعلومات، لذلك ليس غريباً التما توصلت إليه الدراسات

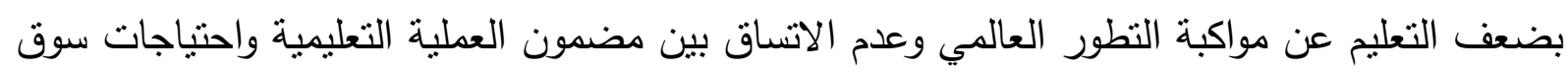

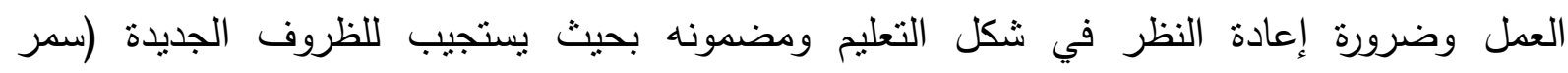

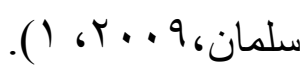

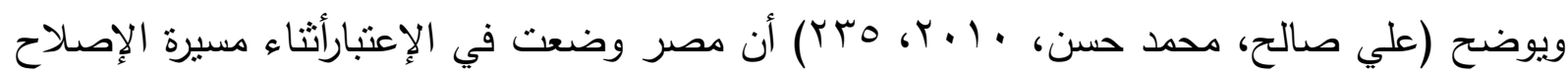

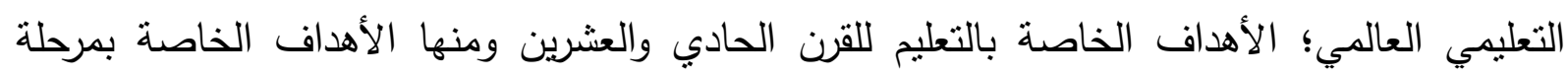
الطفولة المبكرة، وتمثلت في؛ الألئ

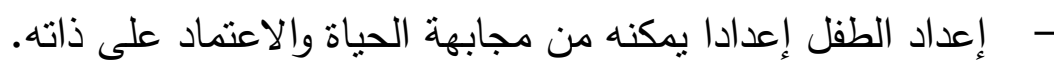

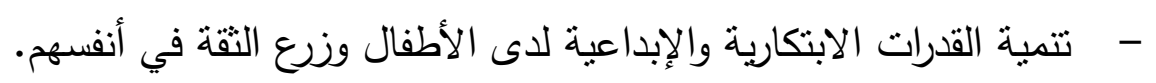
- - - توفير الييئة المادية والبيئة المعنوية المدعمة لنمو الأطفال نموا سليما.

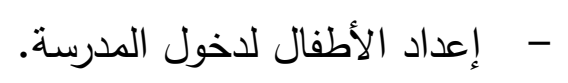


- - تدعيم خبرات الأطفال وتهذيب سلوكياتهم وتأهيلهم للتكيف مع المحيطين بهم

وتعد جودة التعليم قضية مهمة لدى الدول المتطورة والنامية على حد سواء، لزيادة فاعليةالتعليم وتحسين نوعيتة، وتجوبد مخرجات المؤسسات التربوية المتمتلة في نواتج التعلم، استتادا لمعايير ومستويات واضحة ومحددة تلبية لمتطلبات القرن الحادي والعشرين ومواجهة تحدياتههونظرا لأن التربية المعاصرة تتجه بقوة نحو الأخذ بمستجدات عصر العولمة والرقمنة، فقد أصبح من الضروري التصدي للعديد من الجوانب ذات العلاقة بأنماط التعليم التي تنتهدف تطوير مهارات استخدام التقنيات لدى المعلم والمتعلم على منى

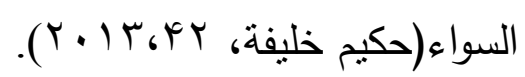

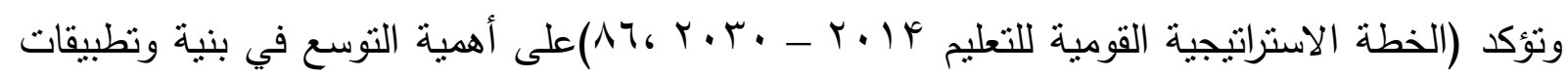
والاستفادة من تكنولوجيا المعلومات في الممارسات التربوية والإدارية بمختلف مستويات منظومة التربية والتعليم لضمان تأهيل الأطفال الاقتصاد المعرفة مع كفاءة وفاعلية إدارة المنظومة في إطار القيم الرقمية وخدمات الحكومة الإلكترونية.

\section{أولا: مفهوم العصر الرقمي:}

تعد مرحلة عصر المعلومات أو العصر الرقمي أحدث ما عاشته البشرية من نطور، وذلك بداية من النصف الثاني من القرن العشرين حتى اليوم الحالي، وهي الفترة التي يعتمد المجتمع للتطور فيها على

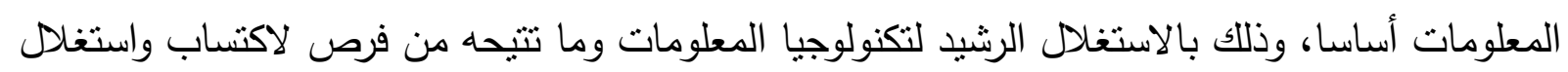

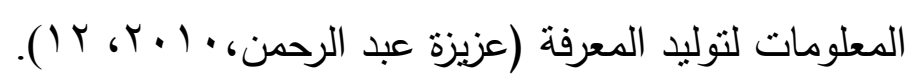
ونظراً لقلة التعريفات التي تناولت العصر الرقي وتباينها فإننا نورد منها ما يلي: عرفه (حسين،ی . . r، (T)بأنه: الدراسة النظرية والتطبيقية لكافة الجوانب التقنية والإنسانية لمفاهيم المعلومات، ووسائل تشغيلها وإنتاجها، بما بتضمنه ذلك من بنية وتركيب وخصائص المعلومات والاتصالات، وطرق نقل المعلومات وتتظيمها وتخزينها واسترجاعها، من خلال توظيف تكنولوجيا المعلومات من اتصالات وأقمار صناعية وشبكات معلومات وكمبيوتز وبرمجيات، وكل المستحدثات التكنولوجية التي تمثل مصدرا للمعلومات. كما يعرف العصر الرقمي بأنها الاستخدام المتعدد للأبعاد التكنولوجية لدعم اكتثاف المعرفة مما يساعد Ozhan في صناعة القرار ، وتتضمن طريقة جمع البيانات وتتظيمها وتحليلها وتمثيلها وتصنيفها وإدارتها. (Tingoy\& Sabri Serkan, 2011, 222)

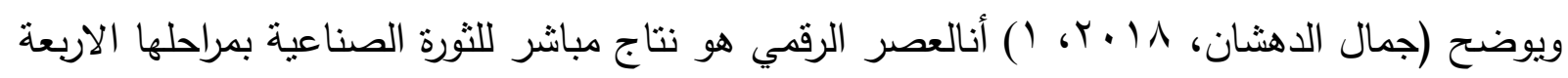
الثورة الصناعية الأولي البخار، الثورة الصناعية الثانية الكهرباء، الثورة الصناعية الثالثة الإكترونيات، الثورة الصناعية الرابعة الرقمنة وتعرف الباحثة العصر الرقميبالنسبةلمعلمة الطفولة المبكرة بأنه قدرتها على تحديد احتياجاتها من المعلومات، والتعامل مع المصادر الإكترونية وخاصة الكمبيونز والانترنت في الحصول عليها والتعامل بله 
معها وتتظيمها بما يحقق أهدافها، وانتقاء المناسب منها، بالإضافة لتطويعها، ومزجها بالتطبيق العملي وابتكارها.

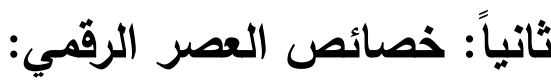

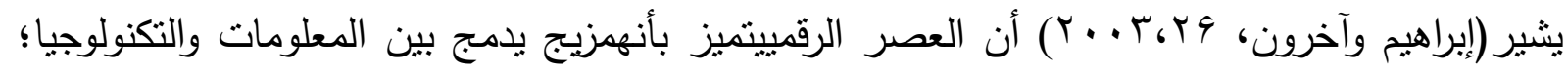

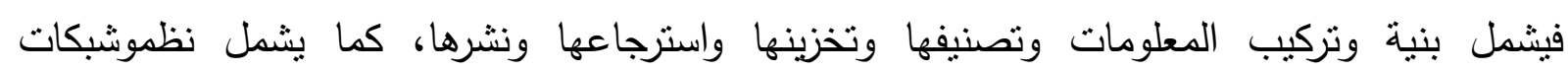

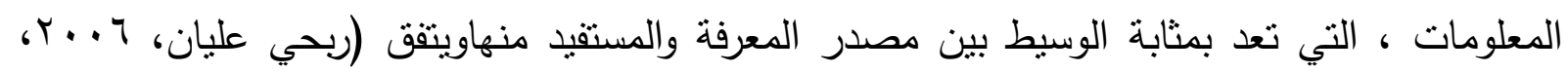
(Afgan, NaimH \& carvalho, Maria G, 2010, \&Makinen, Heikki, 2008, 2\& \ᄉ (32 على وجود إختلافات بين العصر الرقمي وعصر المعرفة حيث بمكن تحديدالفرق بين المعرفة والرقمنة

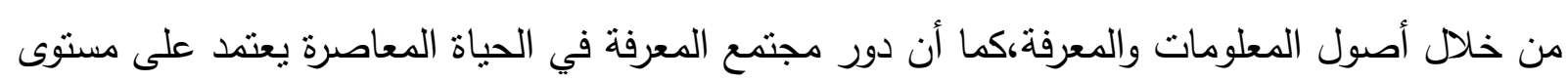

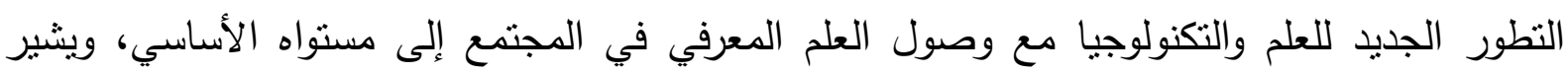

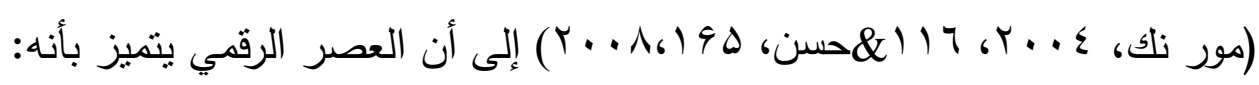

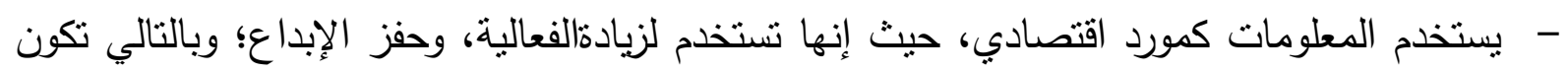
ذات منفعةالاقتصاد الدولة بشكل كلي.

- - يستخدم الأفراد المعلومات كمواطنين لممارسة حقوقهم ومسئولياتهم المدنية. - - - هناكتطوير لنظم المعلومات التي ستوسع من توصل الجمهور للمعلومات التربوية والثقافية.

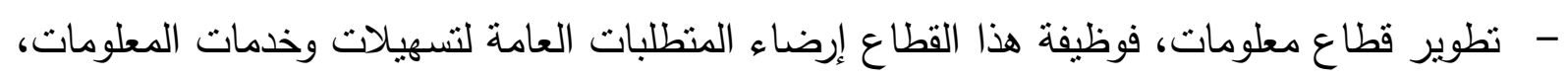
وجزء عام من هذا القطاع هو الذي يعتني بالبنيات التكنولوجية الأساسية.

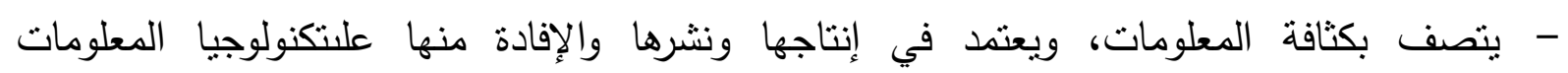
والاتصالات، ويضم كوادر بشرية تعمل على نتمية قطاعاته الاقتصادية والاجتماعية والسياسية ولثية والثقافية. - تمثل المعلومات القوة الدافعة والمسيطرة، ينشغل معظم أفراده، بإنتاجالمعلومات وجمعها ومعالجتها ونشرها.

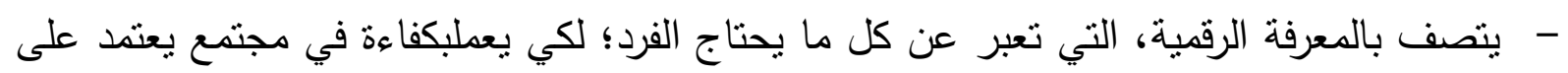

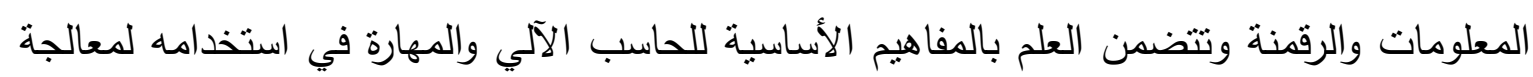

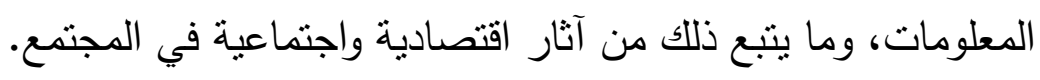

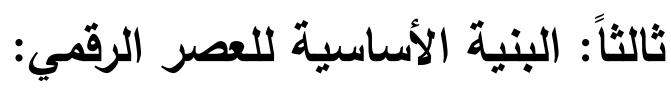

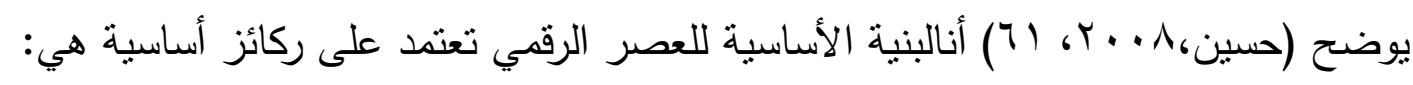

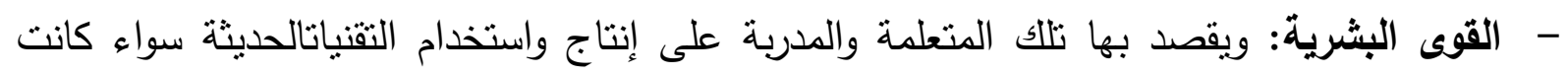

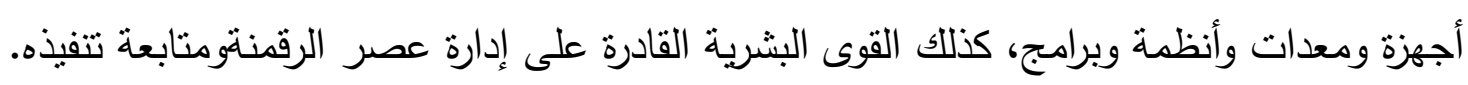
- المكونات المادية: الأجزة والوحدات الرئيسية والمساعدة وأجزائها المكونة لهاومكوناتها. 
- المعرفيات: يقصد بها الوسائل والأساليب المختلفة لتشغيل المعرفة وتمثيلها وعرضها، ويشملها برامج الحاسب وأنظمتها المختلفة سواء تطبيقية أو تشغيلية. - الإداريات: ويقصد بها مجموعة السياسات والقوانين واللوائح والتتظيمات المنسقة التي تساعده في أداء الدور المنوط به مع تذليلالعقبات التي تعترضه.

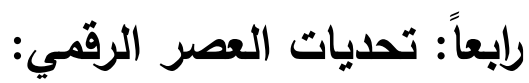

إن حركة العولمة والنطور التقني المنزايد تشكل في مجملها القوى الدافعة الأساسية لحركة التطوير التربوي فتقرض على الحكومات جملة من الأعمال التطويرية المحدة، ويظهر ذلك على صور إجرائية مختلفة

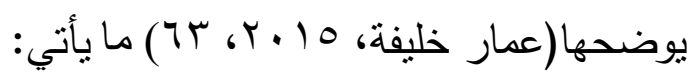
- - فرض تخصصات ومناهج محددة.

- - وضع تشريعات تضمن مشاركة المجتمع المحلي في رسم السياسة التعليميةللمؤسسات التربوية. - الاهتمام بالنواتج التعليمية ومخرجات منظومة التعليم والتنافس في مجال نوعية التعليم وتسويق ونشر

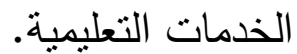

- الاهتمامبمهارات استخدام الحاسب والمهارات التقنية وفن التفكيروالقدراتالإبداعية والإدارة الذاتية فقد أصبحت من المهارات الأساسية اللازمة لمحو الأمية التكنولوجية . - - الانتقاللتعمل التشاركي لرفع وزيادة فعالية التعليم. - - اعتماد مبدأ اللامركزية الإدارية في العمل. - - تحول الاقتصاد من المحلية إلى العالمية. خامساً: مهارات العصر الرقمي: لقد أصبح انفجار المعلومات مشكلة حقيقية تواجه البشرية، وذلك بسببالزيادة المستمرة في الإنتاج الفكري، وتزايد الموضوعات العلمية، وظهور تخصصات دقيقة في مجالات المعرفة، بالإضافة لتتوع اللغات التي تتشر بها وتتوع مصادر المعلومات وتعدد أشكالها، وهذا الكم الهائل المتدفق من المعلومات يحتاج إلى تتظيم سريع ومستمر لاستخدامه واستثماره. ويعرف(أسامة محمد، ه . . مV مهارات العصر الرقميبأنها: "مجموعة المهارات المتعلقة بالمجالات المعرفية بمختلف المجالات والإجراءات الإدارية والتقنيات المختلفة المستخدمة، والجهود المبذولة في جمع المعلومات وتخزينها ونقلها ونشرها واسترجاعها، وما ينشأ من تفاعلات بين التقنيات والمعارف والإنسان بحواسه وإدراكاته".

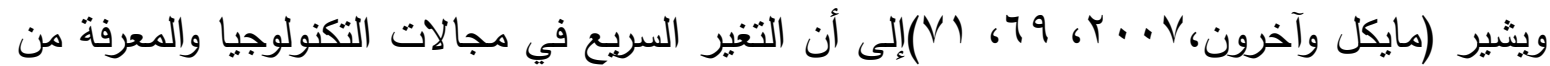
أهم سمات العصر ، وهذ أمر يفرض إكساب المتعلم القدرة على التعليم ذاتية مدى الحياة، ويمكن تصنيف مهارات العصر الرقمي إلى نوعين، الأولى تتعلق بالمهارات الخاصة باستخدام البرامج، والثانية الخاصة 
أولا: المهارات الخاصة باستخدام البرامج: وتتضح المهارات الخاصة باستخدام كل من:

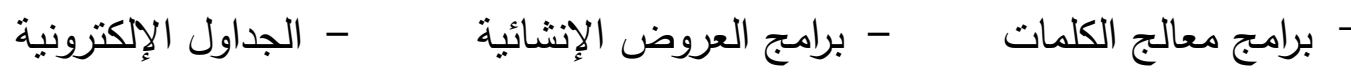

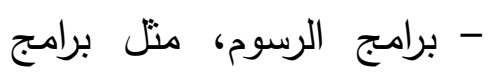
إنشاء الصور النقطية، برامج لبرج إنشاء الصور

$$
\text { - } \text { - قواعد البيانات }
$$

$$
\text { والمجموعاتالإخباريةوالدردشة }
$$$$
\text { - شبكة المعلوماتالدولية - برامج إنشاء الوسائط المتعددة }
$$

ثانيا: مهارات خاصة باستخدام الأجهزة: تتضح المهارات الخاصة باستخدام الوسائلة كل من:

$$
\text { - }
$$

وتلخص الباحثة قرة مهارات العصر الرقميفي مساعدة المعلمين على:

- - الوصول للمصادر الأولية للبيانات - - إعداد المواد التعليمية

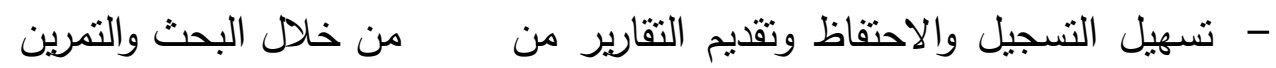
خلا ل الحفظ، والتجديد اليومي للحفظ؛ - تعليم التجارب والدفاهيم باستخدام

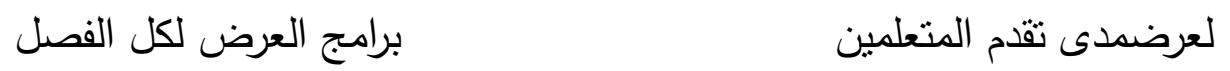

أهداف استخدام مهارات العصر الرقمي في منظومة التعليم:

ألقت ثورة المعلومات الضوء على أهمية تتمية العنصر البشري، وأكدت أهمية التعليم وآثاره على التتمية

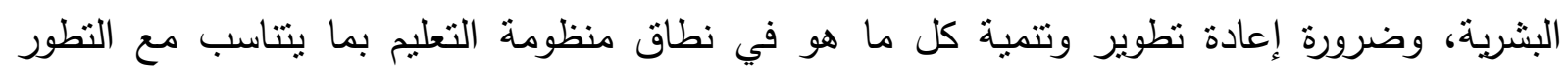

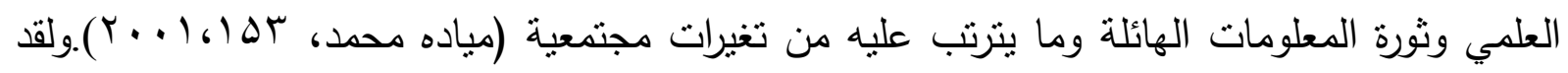

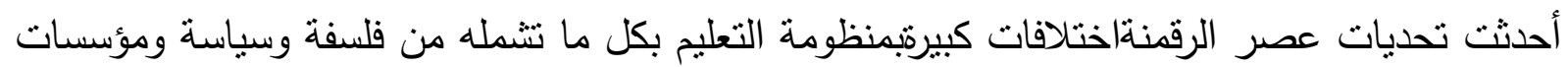

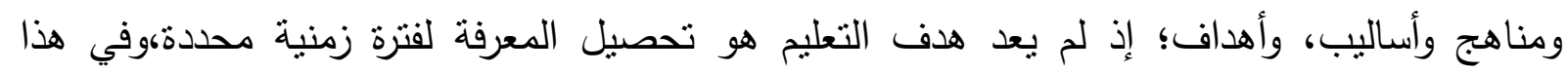

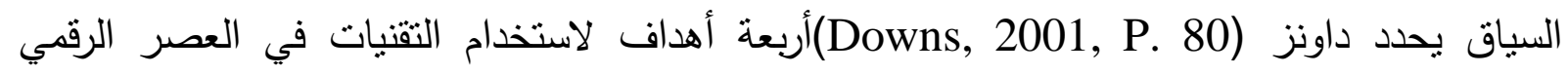
وقسمها إلى أربعة مستويات في التعليم تتشمل:تشجيع اكتساب مهارات تقنيات المعلومات كغاية بذاتها،

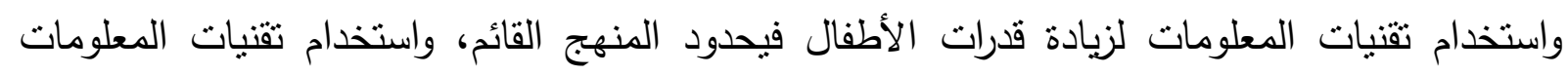

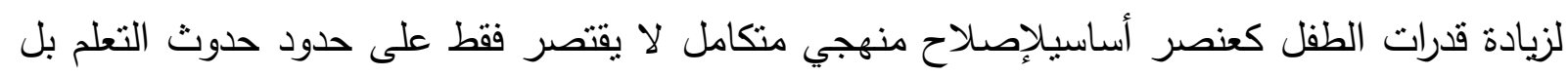

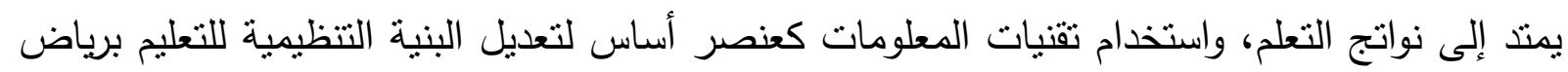

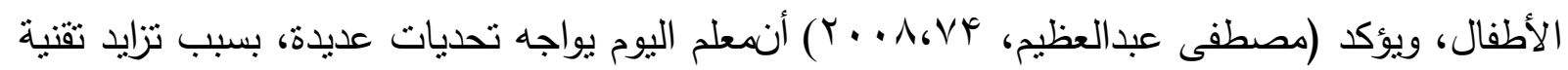
المعلومات كأداة داعمة لمنظومة التعليم، الأمر الذي فرض عليه الأليه اكتسابأكبر قدرمن المعرفة بهذه التقنية

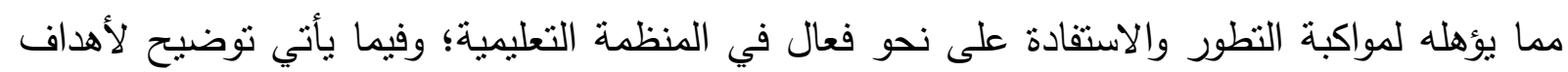

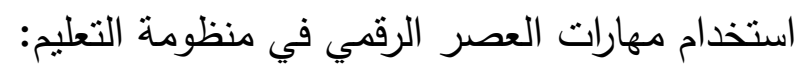


- الرقمنةوالاتصالات كهدف:إكساب المتعلم مهارات المعلوماتية كهدف في حد ذاته، لإعدادهم لاستخدام مهارات المعلومانية للعمل المستقبلي وللحياة الاجتماعية.

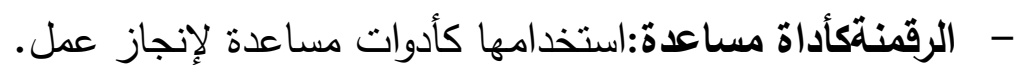
- الرقمنةكوسيط للتعليم والتعلم:استخدام مهارات المعلوماتية كوسيلة للتعليم والتعلم في حد ذاتها، والتي يمكن من خلالها للمعلم أن يعلم، والطلاب أن يتعلموا وذلك باستخدام صور مختلفه منها. - الرقمنة والاتصالات كأداة للتنظيم والإدارة داخل الروضة:استخدام مهارات الرقمنة كأداة من أدوات التظظيم والإدارة داخل الروضة التي تعتمد على التكنولوجيا الرقمية في التواصل مع المجتمع الداخلي بالروضة والمجتمع الخارجي، من أجل تحقيق أقصى استفادة ممكنة وفي أقل زمن ممكن. مهارات المعلم في ظل العصرالرقمي: بروب: إن استخدام التكنولوجيا الجديدة في التعليم تتطلب مجموعة من المهارات التي ينبغي أن تمتلكها

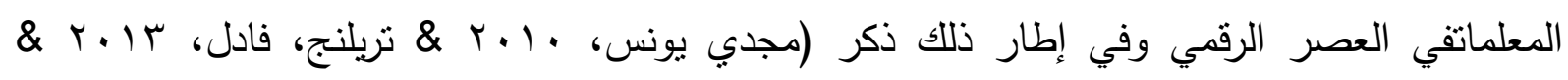

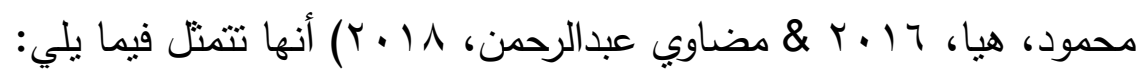
تنمية المهارات العليا للتفكير والقدرة على التفكير الناقد:يمثل إعداد المتعلمين وفقا لمهارات التفكير الناقد أحد المهام الأساسية لتربية العصر الرقمي، الأمر الذي يتطلب من المعلمة القيام بمجموعة من الممارسات لغرس وتتمية مهارة التفكير الناقد لدى طلابه، منها: التخطيط للمواقف والخبرات التعليمية حيث يعد المعلم مخطط الخبرات التعليمية نحو مشكلات الحياة الواقعية، من خلال التعامل على نحو إبداعي مع مواقف واقعية في حياة الطلبة. إكساب الطلاب المهارات الحياتية:يُعد تعليم المهارات الحياتية من الأهداف الرئيسة للتربية المعاصرة، ومن المهام الجديدة للمعلم في القرن الحدي والعشرين، حيث تركز المنظمات الدولية والإقليمية في السنوات الأخيرة، اهتمامها الثديد على "ضرورة تعليم هذه المهارات، وإدماجها في المناهج الدراسية وبرامج نكوين المعلمين. استخدام وإدارة تكنولوجيا التعليم:أصبحت التقنية مع التعليم من أهم المتغيرات التي تؤثر في رسم خصائص جيل المستقبل وفق آمال الفرد والمجتمع وطموحاتهما وتطلعاتهما، فالتعليم والتقنية هما طريق كمي المستقبل، وقد ظهرت بعض بوادر النغيير في كثثر من النظم التعليمية؛ حيث بدأت التقنية في العمل على إعادة تشكيل بيئات التعلم؛ وإحداث تغييرات جوهرية في علاقة المتعلم بالمعلم والمنهج، وفي آلية الاتصال وتبادل المعلومات بينها، وفي كيفية حدوث عمليتي التعليم والتعلم باتجاه النتاج المرغوب فيه. أدوار المعلم والمتعلم في العصر الرقمي: لا يمكن تجاهلالتطورات التي تحدث في الأنظمة التربوية العالمية من حوله، لذا لابد من إعداد المعلم المعاصر الذي يمتلك مهارات التفكير والقادر علنمواجهة التحديات التي تواجهه في العالم الرقمي المعقد دائم التغير، لاستمرار التتافسومواكبة عصر المعلومات والمهارات الرقمية والتكنولوجية الجديدة 


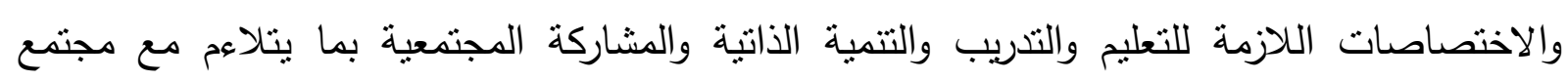

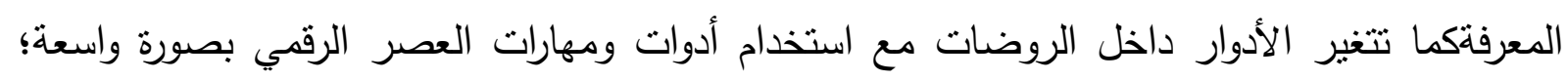

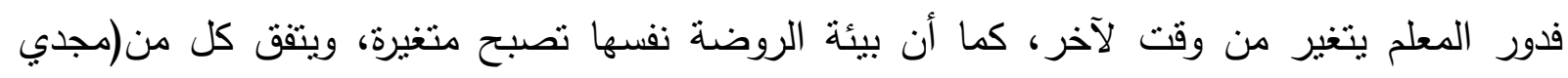

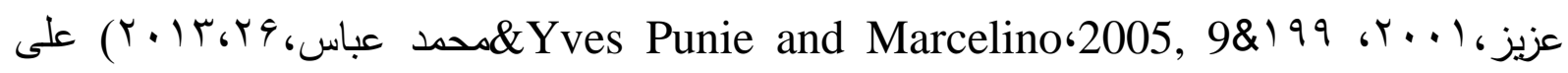
مجموعة من السمات التي يجب نوافرها في معلم العصر الرقمي منها: - أن يستجيب للمستحدثانالتكنولوجيةويتفاعل معها ليطور من أساليبه التنريسية.

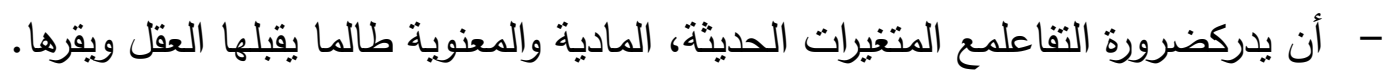

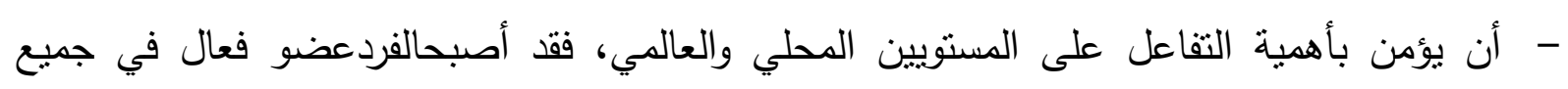
الأحداث التي يمربها العالم اليوم. - - غرس حب الوطن والانتماء إليه لاى أطفاله، فتلك القيم من أهم القيم التي تبث في الأطفال، وترسخ

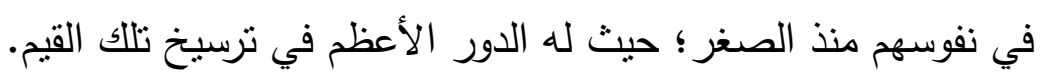
- - إكساب الطفل لغة الحوار فذللك من الجوانبالمهمة في دور المعلم، فيدرب الطفل على على استخدام

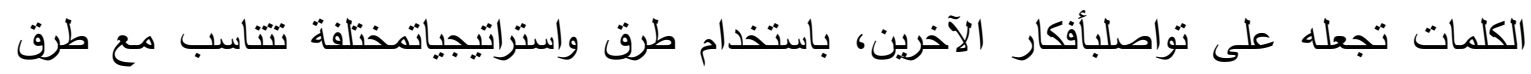
التواصل داخل العصر الرقمي. - - ربط الروضة بالمجتمع: فالمجتمع هو الفلسفة التي تنبعليها المناهج، فالروضة مؤسسة اجتماعية

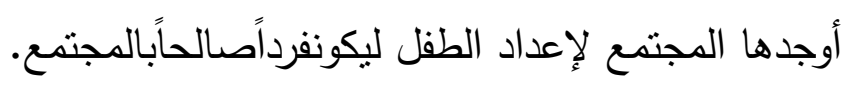

الأدوار الجديدة للمعلم في العصر الرقمي:

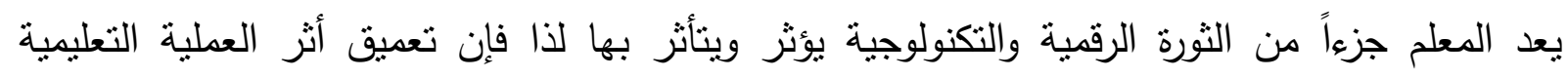

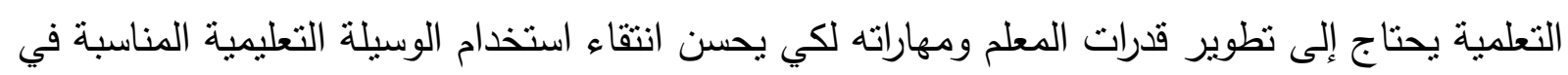

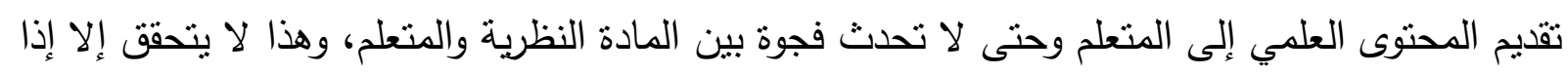

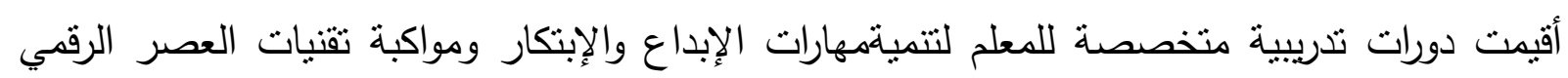

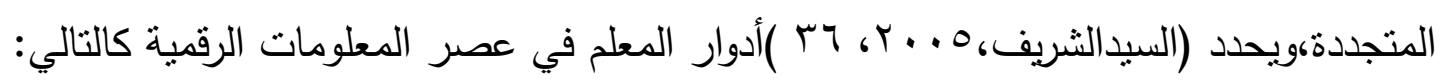
- باحث:يبحث عن كل جديد ومتعلق بالطفل، وابتكار طرق متميزة في تقديم الأنشطة.

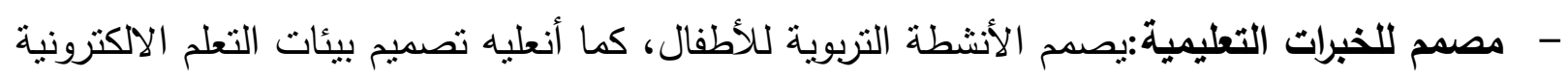
النشطة بما يناسب مستويات واهتمامات الأطفال. - تكنولوجي:يتقن مهارات تمكنه من استخدام الثبكات في عملية التعلم، كلغة البرمجة، وبرامج تصفح شبكة الانترنت، واستخدام برامج حماية الأجهزة والملفات. - مقدم محتوى: تقديم المحتوى في العصر الرقمي من خلال الموقع التعليمي لا بد من أن يتميز بسهولة الوصول إليه واسترجاعه والتعامل معنه. 
- مرثد وميسر للعمليات:فدور المعلم الأكبر هو تسهيل الوصول للمعلومة، وتوجيه وإرشاد الأطفال أثناء تعاملهم مع الوسائط التكنولوجية. - مقوم:يعمل على تقويم الأطفالويمنلك القدرة على تحديد نقاط القوة والضعف لديهم، ومن ثم تحديد البرامج الإثرائية والعلاجية المناسبة. - قائد للعملية التعليمية:في مستوى متقدم يصبح مديراً وقائداً للتعلم عبر الانترنت بعد تدريب الأطفال على استخدام تلك التقنية سواء المتزامن أو غير المتزامن.

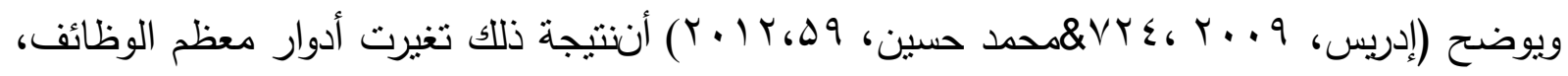

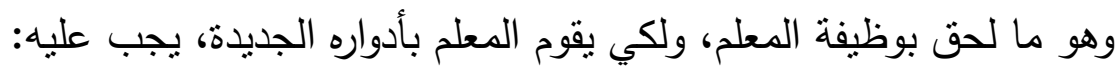

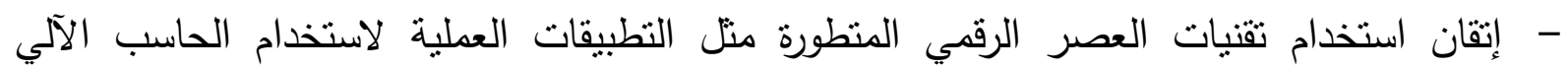
وشبكات المعلومات وقواعد البيانات، ومختلف الوسائط المتعددة. - - التمكن من توفير التدريبات المصورة واللفظية في حل المشكلات العلمية والتعليمية. - - تحديد مصادر المعرفة التي تتيحها شبكة الانترنت للبحث عنالمعلومات المستهدفة. - - امتلاك مرونة التفكير التي تسمح له بتقبل الجديد مهم ومفيد لإثراء المنظومة التعليمية. - تدريب الطفل على التعلم الذاتي المستمر مدى الحياة لتحقيق مبدأ التتمية المستدامة. - - التمكن من صياغة أسئلة تتمي مهارات التفكير الابتكاري والإبداعي والناقد لدى الأطفال. - - إتقان إعداد وسائل تتمية حب الاسنطلاع في نفوس الأطفال.

الأدوار الجديدة للمتعلم نتيجة استخدام مهارات العصر الرقمي:نتيجة لتغير أدوار المعلم، فقد

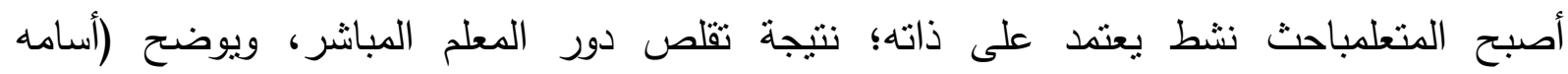

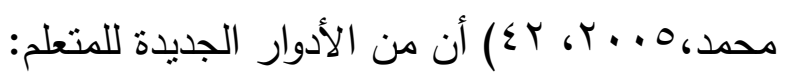
- - كمعلم: بتتمية قدرته على استخدام تكنولوجيا المعلومات ونقلها لقرنائه داخل قاعة النشاط.

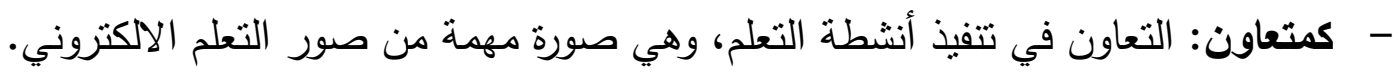
- كمساعد مدير : المتعلمون ينعاونون في العمل كفريق، فهناك العديدمن الأدوارفي التعلم التعاوني مثل من فئل

$$
\text { (المسجل - الوسيط - الخبير - القائد - الحافظ). }
$$

\section{المتطلبات التريوية والتعليمية الضرورية للمعلمة والطقل فيالعصر الرقمي :} إن الدور الذي تقوم به مؤسسات التربية للطفولة المبكرة في تثكيل شخصية الطفل، وتحقيق تكيفه مع التعبه

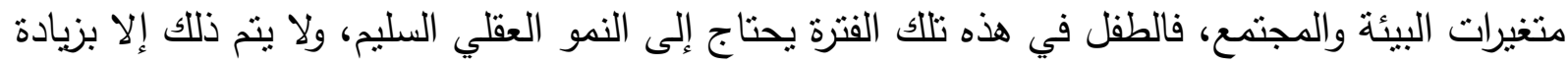

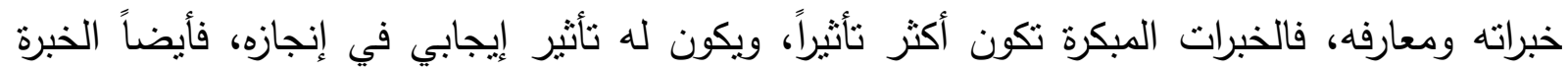

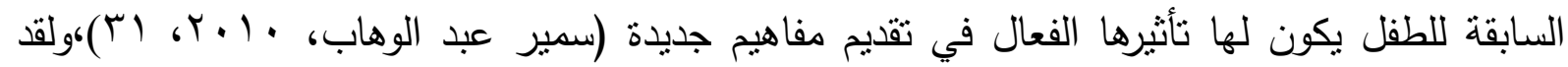

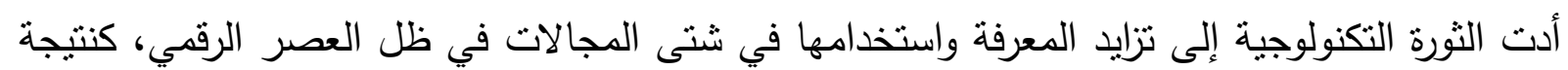

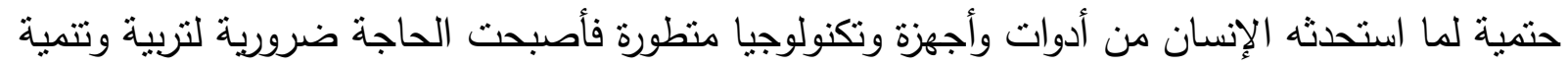


العقل الواعي المنتجالمفكر والقادر على مواجهة التحديات العالمية في شتى شئون الحياة (هناء علي،

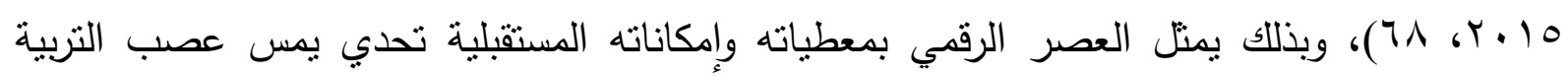

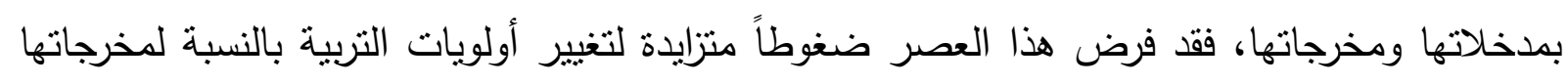

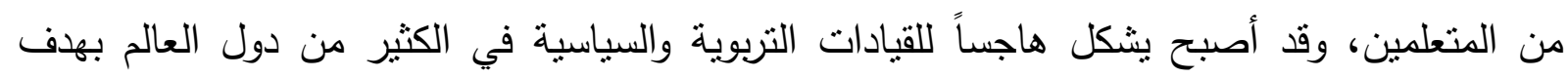

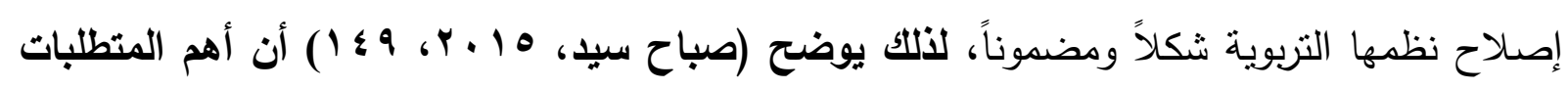
التعليمية للعصر الرقمي فيما يأتي:

- إقامة نظام تعليمي يد يواكب

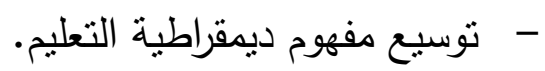
- الإفادة من نوظيف التكنولوجيا المتطورة في التغيرات المعرفية.

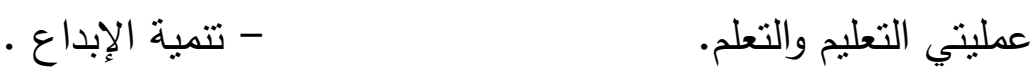

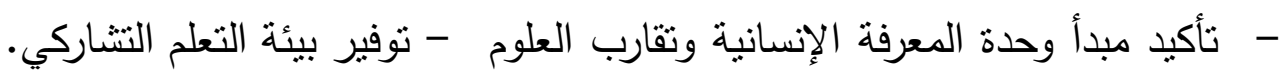
- العمل على نشر ثقافة التتمية المهنية. وتكاملها. - التمكين الإداري للمؤسسات التعليمية. - - توسيع المدار الزماني والمكاني للتعليم والتعلم. - تلمان.

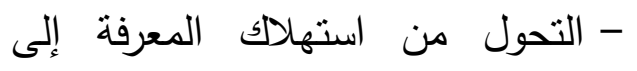
- - تحديث أنماط التعليم والتعلم. انتاجها.

أهم المتطلبات التريوية لطقل الروضة في العصر الرقمي:

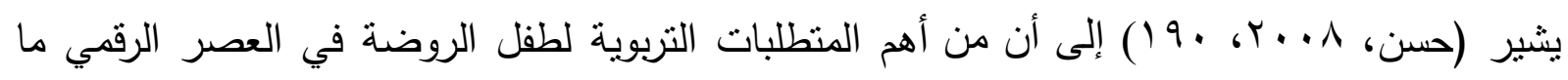
يأتي: - توفر مهارات تتعلق بالتكنولوجيا المتقدمة وبكيفية نوظيفهاوالاستفادة منها، أب ضرورة توفير التمكن الرقمبللمتعلم. - تتمية الإبداع والخيال لدى الطفل في العصر الرقمي، حيث الحصول على المعرفة والتفاعل معها

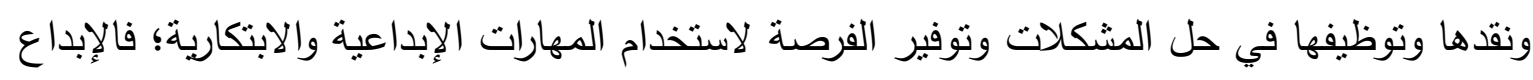

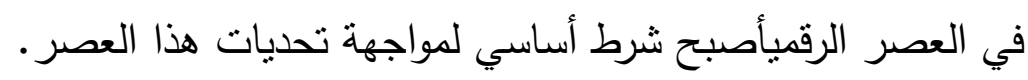

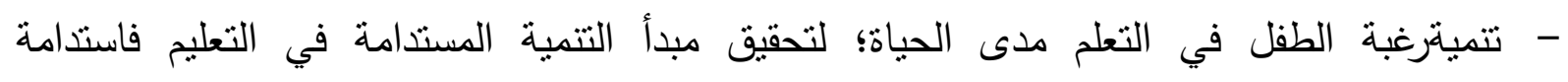

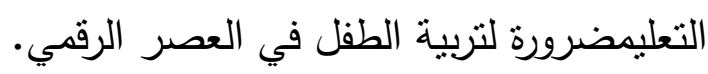
- - تتمية قدرة الطفل على إنتاجية المعرفة.

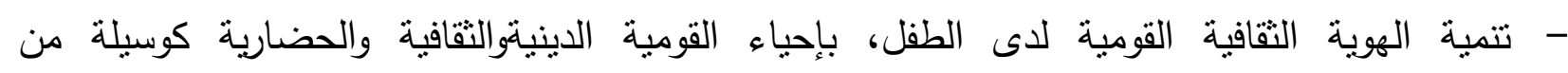

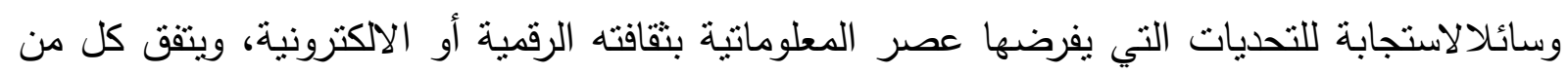

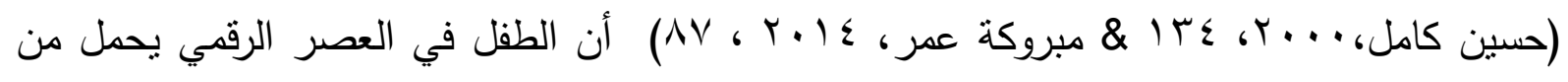

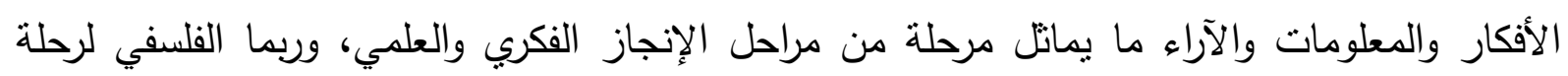

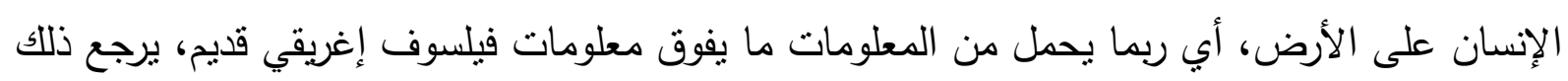


إلى كم المعلومات والمدركات من حوله، وكان لذلك انعكاسات عديدة على الطفل، منها الإيجابي متلنطور القدرات الذهنية والتعليمية لديه أكثر من أقرانه، تؤدي إلى رفع قدرة الطفل على القراءة والكتابة والتعبير الثففوي، والقدرة على الاستماع والتزكيز، وتعلم الثقافة العامة والعلوم واللغات الأجنبية، والتزبية الفنية والرياضيات، كما أنها تقوى القدرة على حل المشكلات التي تواجهه، وتساعده على التوافق الاجتماعي، وتطوير هواياته ومواهبه واستغلال وقت فراغه، والإنعكاساتالسلبية للعصر الرقمي؛ فاستخدام التكنولوجيا بصورتها الحالية لهالتأثير السلبي، حيث إنها تعمل على تدنيمستوى التفاعل الإجتماعي، وتحد من ممارسة الرياضة البدنية، وتتسبب في إصابته بالخمول والسمنة، وتدهور الصحة|لعامة، وقد تؤثر

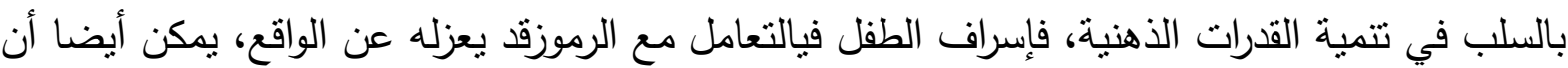
تؤدي لإعاقة القدرات الإبداعية، ويمكن أن تحد من قدرته على استخدام مهارات التواصل، ففي ظل الت التهن

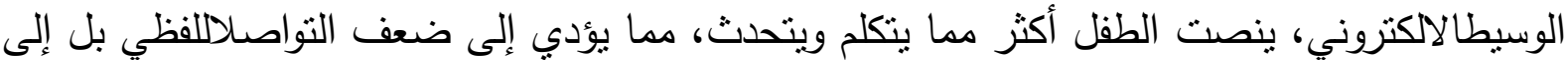
ضموره وتسطيحه.

\section{الكفايات اللازمة لمعلمات الطفولة المبكرةوفقاً لمتطلبات ومهارات العصر الرقمي:}

يعد قطاع التربية هو الأكثر حرصاً على الإفادة من الإمكانات التي توفرها تقنية المعلومات نظراً لحاجته

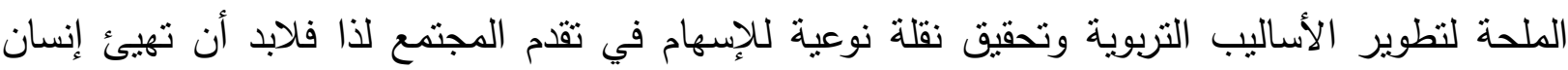

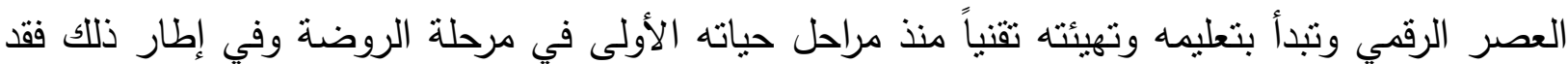

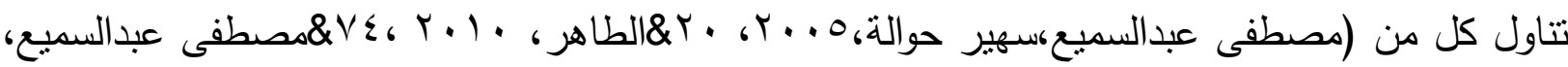

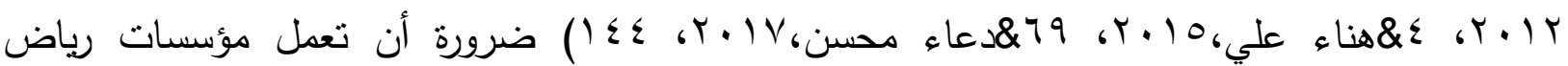
الأطفال على إعداد الأطفال القادرين على اكتساب وتحويل المعلومة لمعرفة قابلة للاستخدام، والتكيف والتعلم بسرعة، وامتلالك المهارات اللازمة لذلك، واتقان التعامل مع تكنولوجيا المعلومات، والتعاون والعمل ضمن

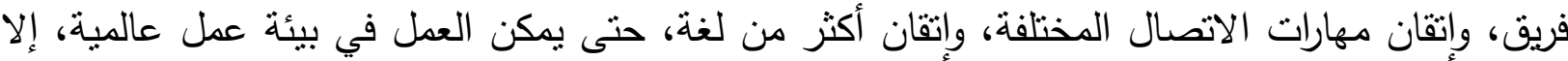
أنه لا تزال العديد من المعلمات في مرحلة الطفولة المبكرة يجهلن تلك المهارات إما لنقص التدريب أو إنعدمه

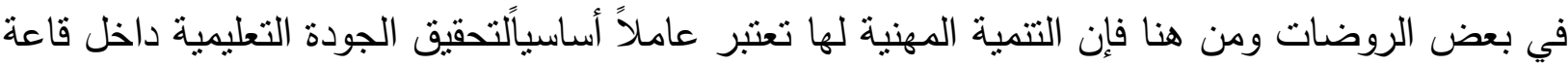

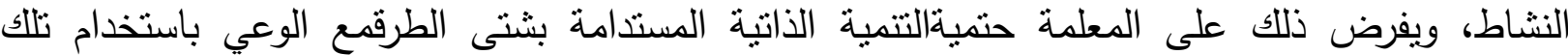

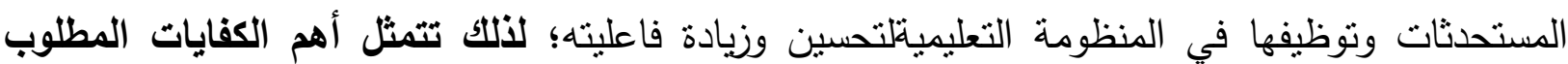
تحقيقها لإدماج متطلبات ومهارات العصر الرقمي في التعليم واستخدامها من خلال المطلمات في مرحلة

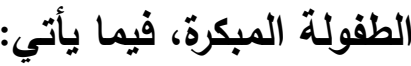
- كفايات تكنولوجية (كفاية شخصية):مثل فهم امكانات الوسائط وأدوات الاتصال بإيجابياتها ومعوقاتها، ويوجد مكونات ثلاثة حيوية لتحقيق الكفاية التكنولوجية للمعلمات وهي أن تستخدم التكنولوجيا: كأداة لتدعيم عمل المعلمة مع الطفل أو كأداة إنتاجية في ضبط العملية التعليمية، أو تحسين المعرفة المهنية المتخصصة للمعلم. 
- كفايات مبنية على فروع المعرفة (كفاية المادة العلمية):أي تحقيق الكفاية في تكامل مهارات العصر الرقمي مع المواد العلمية ، ومهارات تصميم المناهج، وفهم التعلم القائم على نظريات التعلم المختلفة؛ وتتنمل هذه الكفايات على:التقويم والتقييم للمصادر التعليمية المعتمدة على الكمبيوتر، واستخدام التكنولوجيا لنطوير مواد المنهج لتحقيق نتائج التعلم، واستخدامها لتوصيل المحتوى لتحقيق نتائج التعلم،

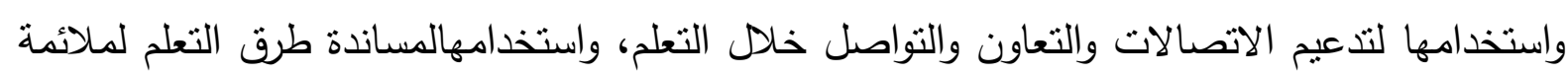

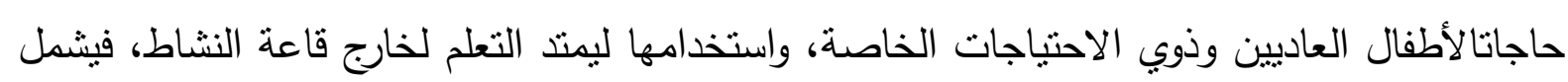

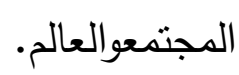
- الكفاية التتريسية:تحقيق الكفاية في الإعداد والتخطيط والتتفيذ والتقويم ، وإدارة المهارات المختلفة منل مهارته كميسر للحصول على المعلومات، وإدارة الوقت، وغيرها. - الكفايات التحليلية والتأملية:إندمج العصر الرقمي في التدريسيتطلب تتمية بعض الكفانس والكايات التحليلية منل

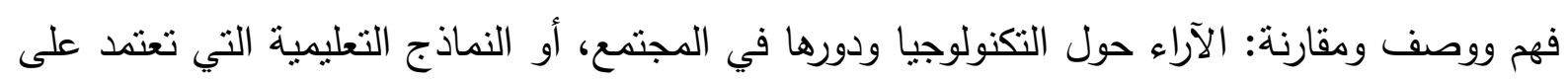

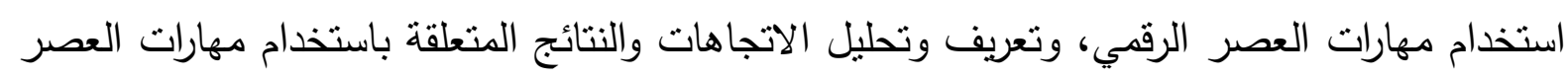

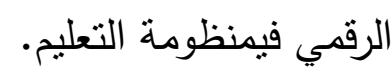

\section{الاراسة الميدانية:}

هدفها: تستمد الدراسة الميدانية أهدافها من أهداف البحث الحالي والتي تعنى بتطوير الكفايات الأدائية للمعلمات بمرحلة الطفولة المبكرة في ضوء متطلبات العصر الرقمي وذلك من خلال:

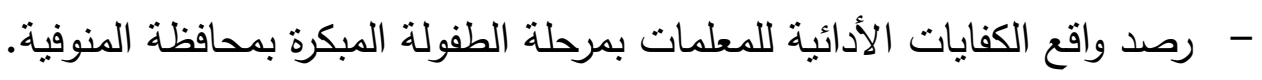

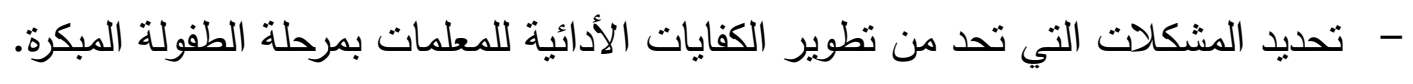
- - التوصل لآليات تطوير الكفايات الأدائية للمعلمات بمرحلة الطفولة المبكرة بمحافظة المنوفية.

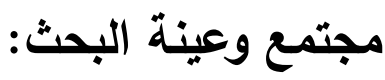
مجتمع البحث:تمتل فيمعلمات مرحلة الطفولة المبكرة بمحافظة المنوفية؛ وقد بلغ عددالمجتمع الأصلي

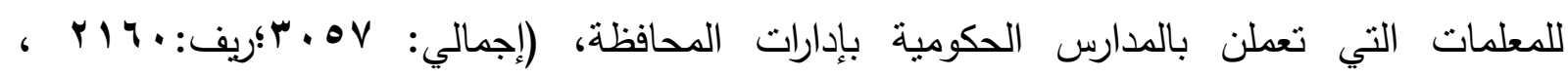

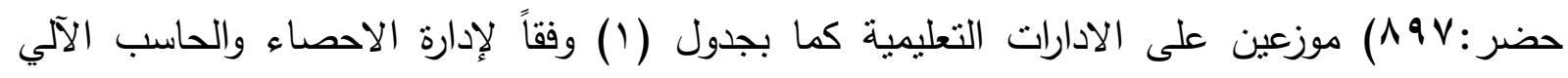

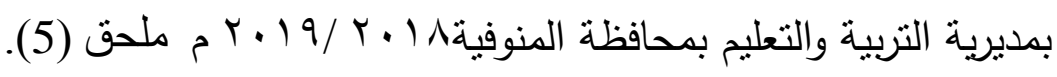




\section{جدول (1)}

يوضح الأعداد والنسب المئوية لـ (مجتمع وعينة الدراسة) من معلمات مرحلة الطفولة المبكرة بالمدارس الحكومية بالإدارات التعليمية بمحافظة المنوفية

\begin{tabular}{|c|c|c|c|c|c|}
\hline \multicolumn{2}{|c|}{ عينة الدراسة } & \multirow[b]{2}{*}{ البحث } & \multirow[b]{2}{*}{ ريف/حضر } & \multirow[b]{2}{*}{ الإدارة } & \multirow[b]{2}{*}{ r } \\
\hline 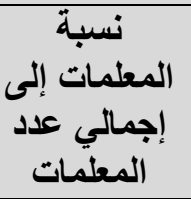 & المعلمات & & & & \\
\hline $27.20 \%$ & 55 & $r \leq \varepsilon$ & حضر & \multirow[t]{2}{*}{ شبين الكوم } & \multirow[t]{2}{*}{1} \\
\hline $13.06 \%$ & 35 & rAr & ريف & & \\
\hline $6.13 \%$ & 12 & 00 & حضر & \multirow[t]{2}{*}{ أشنمون } & \multirow[t]{2}{*}{ r } \\
\hline $20.65 \%$ & 56 & $\varepsilon \leqslant 7$ & ريف & & \\
\hline $9.92 \%$ & 20 & 19 & حضر & \multirow[t]{2}{*}{ منوف } & \multirow[t]{2}{*}{$r$} \\
\hline $12.82 \%$ & 34 & $Y V V$ & ريف & & \\
\hline $5.91 \%$ & 12 & or & حضر & \multirow[t]{2}{*}{ تلا } & \multirow[t]{2}{*}{$\varepsilon$} \\
\hline $7.82 \%$ & 21 & 179 & ريف & & \\
\hline $12.49 \%$ & 25 & $11 r$ & حضر & \multirow[t]{2}{*}{ قويسنا } & \multirow[t]{2}{*}{0} \\
\hline $15.09 \%$ & 41 & דr & ريف & & \\
\hline $8.25 \%$ & 17 & $V \varepsilon$ & حضر & \multirow[t]{2}{*}{ الباجور } & \multirow[t]{2}{*}{7} \\
\hline $10.32 \%$ & 28 & rTr & ريف & & \\
\hline $2.56 \%$ & 7 & rr & حضر & \multirow[t]{2}{*}{ الشهداء } & \multirow[t]{2}{*}{ v } \\
\hline $5.60 \%$ & 15 & ||$_{1}$ & ريف & & \\
\hline $5.13 \%$ & 10 & $\Sigma 7$ & حضر & \multirow[t]{2}{*}{ بركة السبع } & \multirow[t]{2}{*}{$\wedge$} \\
\hline $9.68 \%$ & 26 & $r \cdot q$ & ريف & & \\
\hline $7.58 \%$ & 15 & 71 & حضر & \multirow[t]{2}{*}{ سرس الليان } & \multirow[t]{2}{*}{9} \\
\hline 0 & 0 & -- & ريف & & \\
\hline $14.83 \%$ & 30 & ITr & حضر & \multirow[t]{2}{*}{ السادات } & \multirow[t]{2}{*}{1.} \\
\hline $4.95 \%$ & 13 & $1 \cdot v$ & ريف & & \\
\hline$\% \vee 0, \leq 4$ & & $\wedge 9 \vee$ & حضر & \multirow{2}{*}{\multicolumn{2}{|c|}{ اجمالي المحافظة }} \\
\hline$\% \wedge r, O r$ & & rit. & ريف & & \\
\hline
\end{tabular}

يتضح من جدول ( () التوزيع النسبي لمجتمع وعينة الدراسة من معلمات مرحلة الطفولة المبكرة بالمدارس الحكومية موزعة على الإدارات المختلفة بمحافظة المنوفية وقد بلغت نسبة عينة البحث (ريف: Y Y,Or

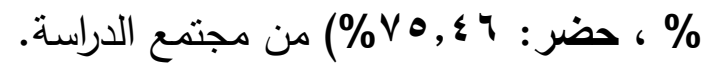




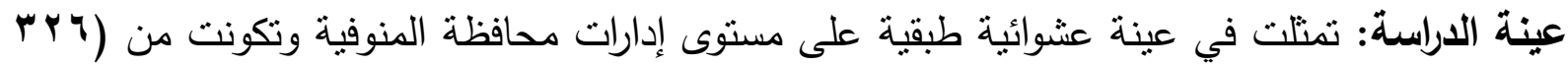

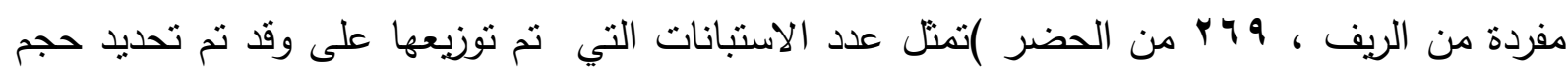

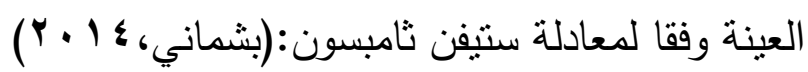

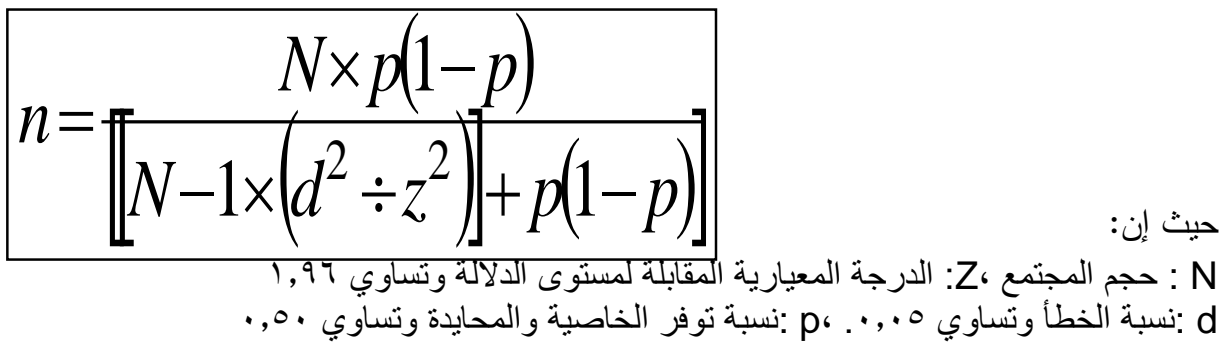
واستقرت عينة الدراسة على الأعداد التفصيلية بعد توزيع والاستبانات وتنلمها بعد ذلك وفقاً للبيانات

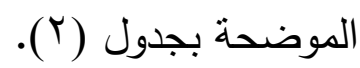

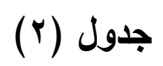

\begin{tabular}{|c|c|c|c|c|c|c|c|}
\hline الاستجابة & الصحيحة & المستبعد & الفاقد & الموزعة & الكلتيح & رضف / رضر & الكلي \\
\hline$\% 82.52$ & 479 & r & & TY & r19. & ريف & \multirow{2}{*}{$r . \Delta V$} \\
\hline$\% 75.46$ & $r \cdot r$ & 19 & $\leqslant V$ & Y7q & ^१४ & حضر & \\
\hline
\end{tabular}

أعداد الاستبانات الموزعة والمستلمةلعينة الدراسة

أدوات الاراسة الميدانية:

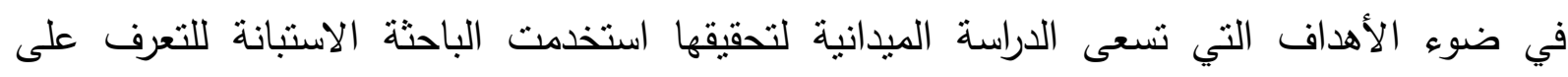
سبلنطوير الكفايات الأدائية للمعلمات بمرحلة الطفولة المبكرة في ضوء منطلبات العصر الرقمي، وقد الردانه تضنت الاستبانة محاورثلاثة رئيسة كالتالي:

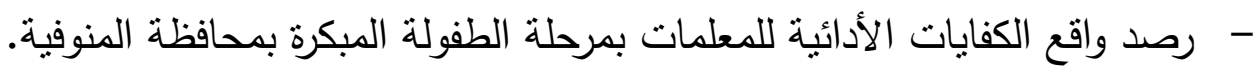
- تحديد المشكلات التي تحد من تطويرالكفايات الأدائية للمعلمات بمرحلة الطفولة المبكرة. - - التوصل لآليات نطويرالكفايات الأدائية للمعلمات بمرحلة الطفولة المبكرة بمحافظة المنوفية.

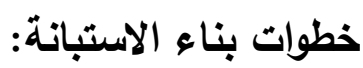
اتبعت الباحثة عدة الخطوات في بناء استبانة البحث: تحليل البيانات والمعلومات التي تم الحصول عليها

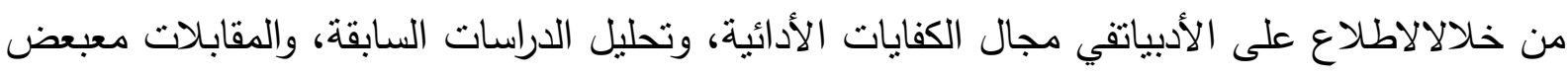

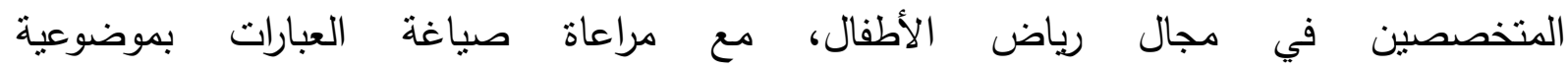
ووضوحالمعنيوبساطةاللغةتحى تحقق الهذفالذي وضعت من أجله، ووضعها في تتابع منطقي لمساعدة

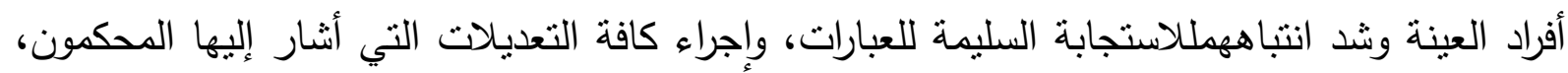

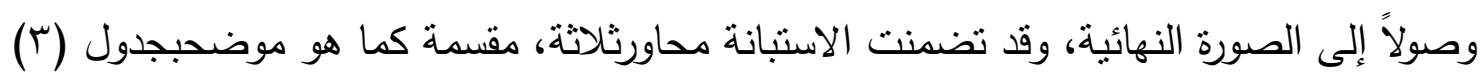




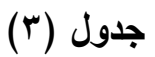

يوضح توزيع محاور الاستبانة وعدد عبارات كل محور

\begin{tabular}{|c|c|c|}
\hline 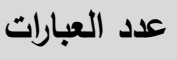 & 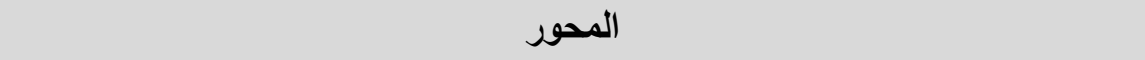 & p \\
\hline$\varepsilon r$ & واقع ممارسة الكفايات الأدائية للمعلمات بمرحلة الطفولة المبكرة & 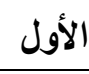 \\
\hline 10 & فيضوء متطلبات العصر الرقي تعد من تطوير الكفايات الأدائية للمعلمات بمرحلة الطقولة المبكرة & 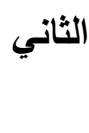 \\
\hline 19 & آليات تطوير الكفايات الأدائية للمعلمات بمرحلة الطفولة المبكرة فيضوء متطلبات & 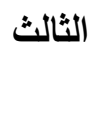 \\
\hline$\vee{ }^{4}$ & الإجمالي & \\
\hline
\end{tabular}

صدق الإستبانة:قامت الباحثة بالتأكد من صدق الإستبانة بعدة طرق: 1 - صدق المحكمين:عرضت الباحثة الإستبانة على مجموعة من المحكمين المتخصصين في ( مجال

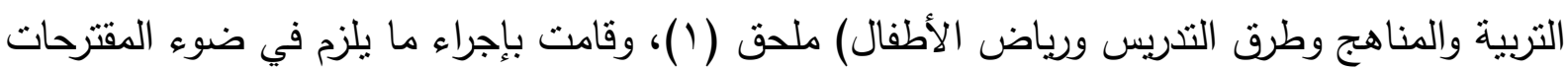
المقدمة، وبذلك خرجت الإستبانة في صورتها النهائية، ملحق (2).

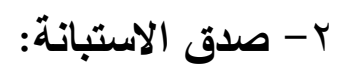
أولا: الاتساق الاخلي: يقصد بصدق الاتساق الداخلي مدى اتساق كل عبارة مع المحور الذي تتنمي إليه، وقامت الباحثة بحساب الاتساق الداخلي للإسنتبانة من خلال حساب معاملات الارتباط بين درجة كل عبارة الإق والدرجة الكلية للمحور الذي تتنمي إليه.

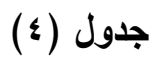

يوضح معاملات ارتباط درجة كل عبارة والدرجة الكلية للمحور الأول الأي تتنمي إليه

\begin{tabular}{|c|c|c|c|c|}
\hline الاحصائية & مستوي & الارتباط معامل & 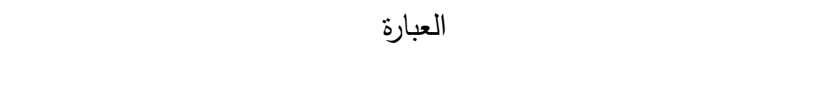 & s \\
\hline \multicolumn{5}{|c|}{ أولاً: كفايات التخطيط } \\
\hline 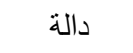 & .000 & 0.874 & تحديد الوسائل التعليمية المناسبة لتحقيق أهداف الموضوع & 1 \\
\hline 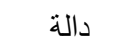 & .000 & 0.868 & تحديد الأنشطة المرتبطة بالموضوع & r \\
\hline دالة & .000 & 0.789 & تحدد نواتج التعلم & r \\
\hline دالة & .000 & 0.887 & تحديد التمهيد المناسب & $\varepsilon$ \\
\hline دالة & .000 & 0.922 & تحديد الاستراتيجيات الترريسية & $\circ$ \\
\hline دالة & .000 & 0.847 & تحديد المحتوي التعليمي & 1 \\
\hline \multicolumn{5}{|c|}{ ثانياً: كفايات التنفيذ } \\
\hline دالة & .000 & 0.592 & التمهيد للموضوع باستخدام المدخل المناسب للأهداف وطريقة تدريسه & v \\
\hline دالة & .000 & 0.555 & استثارة اهتمامات الأطفال للموضوع بأساليب تربوية مشوقة & $\wedge$ \\
\hline دالة & .003 & 0.297 & استخدام طرق التدريس المناسبة لتحقيق أهداف الموضوع & 9 \\
\hline دالة & .000 & 0.601 & يستخدم الوسائل التعليمة المناسبة للموضوع في الوقت المناسب أثناء تدريسه & 1. \\
\hline دالة & .000 & 0.483 & مشاركة الأطفال في المناقثة والحوار & 11 \\
\hline دالة & .000 & 0.567 & الاستخدام الفعال لأساليب متتوعة لإثارة الدافعية لدي الأطفال & ir \\
\hline
\end{tabular}




\begin{tabular}{|c|c|c|c|c|}
\hline دالة & .000 & 0.786 & تهيئة الجو النفسي الذي بسمح للطفل بالتعبير عن نفسه ودوافعه وحاجاته & ir \\
\hline دالة & .000 & 0.824 & التعامل مع القضايا الصفية الدفاجئة & $1 \varepsilon$ \\
\hline دالة & .000 & 0.707 & غرس اتجاهات ايجابية في نفوس الأطفال نحو الانضباط الذاتي & 10 \\
\hline دالة & .000 & 0.789 & السماح للأطفال بالحركة داخل الفصل دون الاخلال بالنظام & 17 \\
\hline دالة & .000 & 0.757 & الروضة مساعدة الاطفال على تكوين علاقات اجتماعية مع أقرانهم الكبار في مجتمع & iv \\
\hline دالة & .000 & 0.659 & مساعدة الأطفال على حل مشكلاتهم والتصرف السليم في المواقف المختلفة & 11 \\
\hline دالة & .000 & 0.589 & الروضة الاعدة الطفال على التعرف على حقوقهم وواجباتهم ومسئولياتهم في & 19 \\
\hline دالة & .000 & 0.552 & تعود الأطفال على نظافة الفصل & r. \\
\hline دالة & .000 & 0.645 & مساعدة الأطفال على الانضباط الذاتي & r \\
\hline دالة & .000 & 0.462 & مراعاة المساواة في التعامل مع الأطفال & rr \\
\hline دالة & .000 & 0.685 & مراعاة المرونة في التعامل مع الأطفال & $r$ \\
\hline دالة & .000 & 0.682 & توزيع المسئوليات على الأطفال بما بتماثني وقدراتهم ورغباتهم & $r \varepsilon$ \\
\hline دالة & .000 & 0.673 & تقبل آراء الأطفال & ro \\
\hline دالة & .000 & 0.641 & تقبل أخطاء الأطفال بصبر & ry \\
\hline دالة & .033 & 0.335 & إضفاء جواً من المرح والبهجة في الفصل & tr \\
\hline دالة & .000 & 0.599 & مساعدة الاطفال على آداب تتاول الطعام & rA \\
\hline دالة & .000 & 0.563 & 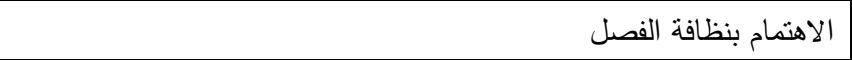 & rq \\
\hline دالة & .002 & 0.324 & تشجيع الأطفال على العمل بروح الفريق & r. \\
\hline دالة & .000 & 0.349 & تشجيع الأطفال على إبداء آرائهم & 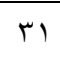 \\
\hline دالة & .000 & 0.698 & تشجيع الأطفال على تقبل آراء الآخرين & rt \\
\hline \multicolumn{5}{|c|}{ ثالثاً: كفايات التقويم } \\
\hline دالة & .000 & 0.703 & تقوم نواتج التعلم المعرفية & r \\
\hline دالة & .000 & 0.702 & تقوم نواتج التعلم الوجدانية & $r \varepsilon$ \\
\hline دالة & .000 & 0.548 & تقوم نواتج النعلم المهارية & ro \\
\hline دالة & .002 & 0.318 & تنتن استخدام اساليب التقويم المختلفة & r \\
\hline دالة & .000 & 0.658 & تتقف بناء الاختبارات التي تقيس مستويات الأهداف المعرفية المختلفة & rV \\
\hline دالة & .000 & 0.725 & تنقف صياغة الأسئلة بمستويات مختلفة تراعي الفروق الفردية & rᄉ \\
\hline دالة & .000 & 0.703 & صياغة اسئلة تنمي مهارات التفكير المختلفة لدي الأطفال & rq \\
\hline دالة & .000 & 0.752 & استثارة افكار الأطفال & $\varepsilon \cdot$ \\
\hline دالة & .000 & 0.516 & تقديم انشطة تشجع على التفكير & $\varepsilon 1$ \\
\hline دالة & .001 & 0.340 & تصميم مواقف تعليمية تتمي مهارات التفكير لدي الأطفال & $\varepsilon r$ \\
\hline
\end{tabular}

يبين جدول (ع) معامات الارنباط بين درجة كل عبارة والدرجة الكلية للمحور الأول الذي تنتمي إليه والتي تراوحت بين (0.922 - 0.297) وجميعها دالة احصائيا عند مستوي معنوية ( ( +., •) وبذلك تعتبر عبارات الاستبانة صادقة. 


\section{جدول (0)}

يوضح معاملات ارتباط درجة كل عبارة والدرجة الكلية للمحور الثاني الذي تنتمي إليه

\begin{tabular}{|c|c|c|c|c|}
\hline الاحصائية & مستوي & الارتباط & 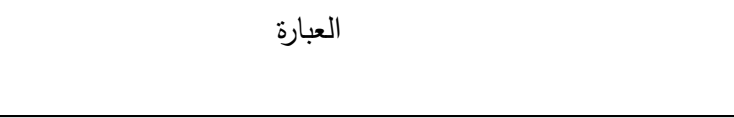 & s \\
\hline \multicolumn{5}{|c|}{ مايخص التجهيزات } \\
\hline دالة & .000 & 0.671 & عدم توفر برمجيات تعليمية أو تدريبية في مجال التخصص & 1 \\
\hline دالة & .000 & 0.792 & نقص التجهيزات اللازمة لتوظيف المعلوماتية في التعليم والتدريب & r \\
\hline دالة & .000 & 0.820 & عدمتوفرخدمة|لانترنتبرياضالأطفال & $r$ \\
\hline دالة & .000 & 0.862 & ضعف الامكانات المادية & $\varepsilon$ \\
\hline دالة & .000 & 0.840 & ضعف التدريب على اساسيات استخدام الحاسب الآلي & $\circ$ \\
\hline دالة & .000 & 0.866 & ندرة استخدام تطبيقات الحاسب الآلي في التعليم & 1 \\
\hline دالة & .000 & 0.806 & تدني معرفة انسب تطبيقات الحاسب الآلي لأطفال مرطلة الروضة & 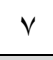 \\
\hline \multicolumn{5}{|c|}{ 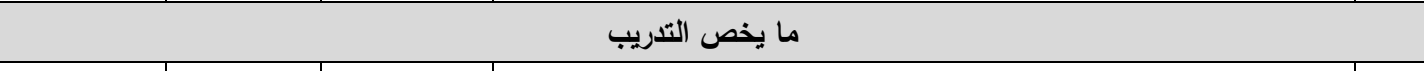 } \\
\hline دالة & .000 & 0.608 & قلة معرفة كيفية الوصول إلى المعلومات المنشورة آلياً & $\wedge$ \\
\hline دالة & .000 & 0.694 & نقص التنريب على لغات برمجة معينة & 9 \\
\hline دالة & .000 & 0.765 & نقص التنريب على توظيف تطييقات الحاسب الآلي في التدريس & 1. \\
\hline دالة & .000 & 0.652 & نقص التدريب على تصميم وتطوير مقررات دراسية & 11 \\
\hline دالة & .000 & 0.715 & نقص التدريب في مجال تكنولوجيا المعلومات & ir \\
\hline دالة & .000 & 0.730 & عدم التعرف على البرمجيات الجديدة & 14 \\
\hline دالة & .000 & 0.738 & ندرة الدورات الفنية التخصصية لمعلمات رياض الأطفال & $1 \leq$ \\
\hline دالة & .000 & 0.664 & ضعف التنريب في مجال تكنولوجيا المعلومات & 10 \\
\hline
\end{tabular}

يبين جدول (0) معاملات الارتباط بين درجة كل عبارة والدرجة الكلية للمحور الثاني الذي تنتمي إليه

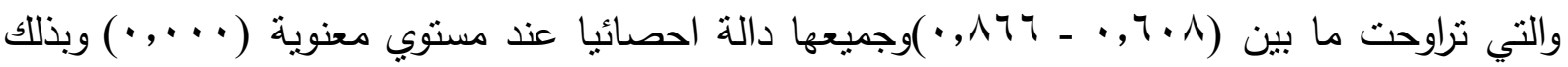
تعتبر عبارات الاستبانة صادقة لما وضعت له

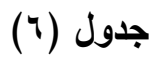

يوضح معاملات ارتباط درجة كل عبارة والارجة الكلية للمحور الثالث الذي تنتمي إليه

\begin{tabular}{|c|c|c|c|c|}
\hline الاحصائية & مستوي الدلالة & الارتباط معامل & 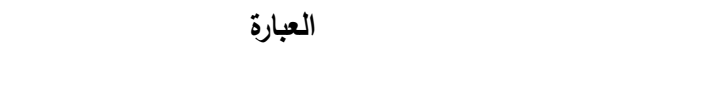 & s \\
\hline \multicolumn{5}{|c|}{ مهارات التفكير العليا والتفكير الناقد } \\
\hline دالة & .000 & 0.580 & القدرة على توظيف المعلومات في حل المشكلات & 1 \\
\hline دالة & .030 & 0.343 & القدرة على اختيار المعلومات النافعة & 2 \\
\hline دالة & .000 & 0.588 & القدرة على نقد المعلومات وتقسيرها & 3 \\
\hline دالة & .000 & 0.656 & القدرة على استخدام المعلومات في انتاج أفكار جديدة & 4 \\
\hline دالة & .000 & 0.591 & امتلاكك مهارات التفكير العلمي والابتكاري & 5 \\
\hline \multicolumn{5}{|c|}{ 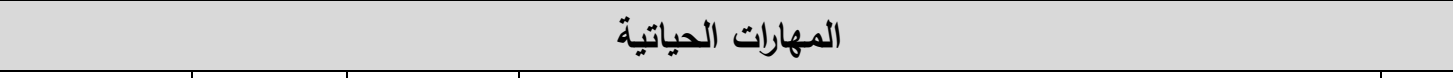 } \\
\hline دالة & .000 & 0.540 & امتلاك مهارات التعلم الذاتي & 6 \\
\hline
\end{tabular}




\begin{tabular}{|c|c|c|c|c|}
\hline دالة & .000 & 0.511 & التعامل باييجابية مع المتغيرات والمستجدات العالمية & 7 \\
\hline دالة & .000 & 0.583 & القدرة مراعاة خصائص الأطفال والفروق الفردية بينهم & 8 \\
\hline دالة & .000 & 0.537 & القدرة على التعامل مع الأزمات والمواقف الضاغطة & 9 \\
\hline دالة & .000 & 0.542 & التمكن من مهارات إدارة الوقت بفاعلية & 10 \\
\hline دالة & .005 & 0.470 & القدرة على مواجهة التحديات التي يفرضها العصر الرقمي & 11 \\
\hline \multicolumn{5}{|c|}{ توظيف التكنولوجيا } \\
\hline دالة & .000 & 0.503 & القدرة على جمع المعلومات وتصنيفها & 12 \\
\hline دالة & .000 & 0.589 & التمكن من مفاهيم ومصطلحات تكنولوجيا المعلومات & 13 \\
\hline دالة & .000 & 0.544 & القدرة على تصميم قاعدة بيانات & 14 \\
\hline دالة & .000 & 0.581 & القدرة على تصميم البرمجيات التعليمية & 15 \\
\hline دالة & .000 & 0.694 & التمكن من مهارات الاتصال الاككتروني & 16 \\
\hline دالة & .000 & 0.448 & القدرة على الاتصال بالمكتبات ومصادر المعلومات المختلفة & 17 \\
\hline دالة & .006 & 0.293 & امتلاك مهارة البحث عن المعلومات في الإنترنت & 18 \\
\hline دالة & .000 & 0.467 & التمكن من مهارة تتغيل الملفات الصوتية والفيديو باستخدام & 19 \\
\hline
\end{tabular}

يبين جدول (T) معامالات الارنباط بين درجة كل عبارة والدرجة الكلية للمحور الثالث الذي تتنمي إليه والتي تراوحت ما بين (ب9 ( , - - 0.694)وجميعها دالة إحصائية عند مستوى معنوية (000.)وبذلك تعتبر عبارات الاستبانة صادقة لما وضعت. ثانيا: نتائج الصدق البنائي

\section{جدول (v)}

يوضح معاملات الارتباط بين الدرجة الكلية لكل محور والدرجة الكلية للاستبانة.

\begin{tabular}{|c|c|c|c|}
\hline 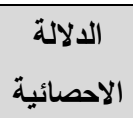 & الدلالة & معامل & محاور الاستبانة \\
\hline دالة & .000 & 0.942 & المبكرة بمحافظة الأول: واقع ممارسة الكفايات الأدائيةللمعلمات بمرحلة الطفولة \\
\hline دالة & .000 & 0.904 & المرحلة الطفولة الثاني: المشكلات التي تحدة منتطوير الكفايات الأدائية للمعلمات \\
\hline دالة & .000 & 0.762 & الأدائية للمعلمر الثالث: متطلبات العصر الرقمي التي تسهم في تطوير الكفايات \\
\hline
\end{tabular}

يبين جدول (V)معاملات الإرتباط بين الدرجة الكلية لكل محور والدرجة الكلية للاستبانة حيث نراوحت ما

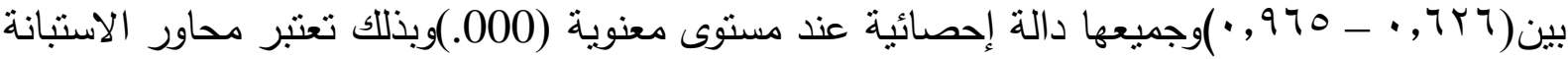


ثالثا: نتائج الصدق الذاتي:نتائج الصدق الذاتي موضحة في جدول (^)وهي مرتفعة مما يدل على الصلة الوثيقة بين الصدق الذاتي والثبات. رابعا: نتائج ثبات الاستبانة ومحاورها: وقد تحققت الباحثة من ثبات الإستبانة بطريقة معامل ألفا كرونباخ

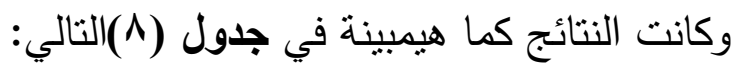
جدول (^)؛ نتائج ثبات الاستبانة ونتائج الصدق الأتي

\begin{tabular}{|c|c|c|}
\hline 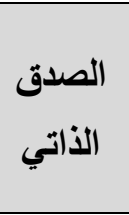 & كرونباخ & محاور الاستبانة \\
\hline .959 & .919 & المحور الأول: واقع ممارسة الكفايات الأدائية للمطلمات بمرحلة الطفولة المبكرة بمحافظة \\
\hline .961 & .923 & المحور الثاني: المشكلات التي تحد من تطوير الكفايات الأدائية للمعلمات بمرحلة الطفولة المبكرة \\
\hline .865 & .748 & المحور الثالث: متطلبات العصر الرقمي التي تسهم في تطوير الكفايات الأدائية للمعلمات بمرحلة \\
\hline \&, & - & الاستبانة ككل \\
\hline
\end{tabular}

يتضح من جدول (^) أن معاملات الثبات لمحاور الاستبانة نزاوحت بين (748. -919.وللاستبانة ككل

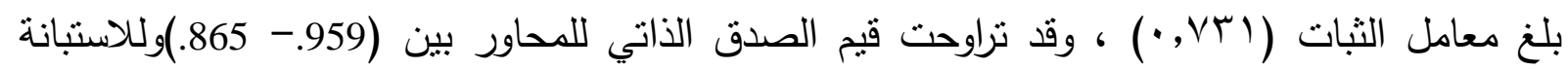

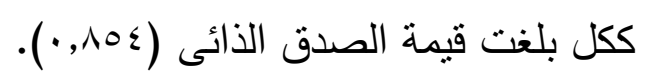
تحليل نتائج الدراسة الميدانية: نم تحليل آراء عينة من معلمات مرحلة الطفولة المبكرة بمحافظة المنوفية

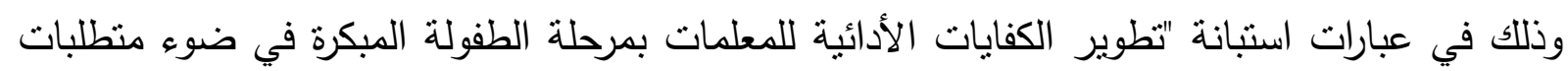

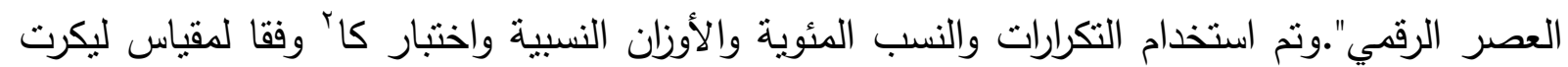
الخماسي التالي: - n

جدول (9): مقياس ليكرت الخماسي

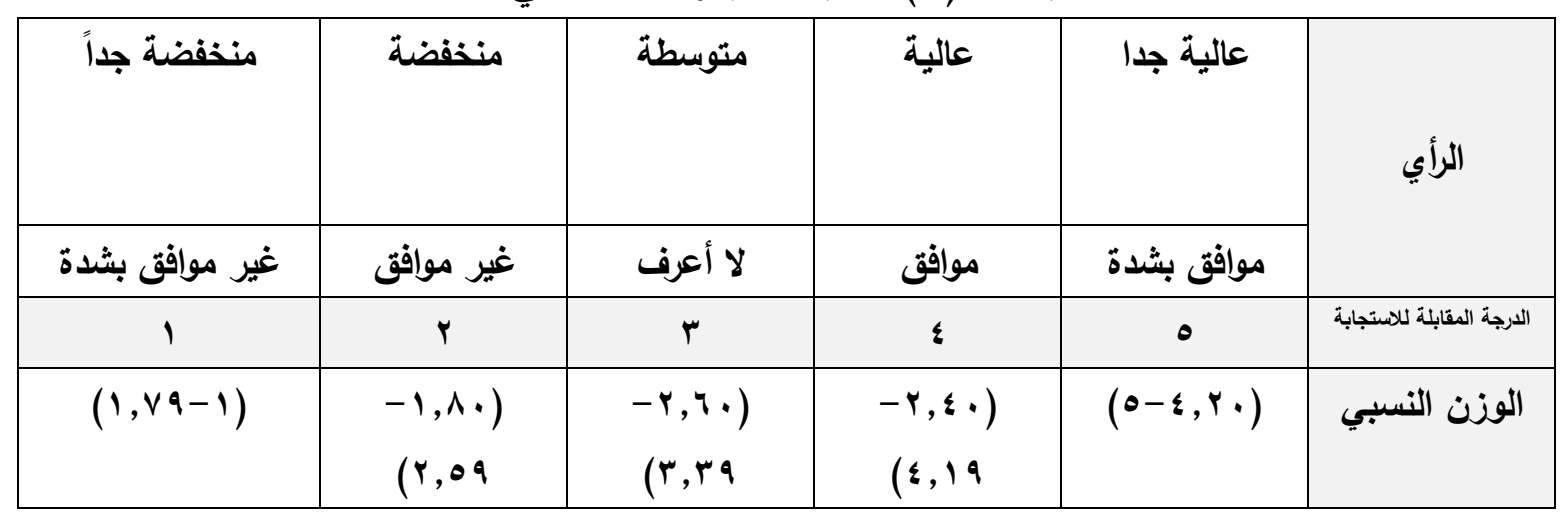




\section{جدول (1.)}

نتائج اختبار "كاء" لدلالة الفروق ب ين آراء أفراد عينة الدراسة في عبارات المحور الأول: واقع ممارسة الكفايات الأدائية لمعلمات مرحلة الطفولة المبكرة (كفايات التخطيط)

\begin{tabular}{|c|c|c|c|c|c|c|c|c|c|c|c|c|}
\hline \multirow{3}{*}{ الترتيب } & \multirow{3}{*}{ 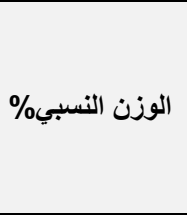 } & \multirow{3}{*}{ 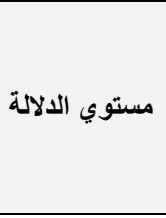 } & \multirow{3}{*}{ Sil } & منذفا & 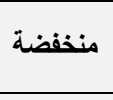 & 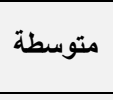 & عالية & عالية & \multirow{3}{*}{ الاتمعراف } & \multirow{3}{*}{ المرجح } & \multirow{3}{*}{ 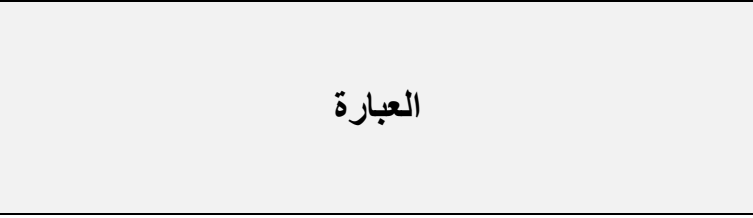 } & \multirow{3}{*}{ r } \\
\hline & & & & \multicolumn{5}{|c|}{ نسبة التكرار على المقياس } & & & & \\
\hline & & & & $\%$ & $\%$ & $\%$ & $\%$ & $\%$ & & & & \\
\hline 3 & 80.55 & .000 & 10.757 & 03.60 & 09.11 & 06.36 & 42.80 & 38.14 & 1.065 & 4.03 & تحديد الوسائل التعلمية المناسبة لتحقيق أهداف الموضوع & 1 \\
\hline 4 & 79.45 & .000 & 9.510 & 00.21 & 14.83 & 13.77 & 29.87 & 41.31 & 1.079 & 3.97 & تحديد الأنشطة المرتبطة بالموضوع & r \\
\hline 2 & 81.19 & .000 & 11.697 & 01.06 & 12.29 & 07.84 & 37.29 & 41.53 & 1.039 & 4.16 & تحديد نو اتج التعلم & $r$ \\
\hline 6 & 71.27 & .000 & $\varepsilon .448$ & 05.30 & 05.51 & 28.39 & 49.15 & 11.65 & .953 & 3.56 & تحديد التمهيد المناسب & $\varepsilon$ \\
\hline 1 & 81.74 & .000 & 13.986 & 01.06 & 04.45 & 17.80 & 38.14 & 38.56 & .912 & 4.09 & تحديد الاستر اتيجيات التدريسية & 0 \\
\hline 5 & 79.19 & .000 & 12.903 & 01.27 & 01.48 & 19.92 & 54.66 & 22.67 & .774 & 3.96 & تحديد المحتوي التعليمي & 7 \\
\hline
\end{tabular}


يوضح جدول (· ()نتائج اختبار كا' الدلالة الفروق بين آراء أفراد عينة الدراسة من معلمات مرحلة الطفولة المبكرة بالمدارس الحكومية بمحافظة المنوفية في عبارات المحور الأول واقع ممارسة الكفايات الأدائية للمعلمات بمرحلة الطفولة المبكرة (كفايات التخطيط) حيث ثراوحت قيم

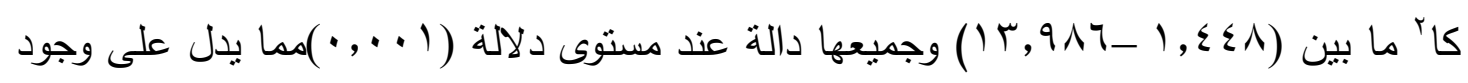
فروق دالة إحصائية بين آراء أفراد عينة الدراسة لصالح الاستجابة عالية لجميع العبارات. تفسير نتائج المحور الأول:إتجهت آراء أفراد عينة الدراسة نحو استجابة عالية، وذلك بوزن نسبى (\% 9 \%)،فالغرض من توفر كفايات التخطيط هو توجيه العمل بحيث لا بيترك شئ للعشوائية أو الصدفة أو الارتجال، وذلك من خلال وضع المعلمة خطة للنشاط المقدم للطفل واتخاذ إجراءات مسبقة من شأنها بلوغ الأهداف التربوية التي تسعى معلمة الطفولة المبكرة إلى تحقيقها، ويري البحث الحالي أن التخطيط هو تتظيم عملية تحقيق الأهداف في ضوء الإمكانات والظروف المتاحة وتتمل وضع خطة لمعرفة ددى تحقيق الأهداف، واتقق بذلك البحث الحالي

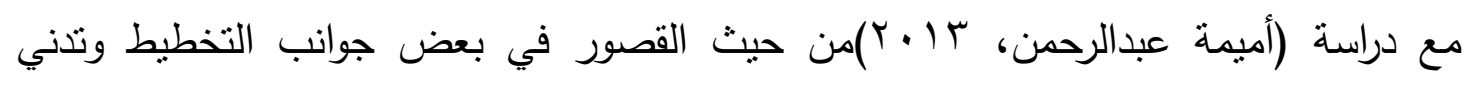
تحقيق بعض جوانب وأدوات التقويم، بسبب كثرة الأعباء الوظيفية والتكليفات على معلمات مرحلة الطفولة المبكرة؛ وقد جاء الترتيب الجديد لعبارات المحور الأول واقع ممارسة الكفايات الأدائية للمعلمات بمرحلة الطفولة المبكرة (كفايات التخطيط) من حيث الأهمية، كما هو موضح بجدول

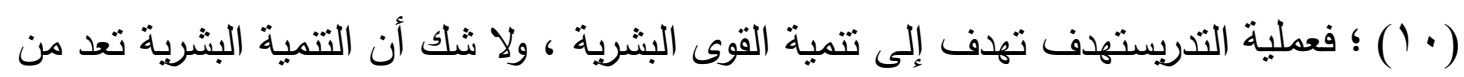
أهم أنواع التتمية، إذ تتوقف عليها التتمية فى المجالات الأخرى، وكما أن الدور الرئيسى لإعداد الكوادر البشرية فى توافر تلك الكوادر، ولذلك تتضح الأهمية الكبرى لعملية التذريس فى بناء الاقتصاد القومى، ومن ثم فإن التدريس شأنه شأن كل الأعمال الهامة لابد أن يكون مخططا تخطيطا دقيقا حتى مخرجات التعليم الأهداف المرغوبة، ولا أحد بنكر الدور الهام الذى يقوم به المعلم فى عملية التدريس ، حيث تقع على عاتقه مسئولية التخطبط لعملية التدريس، وتتفيذها وتقويمها، وإن لم يكن المعلم ملما بمهارات التدريس، متمكنا منها، فسوف تخضع عملية التدريس على عله للارتجال والعفوية التى تفتقد إلى التخطيط المحكم، والتنظيم الذى يهدف إلى رسم الأسلوب

$$
\text { وطريقة العمل، مما يقلل من فرص تحقيق الأهداف المرغوبة. }
$$

وتعد مهارة التخطيط للتدريس من المهارات الأساسية التى تمثل عملية عقلية بالتتظيم ، وتهدف إلى تحديد خطوات العمل الذى يؤدى إلى بلوغ الأهداف المرجوة التى تتمنل فى إكساب المتعلمين مجموعة من الخبرات التربوية الهادفة . 
جدول (11): يوضح نتائج اختبار (كا؟) لدلالة الفروق بين آراء أفراد عينة الدراسة في عبارات المحور الأول: واقع ممارسة الكفايات الأدائية لمعلمات رياض الأطفال (كفايات التنفيذ)

\begin{tabular}{|c|c|c|c|c|c|c|c|c|c|c|c|c|}
\hline \multirow{3}{*}{ الترتيب } & \multirow{3}{*}{ النسبي\%\% } & \multirow{3}{*}{ مستوي } & \multirow{3}{*}{ كاי } & منغفضة جدا & 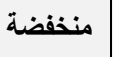 & 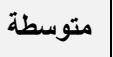 & عالية & 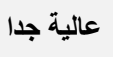 & \multirow{3}{*}{ المعياري } & \multirow{3}{*}{ المرجح } & \multirow{3}{*}{ 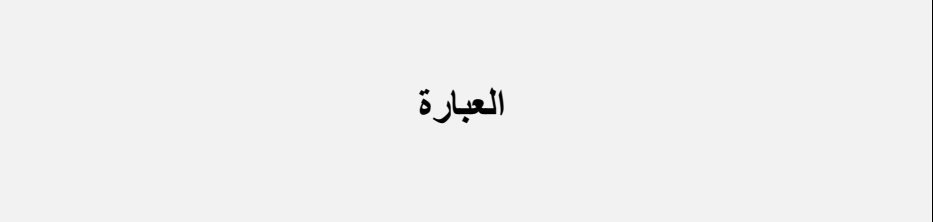 } & \multirow{3}{*}{ r } \\
\hline & & & & \multicolumn{5}{|c|}{ 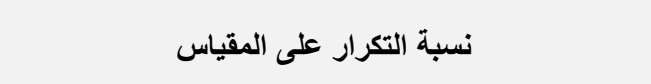 } & & & & \\
\hline & & & & $\%$ & $\%$ & $\%$ & $\%$ & $\%$ & & & & \\
\hline 6 & 82.42 & .000 & 12.389 & 01.69 & 07.63 & 20.76 & 16.74 & 53.18 & 1.089 & 4.12 & التمهيد للموضوع باستخدام المدخل المناسب للأهداف وطريقة تدريسه & 1 \\
\hline 17 & 75.34 & .000 & 5.171 & 03.18 & 08.26 & 33.26 & 19.28 & 36.02 & 1.121 & 3.77 & استشارة اهتمامات الأطفال للموضوع بأساليب تربوية مشوقة & r \\
\hline 4 & 83.09 & .000 & 13.977 & 00.21 & 05.93 & 26.06 & 13.77 & 54.03 & 1.018 & 4.15 & استخدام طرق التدريس المناسبة لتحقيق أهداف الموضوع & $\mu$ \\
\hline 14 & 77.33 & .000 & 7.028 & 02.12 & 11.44 & 24.58 & 21.40 & 40.47 & 1.133 & 3.87 & بستخدم الوسائل التعليمة المناسبة للموضوع في الوقت المناسب أثثاء تدريسه & $\varepsilon$ \\
\hline 7 & 81.48 & .000 & 12.200 & 01.48 & 11.23 & 06.14 & 40.68 & 40.47 & 1.022 & 4.07 & مشاركة الأطفال في المناقثة والحوار & 0 \\
\hline 1 & 84.79 & .000 & 15.881 & 00.64 & 09.96 & 08.26 & 27.12 & 54.03 & 1.012 & 4.24 & الاستخدام الفعال لأساليب متتوعة لإثارة الدافعية لدي الأطفال & 7 \\
\hline 5 & 82.88 & .000 & 13.418 & 00.85 & 10.17 & 12.50 & 26.69 & 49.79 & 1.043 & 4.14 & تهيئة الجو النفسي الذي يسمح للطفل بالتعبير عن نفسه ودوافعه وحاجاته & V \\
\hline 10 & 80.30 & .000 & 10.124 & 04.66 & 07.20 & 10.59 & 37.08 & 40.47 & 1.105 & 4.01 & التعامل مع القضايا الصفية المفاجئة & $\Lambda$ \\
\hline 3 & 83.31 & .000 & 15.107 & 01.27 & 06.78 & 10.81 & 36.44 & 44.70 & .957 & 4.17 & غرس اتجاهات ايجابية في نفوس الأطفال نحو الانضباط الذاتي & 9 \\
\hline 11 & 79.03 & .000 & 9.498 & 03.60 & 06.36 & 15.04 & 41.31 & 33.69 & 1.032 & 3.95 & السماح للأطفال بالحركة داخل الفصل دون الاخلال بالنظام & 1. \\
\hline 12 & 78.31 & .000 & 8.950 & 04.24 & 04.24 & 17.16 & 44.49 & 29.87 & 1.008 & 3.92 & مساعدة الاطفال على تكوين علاقات اجتماعية مع أقرانهم الكبار في مجتمع الروضة & 11 \\
\hline 9 & 80.64 & .000 & 12.056 & 00.85 & 04.87 & 24.58 & 29.66 & 40.04 & .958 & 4.03 & مساعدة الأطفال على حل مشكلاتهم والتصرف السليم في المواقف المختلفة & IT \\
\hline 18 & 74.62 & .000 & 5.140 & 02.97 & 04.45 & 33.47 & 34.75 & 24.36 & .976 & 3.73 & مساعدة الأطفال على التعرف على حقوقهم وواجباتهم ومسئولياتهم في الروضة & $\pi$ \\
\hline 24 & 63.39 & .000 & 8.816 & 06.14 & 05.51 & 55.72 & 30.51 & 02.12 & .814 & 3.17 & تعود الأطفال على نظافة الفصل & $1 \leqslant$ \\
\hline 21 & 68.90 & .000 & £.208 & 06.14 & 05.08 & 40.04 & 35.59 & 13.14 & .991 & 3.44 & مساعدة الأطفال على الانضباط الذاتي & 10 \\
\hline 16 & 75.55 & .000 & 7.637 & 01.69 & 05.72 & 17.37 & 63.56 & 11.65 & .790 & 3.78 & مراعاة المساواة في التعامل مع الأطفال & 17 \\
\hline 13 & 77.63 & .000 & 8.760 & 01.69 & 08.69 & 15.04 & 48.94 & 25.64 & .946 & 3.88 & مراعاة المرونة في التعامل مع الأطفال & iv \\
\hline 20 & 72.71 & .002 & 3.107 & 05.30 & 04.87 & 23.31 & 54.03 & 12.50 & .948 & 3.64 & توزيع المسئوليات على الأطفال بما يتماشي وقدراتهم ورغباتهم & 11 \\
\hline 8 & 80.89 & .000 & 11.550 & 01.48 & 10.17 & 10.81 & 37.50 & 40.04 & 1.024 & 4.04 & تقبل آراء الأطفال & 19 \\
\hline
\end{tabular}




\begin{tabular}{|c|c|c|c|c|c|c|c|c|c|c|c|c|}
\hline 15 & 76.61 & .000 & 6.938 & 04.03 & 05.30 & 23.31 & 38.35 & 29.03 & 1.035 & 3.83 & تقبل أخطاء الأطفال بصبر & $r$. \\
\hline 2 & 84.19 & .000 & 15.176 & 01.69 & 04.24 & 20.34 & 18.86 & 54.87 & 1.016 & 4.21 & إضفاء جواً من المرح والبهجة في الفصل & rI \\
\hline 25 & 61.23 & .000 & 9.628 & 05.30 & 22.46 & 40.68 & 23.94 & 07.63 & .990 & 3.06 & مساعدة الاطفال على آداب تتاول الطعام & rr \\
\hline 26 & 59.32 & .000 & 10.530 & 05.30 & 34.75 & 29.66 & 18.64 & 11.65 & 1.101 & 2.97 & الاهتمام بنظافة الفصل & rT \\
\hline 23 & 65.30 & .000 & 4.303 & 00.85 & 35.81 & 21.61 & 19.49 & 22.25 & 1.187 & 3.26 & تشجيع الأطفال على العمل بروح الفريق & $r \varepsilon$ \\
\hline 22 & 67.42 & .010 & 2.589 & 00.85 & 27.54 & 22.25 & 32.42 & 16.95 & 1.085 & 3.37 & تشجيع الأطفال على إبداء آرائهر & ro \\
\hline 19 & 73.14 & .000 & 4.007 & 01.48 & 08.47 & 24.79 & 53.39 & 11.86 & .850 & 3.66 & تشجيع الأطفال على تقبل آراء الآخرين & rq \\
\hline
\end{tabular}


بيين جدول (11) نتائج اختبار "كا؟" لدلالة الفروق بين آراء افراد عينة البحث من المعلمات بمرحلة الطفولة المبكرة بالمدارس الحكومية بمحافظة المنوفية في عبارات المحور الأول واقع ممارسة الكفايات الأدائية للمعلمات بمرحلة الطفولة المبكرة (كفايات التتفيذ) حيث تراوحت قيم

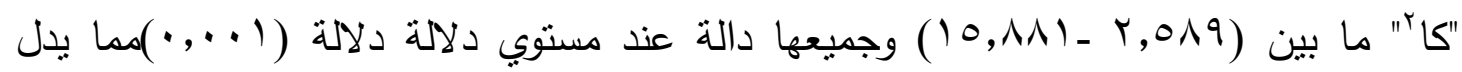
على وجود فروق دالة إحصائية بين آراء أفراد عينة الدراسة لصالح الممارسة عالية لجميع العبارات. مناقشة نتائجالمحور الأول فيما يخص (كفايات التنفيذ)": إتجهت آراء أفراد عينة الدراسة نحو الرأي "عالية" وذلك بوزن نسبى (^,ه \\%)، وقد جاء ترتيب عبارات المحور الأول واقع ممارسة الكفايات الأدائية لمعلمات رياض الأطفال، فمرحلة التنفيذ هي هي المرحلة التي يسعى المعلم فيها إلى انجاز ما يخطط له في المرحلة الأولى، وتتمل هذه المرحلة على مجموعة كبيرة ومثتوعة من المهارات التي يتعين على المعلم إجادتها لعل من أهمها مهارات عرض الدرس وما تتضمنه من مهارات فرعية كمهارة التهيئة ، ونتويع المثيرات، وغلق الدرس، وكذلك مهارات استخدام الأسئلة الصفية، تصنيفا وصياغة وتوجيها، ومن مهارات التتفيذ كذلك مهارة استثارة الدافعية، ومهارة التعزبز، وتنويع المثيرات، ومهارة استخدام المواد والأجهزة، ومهارة إدارة الفصل، ومهارة التعامل الإنساني. 
جدول (r ا ) يوضح نتائج اختبار (كا؟) لدلالة الفروق بين آراء أفراد عينة الدراسة في عبارات المحور الأول: واقع ممارسة الكفايات الأدائية للمعلمات بمرحلة الطفولة المبكرة (كفايات (التقويم)

\begin{tabular}{|c|c|c|c|c|c|c|c|c|c|c|c|c|}
\hline \multirow{3}{*}{ الترتيب } & \multirow{3}{*}{ النسبي\% } & \multirow{3}{*}{ مستوي } & \multirow{3}{*}{ Sis } & منفضضة جدا & منفضضة & 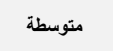 & عالية & 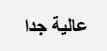 & \multirow{3}{*}{ المعياري } & \multirow{3}{*}{ المرجح } & \multirow{3}{*}{ العبارة } & \multirow{3}{*}{ r } \\
\hline & & & & \multicolumn{5}{|c|}{ نسبة التكرار على المقياس } & & & & \\
\hline & & & & $\%$ & $\%$ & $\%$ & $\%$ & $\%$ & & & & \\
\hline 7 & 74.03 & .000 & 4.888 & 05.08 & 01.06 & 25.64 & 55.08 & 13.14 & .895 & 3.70 & تقوم نواتج التعلم المعرفية & 1 \\
\hline 3 & 78.60 & .000 & 12.280 & 01.27 & 00.85 & 22.46 & 54.45 & 20.97 & .761 & 3.93 & تقوم نواتج التعلم الوجدانية & r \\
\hline 1 & 81.31 & .000 & 13.062 & 01.06 & 04.45 & 21.40 & 33.05 & 40.04 & .941 & 4.07 & تقوم نواتج التعلم المهارية & r \\
\hline 2 & 79.45 & .000 & 12.105 & 00.42 & 02.33 & 27.75 & 38.56 & 30.93 & .848 & 3.97 & تتقن استخدام اساليب التقويم المختلفة & $\varepsilon$ \\
\hline 10 & 65.81 & .000 & 5.418 & 05.08 & 01.06 & 62.29 & 22.88 & 08.69 & .841 & 3.29 & تتقف بناء الاختبارات التي تقبس مستويات الأهداف المعرفية المختلفة & 0 \\
\hline 5 & 75.17 & .000 & 7.356 & 00.85 & 00.21 & 38.35 & 43.43 & 17.16 & .763 & 3.76 & تتقف صياغة الأسئلة بمستويات مختلفة تراعي الفروق الفردية & 7 \\
\hline 9 & 69.92 & .000 & $r .103$ & 05.93 & 02.54 & 34.75 & 49.58 & 07.20 & .896 & 3.50 & صياغة اسئلة نتمي مهارات التفكير المختلفة لدي الأطفال & V \\
\hline 6 & 75.04 & .000 & 5.667 & 04.66 & 00.21 & 33.47 & 38.56 & 23.09 & .967 & 3.75 & استتارة افكار الأطفال & $\wedge$ \\
\hline 4 & 78.56 & .000 & 9.273 & 00.85 & 06.36 & 29.87 & 25.00 & 37.92 & 1.003 & 3.93 & تقديم انشطة تشجع على التقكير & 9 \\
\hline 8 & 73.47 & .000 & 5.551 & 00.21 & 01.06 & 40.25 & 48.09 & 10.38 & .680 & 3.67 & تصميم مواقف تعليمية تتمي مهارات التفكير لدي الأطفال & 1. \\
\hline
\end{tabular}


يبين جدول (r I) نتائج اختبار (كا؟) لدلالة الفروق بين آراء افراد عينة الدراسة من معلمات

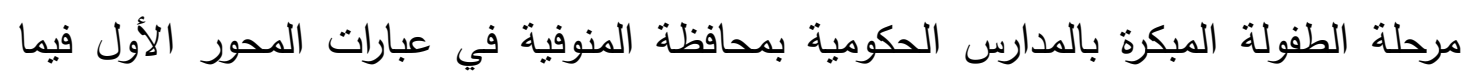

$$
\text { يخص (كفايات التقويم) }
$$

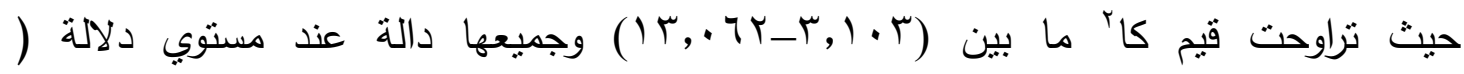

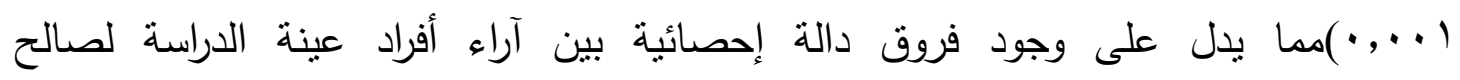

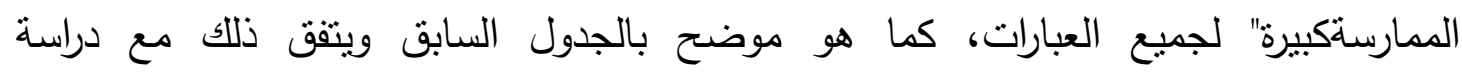

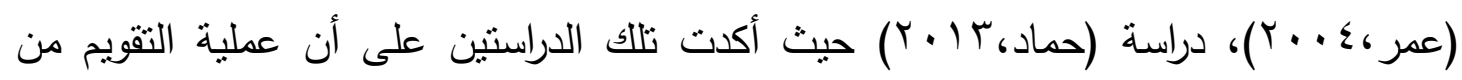

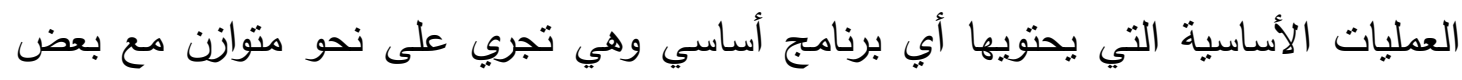

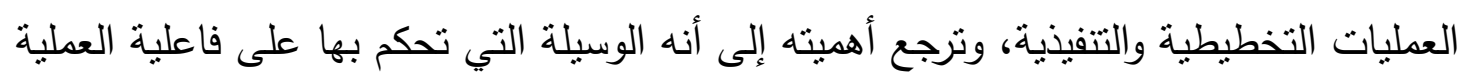
التعليمية. مناقثة نتائج المحور الأولفيما يخص (كفايات التقويم)" إتجهت آراء أفراد عينة الدراسة نحو

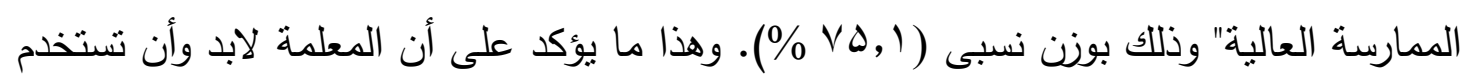

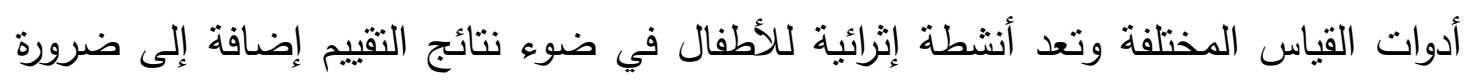

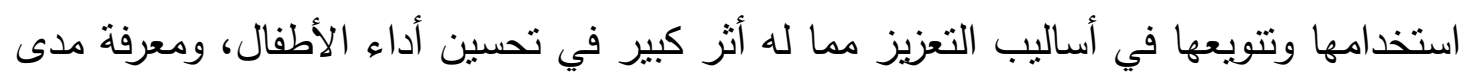

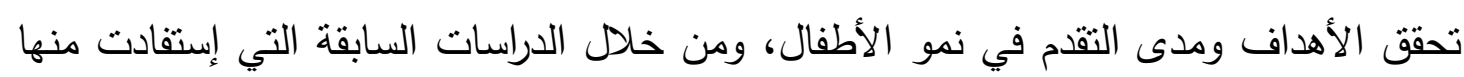

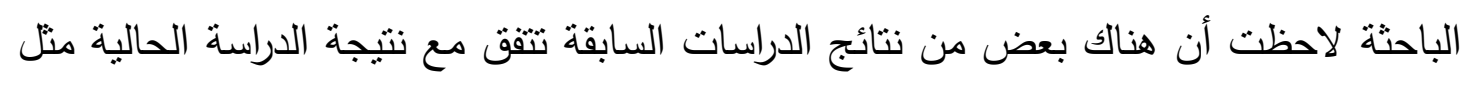

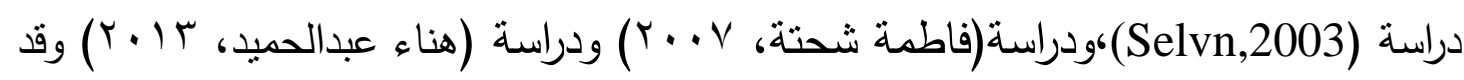

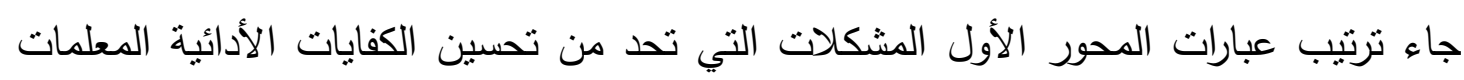

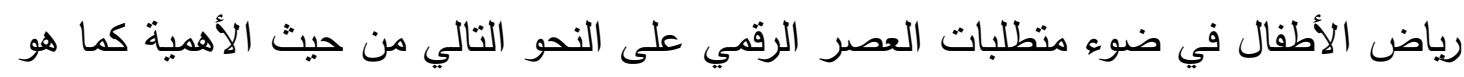

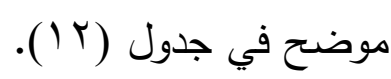
ويذلك يتم رفض فرض العدم الذي ينص على أن"لا توجد فروق ذات دلالة إحصائية بين آراء

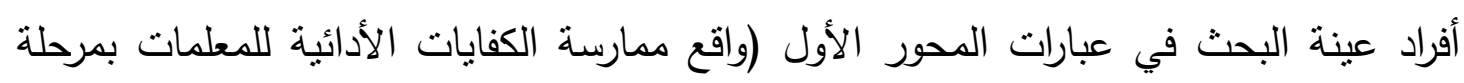

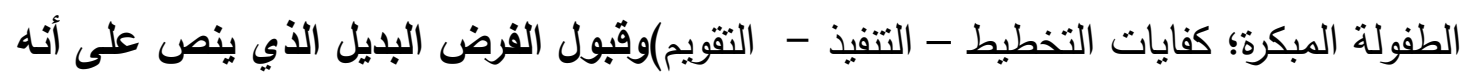

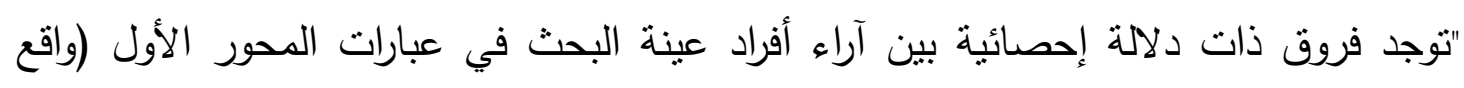

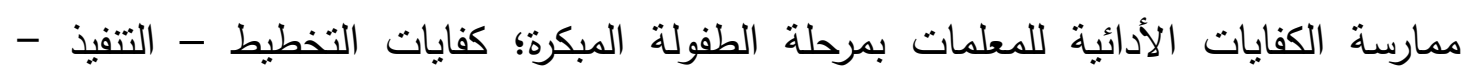


جدول (r ا - 1) يوضح نتائج اختبار (كا؟) لدلالة الفروق بين آراء أفراد عينة البحث لعبارات المحور الثاني: المشكلات التي تحد من تطوير الكفايات الأدائية للمعلمات بمرحلة الطقولة المبكرة في ضوء متطلبات العصر الرقمي

\begin{tabular}{|c|c|c|c|c|c|c|c|c|c|c|c|c|}
\hline \multirow{3}{*}{ الترتيب } & \multirow{3}{*}{ النسبي\% } & \multirow{3}{*}{ مستوية } & \multirow{3}{*}{ كاי } & موافق بثدة & غوافي & $\begin{array}{c}\text { أعرف } \\
\text { أع }\end{array}$ & 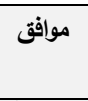 & بشدة موافق & \multirow{3}{*}{ المعياري } & \multirow{3}{*}{ المرجح } & \multirow{3}{*}{ 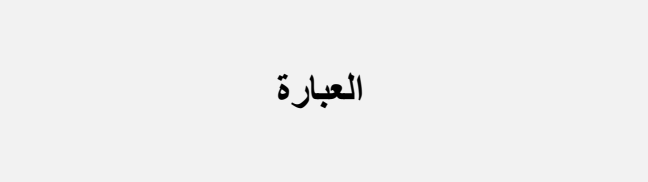 } & \multirow{3}{*}{ م } \\
\hline & & & & \multicolumn{5}{|c|}{ نسبة التكرار على المقياس } & & & & \\
\hline & & & & $\%$ & $\%$ & $\%$ & $\%$ & $\%$ & & & & \\
\hline 2 & 80.51 & .000 & 10.289 & 01.69 & 12.50 & 12.50 & 28.18 & 45.13 & 1.109 & 4.03 & نقص التجهيزات اللازمة لتوظيف المعلوماتية في التعليم والتنريب & r \\
\hline 4 & 78.86 & .000 & 10.268 & 00.85 & 04.24 & 29.03 & 31.57 & 34.32 & .937 & 3.94 & عدمتوفرخدمة|لانترنتبرياضالأطفال & r \\
\hline 1 & 81.23 & .000 & 12.247 & 00.85 & 06.57 & 21.82 & 27.12 & 43.64 & .996 & 4.06 & ندرة استخدام تطبيقات الحاسب الآلي في التعليم & 7 \\
\hline 5 & 78.64 & .000 & 9.462 & 03.60 & 03.81 & 19.70 & 41.53 & 31.36 & .992 & 3.93 & تدني معرفة انسب تطبيقات الحاسب الآلي لأطفال مرحلة الروضة & v \\
\hline
\end{tabular}

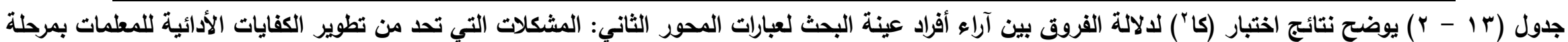
الطقولة المبكرة في ضوء متطلبات العصر الرقمي

\begin{tabular}{|c|c|c|c|c|c|c|c|c|c|c|c|c|}
\hline \multirow{3}{*}{ 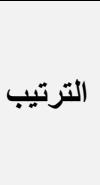 } & \multirow{3}{*}{ النسبي\% الوزن } & \multirow{3}{*}{ الدلالةي } & \multirow{3}{*}{ كاי } & موافق بثدة غير & غوافير & 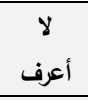 & 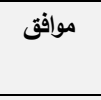 & موافق & \multirow{3}{*}{ الانحراف } & \multirow{3}{*}{ المرجح } & \multirow{3}{*}{ 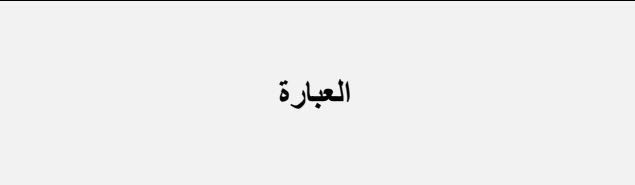 } & \multirow[t]{3}{*}{ b } \\
\hline & & & & \multicolumn{5}{|c|}{ نسبة التكرار على المقياس } & & & & \\
\hline & & & & $\%$ & $\%$ & $\%$ & $\%$ & $\%$ & & & & \\
\hline 2 & 84.15 & .000 & 14.837 & 02.12 & 07.84 & 09.11 & 29.03 & 51.91 & 1.036 & 4.21 & قلة معرفة كيفية الوصول إلى المعلومات المنشورة آلياً & $\Lambda$ \\
\hline 5 & 82.20 & .000 & 12.837 & 01.69 & 08.69 & 12.08 & 31.99 & 45.55 & 1.033 & 4.11 & نقص التدريب على لغات برمجة معينة & 9 \\
\hline 8 & 77.67 & .000 & 9.268 & 00.21 & 04.03 & 33.47 & 31.78 & 30.51 & .899 & 3.88 & نقص التذريب على توظيف تطبيقات الحاسب الآلي في التذريس & $1 \cdot$ \\
\hline 4 & 82.63 & .000 & 13.704 & 01.48 & 03.60 & 24.58 & 20.97 & 49.36 & 1.001 & 4.13 & نقص التدريب على تصميم وتطوير مقررات دراسية & 11 \\
\hline 1 & 86.06 & .000 & 16.870 & 03.81 & 02.33 & 12.92 & 21.61 & 59.32 & 1.034 & 4.30 & نقص التكريب في مجال تكنولوجيا المعلومات & ir \\
\hline 7 & 78.90 & .000 & 9.949 & 02.75 & 05.08 & 18.22 & 42.80 & 31.14 & .972 & 3.94 & علم التعرف على البرمجيات الجديدة & 14 \\
\hline 6 & 81.65 & .000 & 11.913 & 04.24 & 03.60 & 16.31 & 31.36 & 44.49 & 1.063 & 4.08 & ندرة الدورات الفنبة التخصصية لمعلمات رياض الأطفال & Tई \\
\hline 3 & 82.75 & .000 & 14.237 & 02.12 & 03.60 & 17.80 & 31.36 & 45.13 & .973 & 4.14 & ضعف التدريب في مجال تكنولوجيا المعلومات & 10 \\
\hline
\end{tabular}




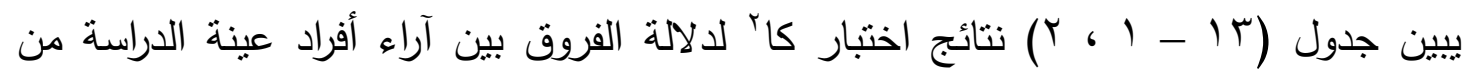

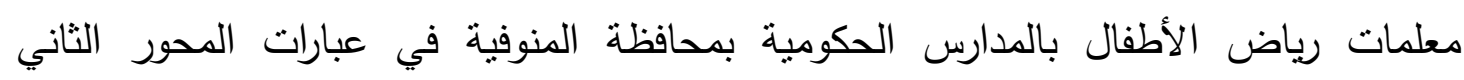

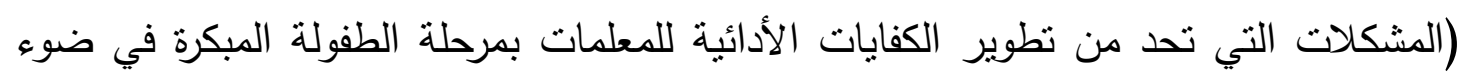

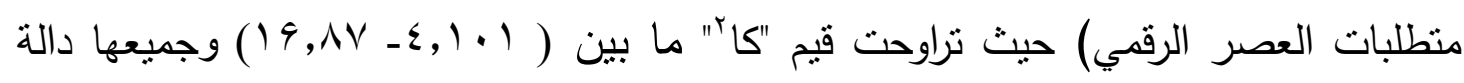

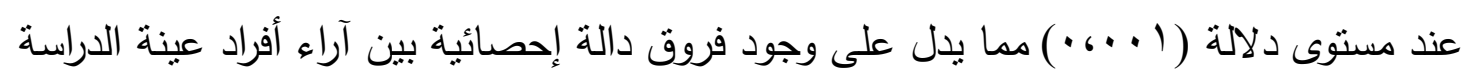
لصالح الرأي "موافق" لجميع العبارات. مناقشة نتائج المحور الثاني: " المشكلات التي تحد من تطوير الكفايات الأدائية للمعلمات

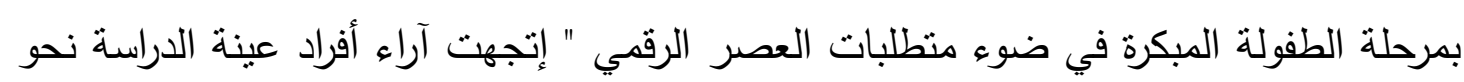

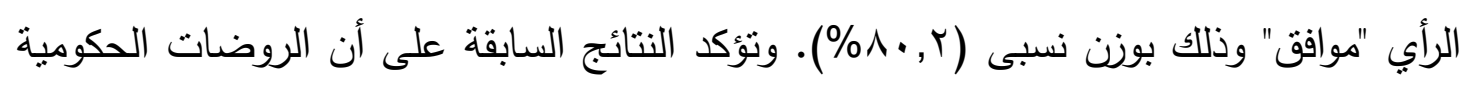

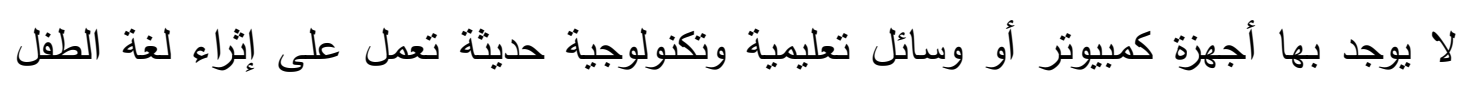

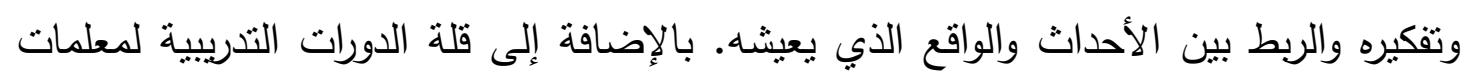

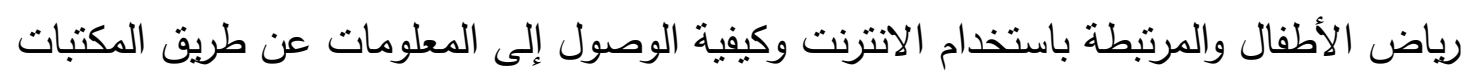

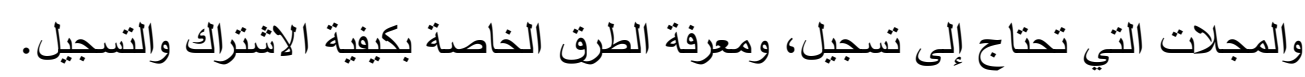

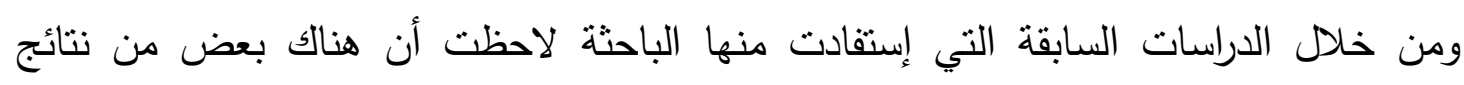

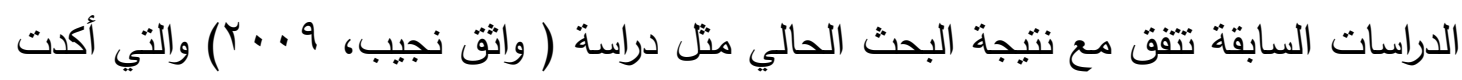

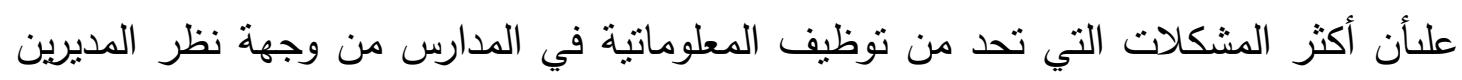

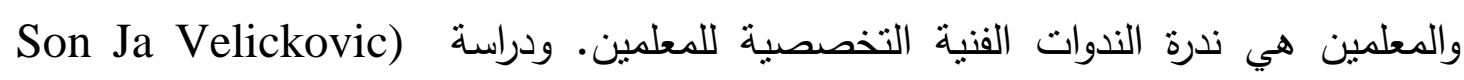
Lazor Stosic

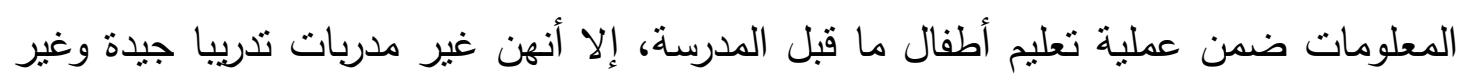

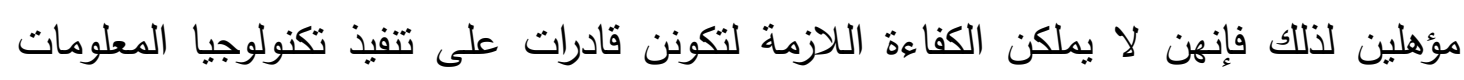

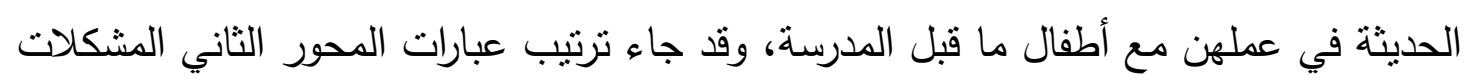

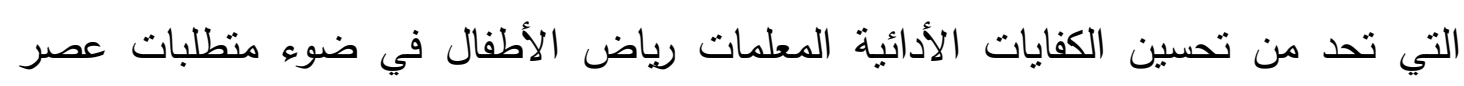

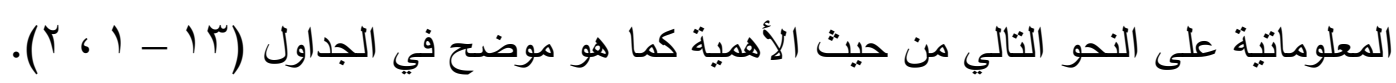

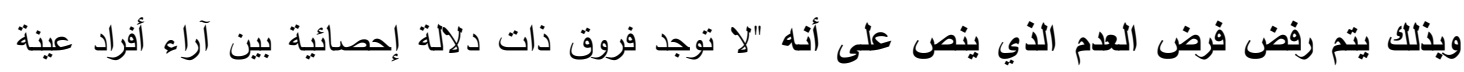

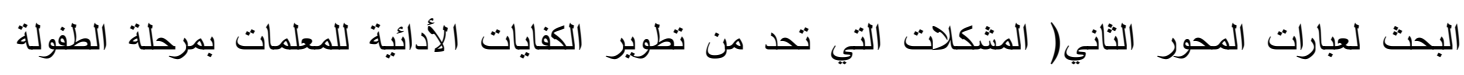

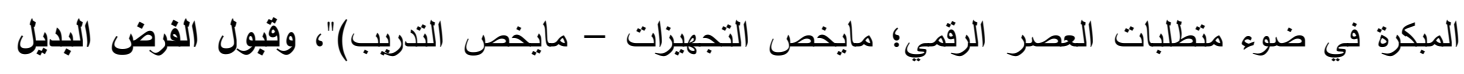

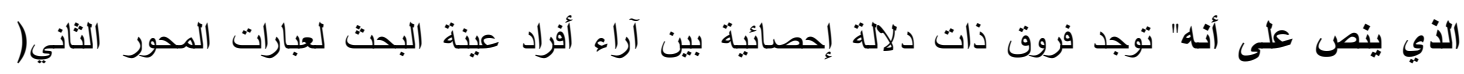

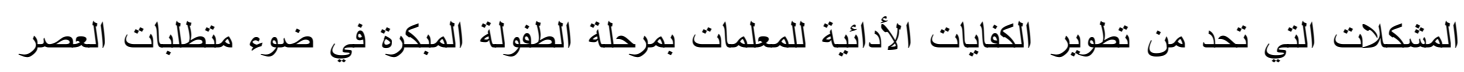
الرقمي؛ مايخص التجيزات - مايخص التنريب)". 
جدول ( اء - ا ) يوضح نتائج اختبار (كاّ) لدلالة الفروق بين آراء أفراد عينة الدراسة في عبارات المحور الثالث: آليات تطوير الكفايات الأدائية للمعلمات بمرحلة الطفولة المبكرة في

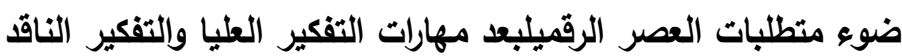

\begin{tabular}{|c|c|c|c|c|c|c|c|c|c|c|c|c|}
\hline \multirow{3}{*}{ الترتيب } & \multirow{3}{*}{ النسبي\% } & \multirow{3}{*}{ مستوي } & \multirow{3}{*}{ Sil } & موافق بثدة & غوافير & $\begin{array}{c}\text { أعرف } \\
\text { أعر }\end{array}$ & 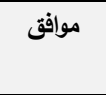 & موافق & \multirow{3}{*}{ المعياري } & \multirow{3}{*}{ المرجح } & \multirow{3}{*}{ 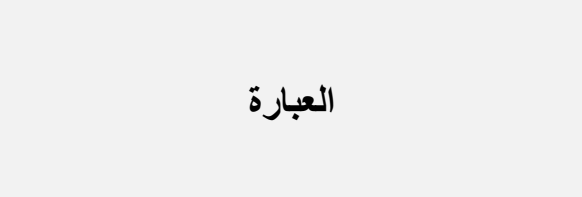 } & \multirow{3}{*}{$\hat{2}$} \\
\hline & & & & \multicolumn{5}{|c|}{ نسبة التكرار على المقياس } & & & & \\
\hline & & & & $\%$ & $\%$ & $\%$ & $\%$ & $\%$ & & & & \\
\hline 4 & 81.40 & .000 & 11.556 & 00.64 & 12.92 & 11.44 & 28.81 & 46.19 & 1.071 & 4.07 & القدرة على نوظيف المعلومات في حل المشكلات & 1 \\
\hline 1 & 92.67 & .000 & 31.085 & 00.42 & 02.12 & 10.81 & 06.99 & 79.66 & .792 & 4.63 & القدرة على اختبار المعلومات النافعة & $r$ \\
\hline 5 & 79.45 & .000 & 9.059 & 04.87 & 04.03 & 24.15 & 22.88 & 44.07 & 1.133 & 3.97 & القدرة على نقد المعلومات وتفسيرها & $\mu$ \\
\hline 2 & 88.22 & .000 & 20.708 & 02.12 & 04.03 & 08.69 & 20.97 & 64.19 & .956 & 4.41 & القدرة على استخدام المعلومات في انتاج أفكار جديدة & $\varepsilon$ \\
\hline 3 & 83.77 & .000 & 13.791 & 03.39 & 06.57 & 11.02 & 25.85 & 53.18 & 1.085 & 4.19 & امتلالك مهارات التفكير العلمي والابتكاري & 0 \\
\hline
\end{tabular}

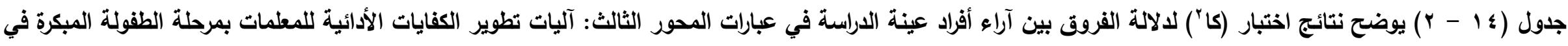
ضوء متطلبات العصر الرقميلبعد المهارات الحياتية

\begin{tabular}{|c|c|c|c|c|c|c|c|c|c|c|c|c|}
\hline \multirow[b]{3}{*}{ الترتيب } & \multirow{3}{*}{ النسبي\% } & \multirow{3}{*}{ مستولة } & \multirow{3}{*}{ كاי } & موافق بثدة & غوافير & $\begin{array}{c}\text { أعرف } \\
\end{array}$ & موافق & موافق & \multirow{3}{*}{ الانحراف } & \multirow{3}{*}{ المرجح } & \multirow{3}{*}{ 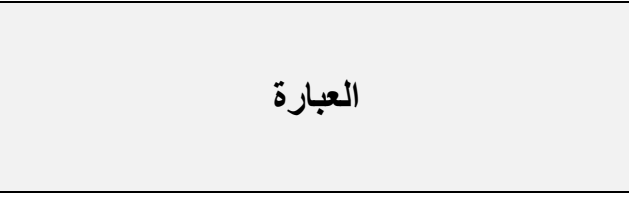 } & \multirow[t]{3}{*}{ 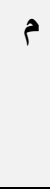 } \\
\hline & & & & \multicolumn{5}{|c|}{ نسبة التكرار على المقياس } & & & & \\
\hline & & & & $\%$ & $\%$ & $\%$ & $\%$ & $\%$ & & & & \\
\hline 3 & 91.69 & .000 & 28.475 & 01.27 & 02.75 & 06.14 & 15.89 & 73.94 & .828 & 4.58 & امتلاكمهاراتالتعلمالذاتي & 7 \\
\hline 4 & 86.69 & .000 & 19.507 & 01.06 & 03.18 & 16.10 & 20.55 & 59.11 & .930 & 4.33 & التعاملبإيجابيةمعالمتغيراتوالمستجداتالعالمية & V \\
\hline 5 & 83.94 & .000 & 15.085 & 02.54 & 03.18 & 17.58 & 25.42 & 51.27 & 1.004 & 4.20 & القدرة مراعاة خصائص الأطفال والفروق الفردية بينهم & $\wedge$ \\
\hline 1 & 95.76 & .000 & 47.309 & 00.21 & 00.85 & 05.30 & 07.20 & 86.44 & .592 & 4.79 & القدرة على التعامل مع الأزمات والمواقف الضاغطة & 9 \\
\hline 6 & 77.58 & .000 & 6.807 & 04.24 & 11.02 & 21.40 & 19.28 & 44.07 & 1.210 & 3.88 & التمكن من مهارات إدارة الوقت بفاعلية & 1 . \\
\hline 2 & 92.92 & .000 & 29.844 & 01.48 & 02.33 & 07.42 & 07.63 & 81.14 & .834 & 4.65 & القدرة على مواجهة التحديات التي يفرضها العصر الرقمي & 11 \\
\hline
\end{tabular}


جدول (؛ ا - "r) يوضح نتائج اختبار (كا") لالالة الفروق بين آراء أفراد عينة الدراسة في عبارات الدحور الثالث: آليات تطوير الكفايات الأدائية للمطلمات بمرطلة الطفولة المبكرة في

ضوء متطلبات العصر الرقميلبعد توظيف التكنولوجيا

\begin{tabular}{|c|c|c|c|c|c|c|c|c|c|c|c|c|}
\hline \multirow{3}{*}{ الترتيب } & \multirow{3}{*}{ النسبي\% } & \multirow{3}{*}{ مستوية } & \multirow{3}{*}{ كاי } & موافق بشدة & غوافير & $\begin{array}{c}\text { أعرف } \\
\end{array}$ & موافق & موافق & \multirow{3}{*}{ المعياري } & \multirow{3}{*}{ المرجح } & \multirow{3}{*}{ 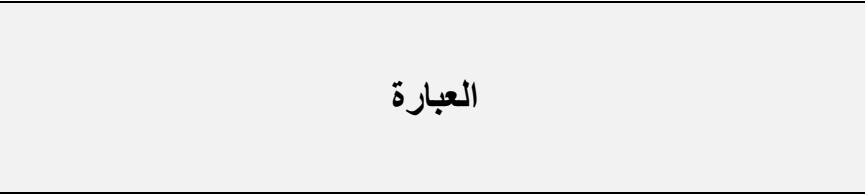 } & \multirow{3}{*}{ b } \\
\hline & & & & \multicolumn{5}{|c|}{ نسبة التكرار على المقياس } & & & & \\
\hline & & & & $\%$ & $\%$ & $\%$ & $\%$ & $\%$ & & & & \\
\hline 8 & 79.15 & .000 & 8.589 & 01.48 & 13.14 & 20.76 & 17.37 & 47.25 & 1.158 & 3.96 & القدرة على جمع المعلومات وتصنيفها & ir \\
\hline 6 & 83.31 & .000 & 13.714 & 02.12 & 05.51 & 19.28 & 19.92 & 53.18 & 1.054 & 4.17 & التمكن من مفاهيم ومصطلحات تكنولوجيا المعلومات & $1 T$ \\
\hline 1 & 88.26 & .000 & 21.252 & 01.27 & 04.45 & 10.38 & 19.49 & 64.41 & .933 & 4.41 & القدرة على تصميم قاعدة بيانات & $1 \leqslant$ \\
\hline 7 & 81.40 & .000 & 12.231 & 01.06 & 09.11 & 14.19 & 33.05 & 42.58 & 1.012 & 4.07 & القدرة على تصميم البرمجيات التعليمية & 10 \\
\hline 4 & 85.64 & .000 & 18.171 & 02.12 & 02.75 & 12.50 & 30.08 & 52.54 & .935 & 4.28 & التمكن من مهارات الاتصال الالكتروني & 17 \\
\hline 5 & 84.83 & .000 & 16.329 & 02.12 & 04.03 & 14.62 & 26.06 & 53.18 & .987 & 4.24 & القدرة على الاتصال بالمكتبات ومصادر المعلومات المختلفة & IV \\
\hline 2 & 88.05 & .000 & 21.673 & 00.85 & 03.18 & 14.19 & 18.43 & 63.35 & .905 & 4.40 & امتلاك مهارة البحث عن المعلومات في الإنترنت & 11 \\
\hline 3 & 86.69 & .000 & 18.825 & 01.48 & 03.60 & 15.47 & 18.86 & 60.59 & .963 & 4.33 & التمكن من مهارة تشغيل الملفات الصوتية والفيديو باستخدام البرامج المناسبة لها & 19 \\
\hline
\end{tabular}




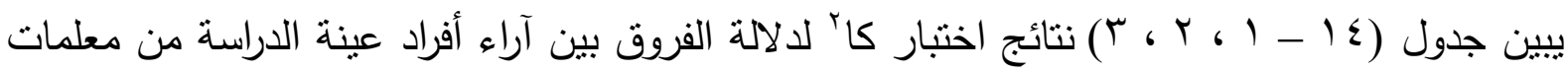

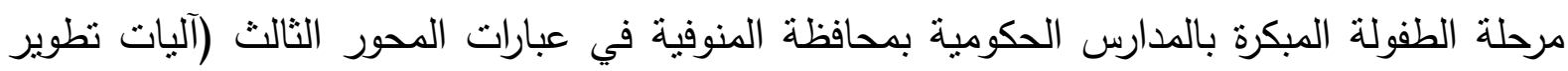

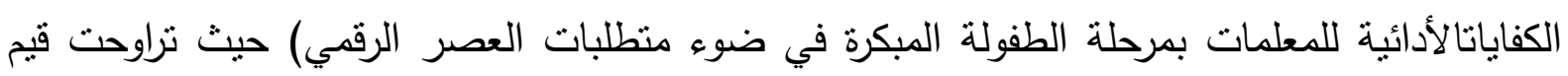

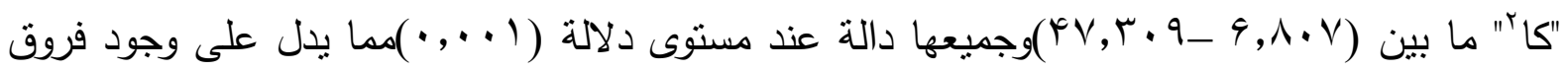

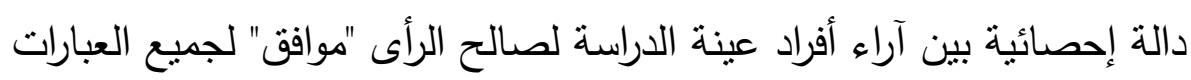

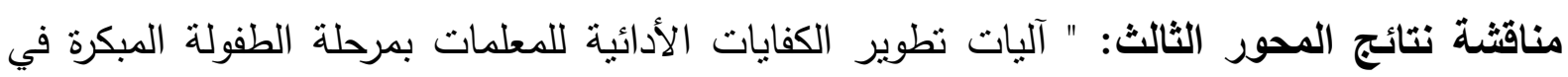

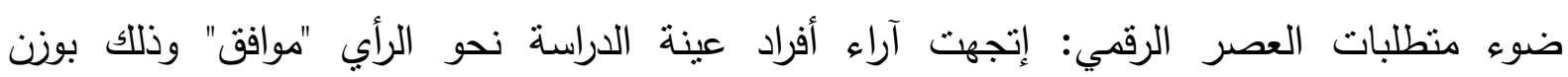

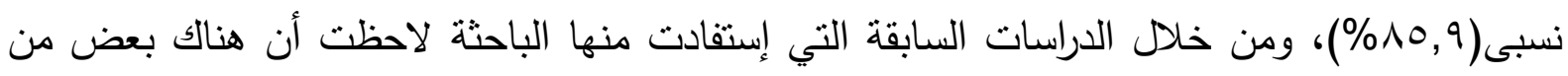

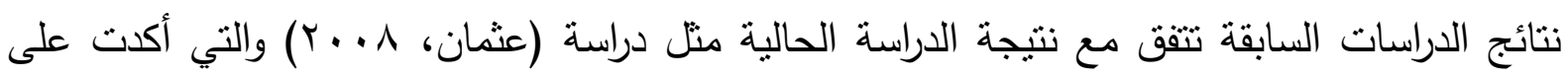
إمكانية صياغة إستراتيجية تعليمية أكثر شمولا وأوسع تأثنرا تمكن من التعامل بوعي مخطط مع التطور

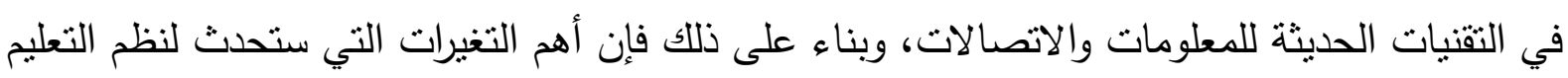

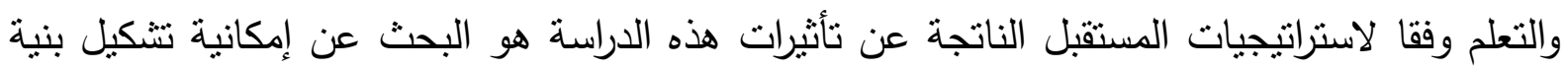

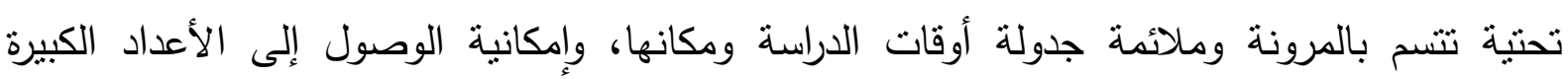

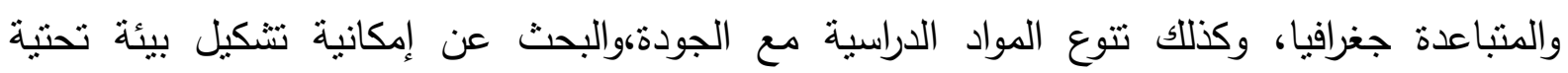

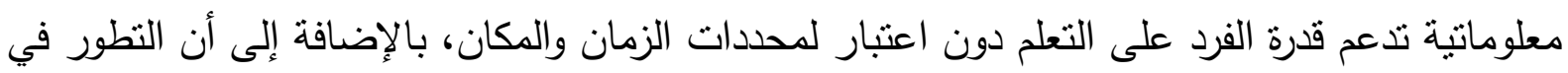
وسائل الاتصال وتقنية المعلومات ينبئ بظهور أنماط جديدة من النظم التربوية والتعليمية التقنية. ودراسة( Caltay Baran،2006 ) والتي أكدت على وجود علاقة إيجابية قوية بين التطوير المهني

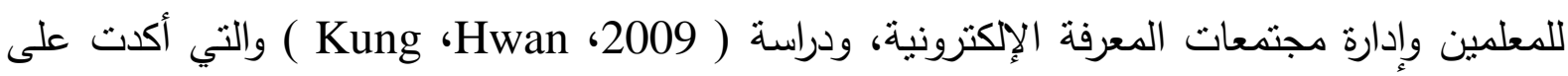

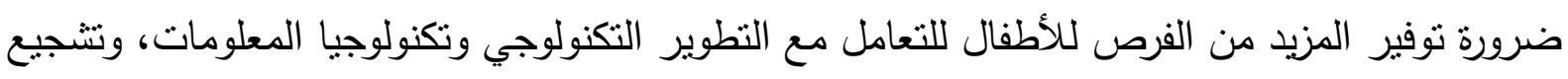

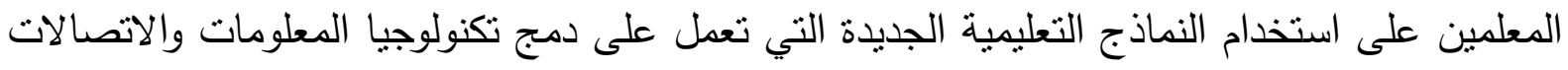

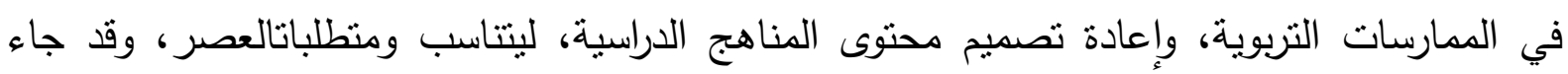

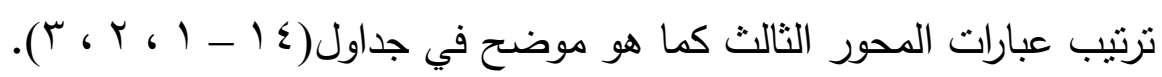
ويذلك يتم رفض فرض العدم الأي ينص على أنه: "لا توجد فروق ذات دلاتلة دلات إحصائية بين آراء أفراد

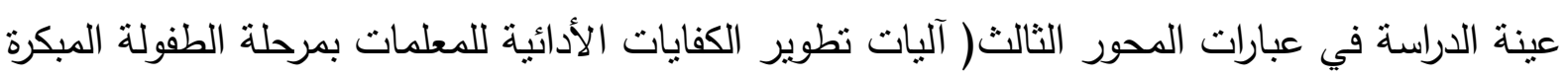

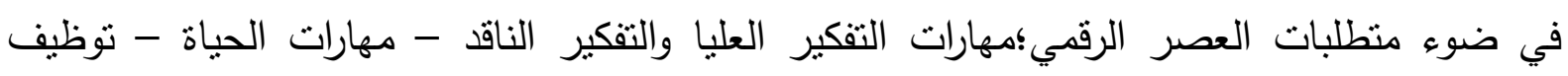
التكنولوجيا)"، وقبول الفرض البديل الذي ينص على أنه: "توجد فروق ذات دلالة إحصائية بين آراء أفراد

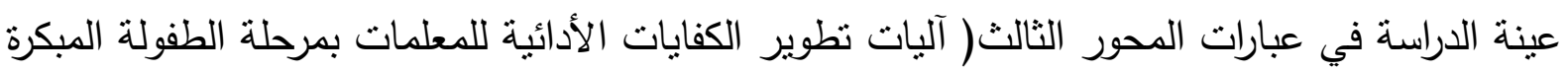

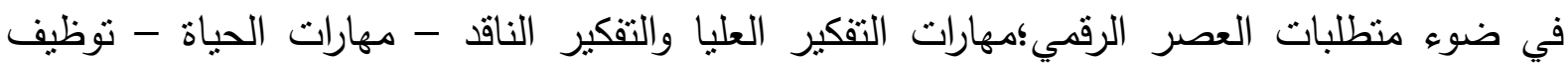
التكنولوجيا)". 
جدول (10)

نتائج إختبار (ت)؛ لبيان دلالة الفروق بين محاور الاستبانة وأبعادها المختلفة في متغيري الريف والحضر

\begin{tabular}{|c|c|c|c|c|c|c|}
\hline \multirow[b]{2}{*}{ الدلالة } & \multirow[b]{2}{*}{ 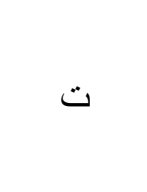 } & \multicolumn{2}{|c|}{ ريف } & \multicolumn{2}{|c|}{ حضر } & \multirow[b]{2}{*}{ المحاور } \\
\hline & & الالنحراف & المتوسط & الانحراف & 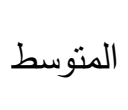 & \\
\hline 265 & 1.116 & 0.617 & 3.815 & 0.566 & 3.877 & واقع ممارسة الكفايات الأدائية للمطلمات \\
\hline .578 & .557 & 0.919 & 4.039 & 0.873 & 4.086 & كفايات التخطيط \\
\hline .228 & 1.207 & 0.580 & 3.732 & 0.665 & 3.801 & كفايات التنفيذ \\
\hline 195 & 1.298 & 0.562 & 3.674 & 0.592 & 3.743 & كفايات التقويم \\
\hline 190 & 1.314 & 0.752 & 3.985 & 0.615 & 4.070 & الأدائية للمعلمات التي تحد من تطوير الكفايات الطفي \\
\hline .527 & -.632 & 0.815 & 3.982 & 0.808 & 3.935 & مايخص التجهيزات \\
\hline .003 & 2.959 & 0.881 & 3.989 & 0.661 & 4.207 & ما يخص الندريب \\
\hline 468 & -.727 & 0.551 & 4.328 & 0.553 & 4.291 & بمرحلة الطفولة المبكرة في ضوير الكفايات الأدائية للمعلمات \\
\hline .864 & 172 & 0.708 & 4.262 & 0.728 & 4.274 & مهارات التفكير العليا والتفكير الناقد \\
\hline .385 & -.870 & 0.567 & 4.425 & 0.598 & 4.378 & المهارات الحياتية \\
\hline 189 & -1.315 & 0.618 & 4.297 & 0.643 & 4.220 & توظيف التكنولوجيا \\
\hline
\end{tabular}

يتضح من جدول (10) السابق أنه لا توجد فروق ذات دلالة احصائية بين محاور الاستبانة وأبعادها

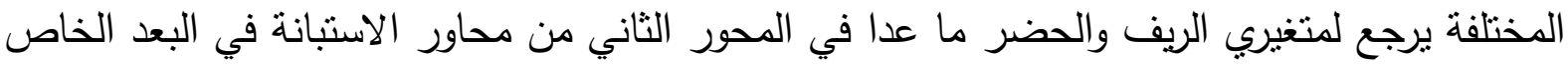
بالتدريب فهناك دلالة قوية لصالح الحضر؛ وقد أرجعت الباحثة ذلك إلى اهتمام وزارة التربية والتعليم بالتنريب المستمر لجميع المدارس بالإدارات المختلفة بمحافظة المنوفية، وبالنسبة للحضر فإن إنقافة

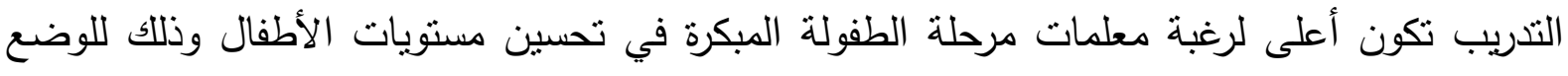

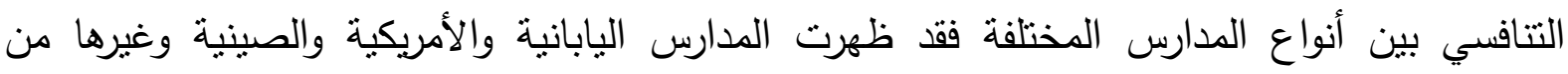

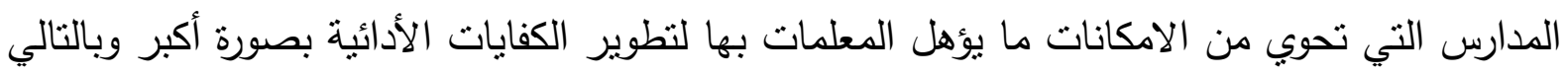
تهتم المعلمات بالمدارس الحكومية بالحضر بجانب التنريب لنواكب الوضع التتافسي لتلاك المدارس. ويذلك يتم رفض فرض العدم الأي ينص على أنه: "لا توجد فروق ذات دلالة احصائية بين محاور

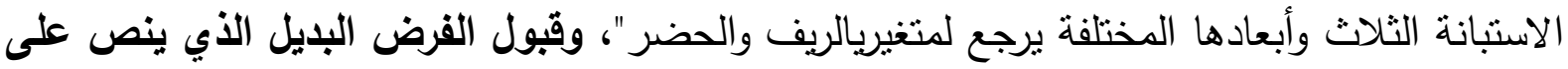


أنهاتوجد فروق ذات دلالة احصائية بين محاور الاستبانة الثناث وأبعادها المختلفة يرجع لمتغيري الريف والحضر".

جدول (7 1 ) معاملات ارتباط بيرسون لبيان مصفوفة الارتباطبين محاور وأبعاد الاستبانة

\begin{tabular}{|l|c|c|c|c|c|c|c|c|c|c|c|}
\hline \multicolumn{1}{c|}{$\mathrm{c} 3$} & \multicolumn{1}{c|}{$\mathrm{c} 2$} & $\mathrm{c} 1$ & $\mathrm{~b} 2$ & $\mathrm{~b} 1$ & $\mathrm{a} 3$ & $\mathrm{a} 2$ & $\mathrm{a} 1$ & $\mathrm{c}$ & $\mathrm{b}$ & $\mathrm{a}$ & \\
\hline $.463^{* *}$ & $.445^{* *}$ & $.461^{* *}$ & $.747^{* *}$ & $.618^{* *}$ & $.792^{* *}$ & $.894^{* *}$ & $.866^{* *}$ & $.532^{* *}$ & $.789^{* *}$ & 1 & $\mathrm{a}$ \\
\hline $.356^{* *}$ & $.365^{* *}$ & $.344^{* *}$ & $.863^{* *}$ & $.867^{* *}$ & $.543^{* *}$ & $.699^{* *}$ & $.739^{* *}$ & $.412^{* *}$ & 1 & & $\mathrm{~b}$ \\
\hline $.856^{* *}$ & $.850^{* *}$ & $.870^{* *}$ & $.429^{* *}$ & $.285^{* *}$ & $.475^{* *}$ & $.606^{* *}$ & $.337^{* *}$ & 1 & & & $\mathrm{c}$ \\
\hline $.277^{* *}$ & $.350^{* *}$ & $.250^{* *}$ & $.631^{* *}$ & $.647^{* *}$ & $.446^{* *}$ & $.635^{* *}$ & 1 & & & & $\mathrm{a} 1$ \\
\hline $.521^{* *}$ & $.459^{* *}$ & $.570^{* *}$ & $.720^{* *}$ & $.490^{* *}$ & $.711^{* *}$ & 1 & & & & & $\mathrm{a} 2$ \\
\hline $.446^{* *}$ & $.343^{* *}$ & $.427^{* *}$ & $.560^{* *}$ & $.380^{* *}$ & 1 & & & & & & $\mathrm{a} 3$ \\
\hline $.257^{* *}$ & $.331^{* *}$ & $.165^{* *}$ & $.496^{* *}$ & 1 & & & & & & & $\mathrm{~b} 1$ \\
\hline $.360^{* *}$ & $.300^{* *}$ & $.432^{* *}$ & 1 & & & & & & & & $\mathrm{~b} 2$ \\
\hline $.592^{* *}$ & $.605^{* *}$ & 1 & & & & & & & & & $\mathrm{c} 1$ \\
\hline $.625^{* *}$ & 1 & & & & & & & & & & $\mathrm{c} 2$ \\
\hline 1 & & & & & & & & & & & $\mathrm{c} 3$ \\
\hline
\end{tabular}

*** دالة عند مستوى معنوية ( ألفا = ( •, • ) حيث : إن:

a $=a$

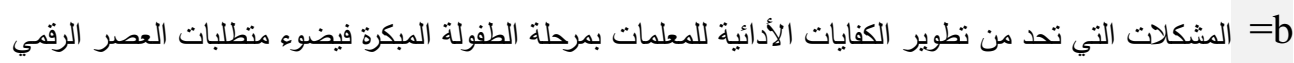

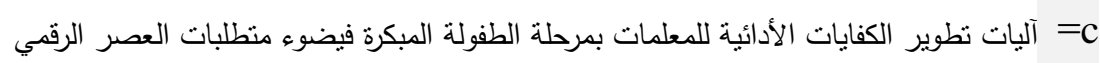

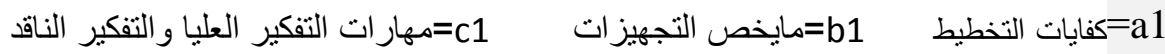

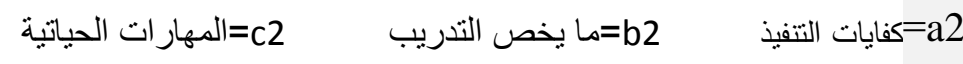

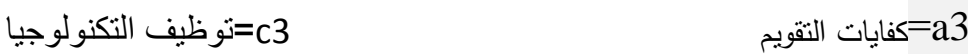

يتضح من جدول (T ())السابق وجود علاقة ارتباط موجبة ذات دلالة معنوية بين أبعاد الاستبانة ومحاورها

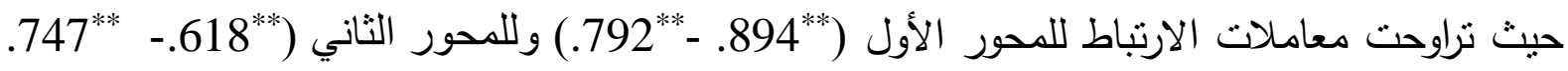
) وللمحور الثالث (***4. - 463.*. )وذلك يدل على أهمية مرحلة التخطيط للمعلمات بمرحلة الطفولة المبكرة فزيادة قدرة المعلمة على التخطيط واتقانها لهذه المرحلة يزبد من قدرتها وفعاليتها في مرحلتي التتفيذ والتقويم، وأيضاً قوة الارتباط في المحور التاني على أنه كلما كانت التجهيزات متوفرة زادت فاعلية التدريب وبالتالي تزبد كفاءة المعلمات، والمحور الثالث الذي يتتاول متطلبات العصر الرقمي تشير الى ارتباط الأبعاد والمهارات المختلفة للعصر الرقمي بجميع منطلباته مما يزبد من كفاءة وقدرات المعلمات بمرحلة الطفولة المبكرة مما ينعكس ايجابياً على الطفل في مرحلة الطفولة المبكرة. ويذلك يتم رفض فرض العدم الأي ينص على أنه: " لا توجد علاقة ارتباط ذات دلالة احصائية محاور الاستبانة الثلاث وأبعادها المختلفة"، وقبول الفرض البديل الأي ينص على أنه: " توجد علاقة ارتباط ذات دلالة احصائية محاور الاستبانة الثناث وأبعادها المختلفة". 


\section{نتائج البحث:}

ا-توجد فروق ذات دلالة إحصائية بين آراء أفراد عينة البحث في عبارات المحور الأول (واقع

ممارسة الكفايات الأدائية للمعلمات بمرحلة الطفولة المبكرة؛ كفايات التخطيط - التنفيذ -

(التقوبم)

ץ-توجد فروق ذات دلالة إحصائية بين آراء أفراد عينة البحث لعبارات المحور الثاني(

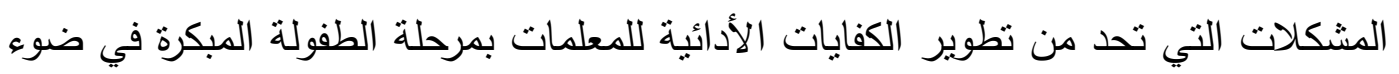

متطلبات العصر الرقمي؛ مايخص التجهيزات - مايخص التدريب)

ب-توجد فروق ذات دلالة إحصائية بين آراء أفراد عينة الدراسة في عبارات المحور الثالث(

آليات تطوير الكفايات الأدائية للمعلمات بمرحلة الطفولة المبكرة في ضوء متطلبات العصر

الرقمي؛مهارات التفكير العليا والتفكير الناقد - مهارات الحياة - توظيف التكنولوجيا)

ع- توجد فروق ذات دلالة احصائية بين محاور الاستبانة الثلاث وأبعادها المختلفة يرجع

لمتغيري الربف والحضر • مان

0-توجد علاقة ارتباط ذات دلالة احصائية بين محاور الاستبانة الثناث وأبعادها المختلفة

الصعويات التي واجهت الباحثة عند إجراء الدراسة الميدانية:

واجهت الباحثة بعض الصعوبات أهمها:

- وجود عينة البحث في إدارات تعليمية مختلفة، مما استلزم الجهد والإرهاق.

- ضعف مشاركة بعض أفراد العينة بإبداء الرأي والمقترحات في بعض العباته العبهات.

- كثرة التردد على أفراد العينة لجمع الاستبانات وهم في أماكن بعيدة ومتفرقة. - عدم جدية بعض أفراد العينة.

ولكن بوجه عام كان هناك عدد كبير من أفراد العينة متميزين ومتعاونين وأولوا عملية تطبيق الاستبانة اهتماماً كبيراً حيث أعجب كثير منهم بموضوع البحث. هناك. ثانيا: التصور المقترحملحق (3):في ضوء النتائج السابقة حاولالبحث وضع تصور مقترح لتطوير الكفايات الأدائية للمعلمات بمرحلة الطفولة المبكرة في ضوء متطلبات العصر الرقمي، والذي يشمل ما يلي:المنطلقات الفكرية للتصور المقترح، الركائز التي بني عليها التصور المقترح، أهداف التصور المقترح، خصائص التصور المقترح،آليات تتفيذ التصور المقترح، النتائج المتوقعة من تتفيذ التصور المقترح، المعوقات المنوقعة أمام تتفيذ التصور المقترح، مقترحات للتغلب على المعوقات التي تواجه التصور المقترح،وفيما يلي عرض لهذا التصور المقترح: المنطلقات الفكرية للتصور المقترح:إن تطوير الكفايات الأدائية للمعلمات بمرحلة الطفولة المبكرة في ضوء منطلبات العصر الرقمي عملية لا تعتمد على العشوائية ويترتب نجاحها على خطة متكاملة نتطلق

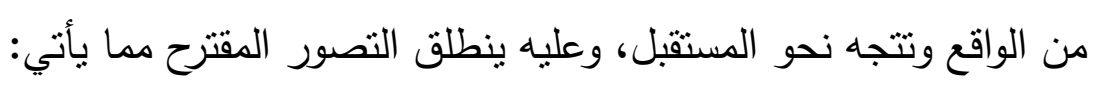


- - تمثل الطفولة المبكرة مرحلة مهمة من النظام التعليمي وبحاجة لمزيد من التطوير في مجال المعلمات وبصفة خاصة الكفايات الأدائية لتصبح قوبية وفعالة ومتطورة .

- يتوقف نجاح منظومة التعليمبرياض الأطفال على مجموعة من العوامل من أهمها نشخيص نواحي الضعف والحاجات التعليمية لمعلمات هذه المرحلة. - الاهتمام بالتتمية المهنية للمعمات من خلال إجراء تدريبات دورية قبل الخدمة وإثتائها عن

$$
\begin{aligned}
& \text { الاتجاهات الحديثة في التعليم والتدريس. } \\
& \text { ركائز بناء التصور المقترح : }
\end{aligned}
$$

- مرق تطوير الكفايات الأدائية للمعلمات . - - الخصائص العمرية والنمائية لمرحلة الطفولة المبكرة. - - الأدبيات الحديثة في الكفايات الأدائية بصفة عامة، وفي رياض الأطفال بصفة خاصة. - - نتائج الدراسة الميدانية. - الروئة الخاصة للباحثة.

أهداف التصور المقترح:تتمثل أهداف التصور في وضع آليات تتفيذية لتطوير الكفايات الأدائية للمعلمات بمرحلة الطفولة المبكرة. خصائص التصور المقترح:حتى يحقق التصور أهدافه، من المهم أن يتصف بعدة سمات تسهم في نجاحه وتجعله أكثز فاعلية.

متطلبات تحقيق التصور المقترح :يمكن تحقيق التصور المقترح من خلال تتفيذ عدد من الآليات . المعوقات المتوقعة أمام تنفيذ التصور المقترح :هناك عدد من المعوقات المتوقع حدوثها عند تتفيذ التصور المقترح مقترحات للتقلب على المعوقات التي قد تواجه تنفيذ التصور المقترح: تقدم الباحثة عدد من المقترحات للتغلب على المعوقات التي قد تواجه نتفيذ التصور المقترح توصيات البحث: - عقد دورات تدربيية مكثقة لمعلمات الطفولة المبكرة لإثراء أفكارهن بأمنلة وتدريبات وتطبيقات تربوية بسيطة ومثيرة وتزويدهن بالأدوات والأجهزة اللازمة لكل تدريب والعمل على تحضيرها قبل القيام بها. - - - ضرورة تكثيف الإشراف على معلمات الطفولة المبكرة ونزويدهن بكل جديدفي مجال التخصص. - إعادة النظر في برامج إعداد معلمات الطفولة المبكرة وتطويرها؛ لتواكب التطورات والتحديات التي تطرأ على العالم كل يوم. 
بحوث مقترحة: في ضوء ما نوصل إليه البحث من نتائج فإن هناك ضرورة لإجراء بعض البحوث

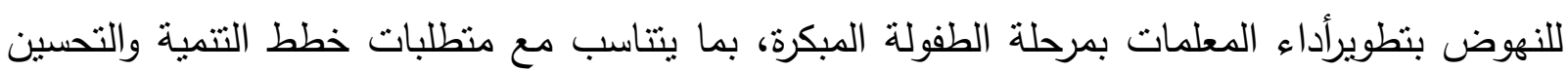

$$
\text { والتطوير ، ومن أهم هذه البحوث: }
$$

- تطويرأداء المعلمات بمرحلة الطفولة المبكرةفي ضوء التهون التجارباليابانية والأمريكية.

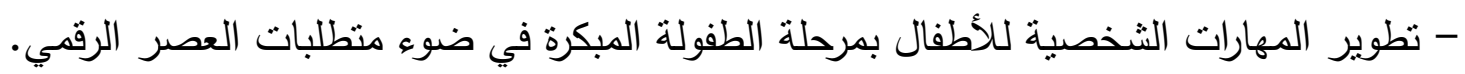

\section{قائمة المراجع:أولا: المراجع العربية:}

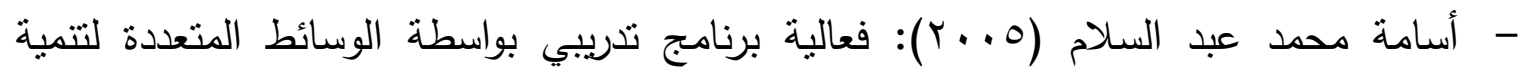

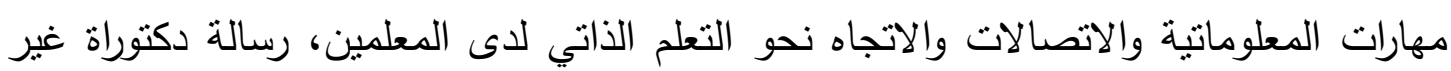

منشورة، معهد الدراسات والبحوث التربوية، جامعة القاهرة .

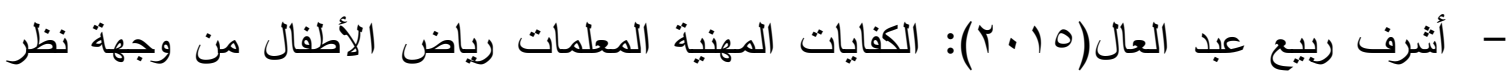
المديرين والموجهين التربوبين في ضوء معايير الجودة المصرية، رسالة ماجستير غير منشورة،

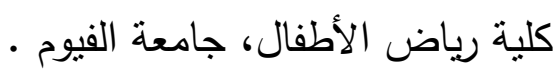

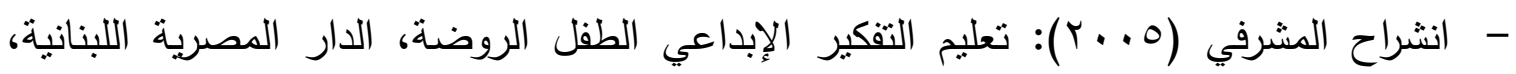

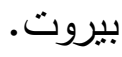

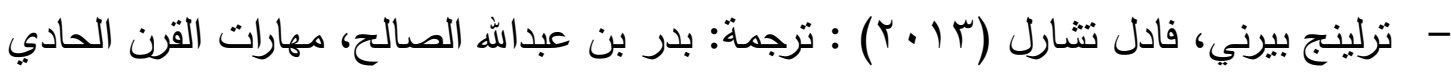

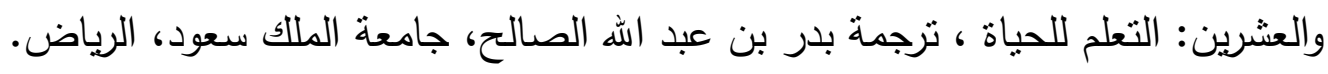

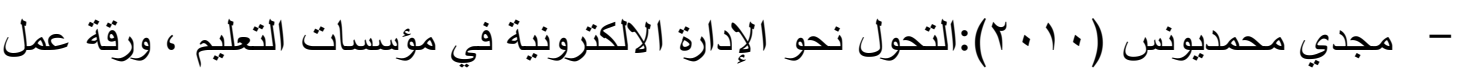

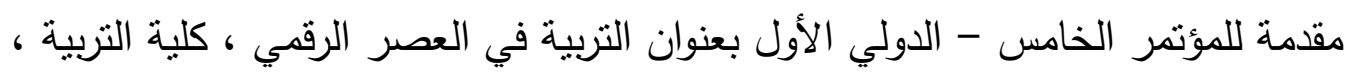
جامعة المنوفية، شبين الكوم.

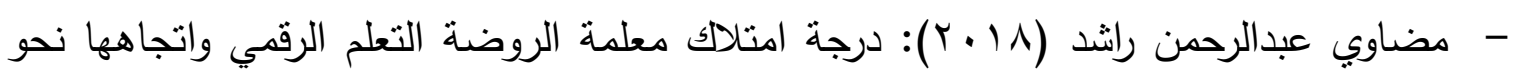

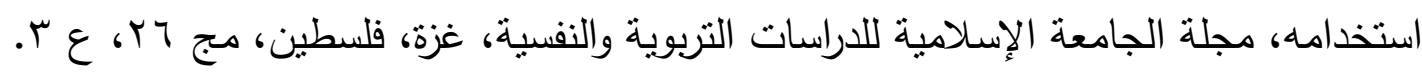

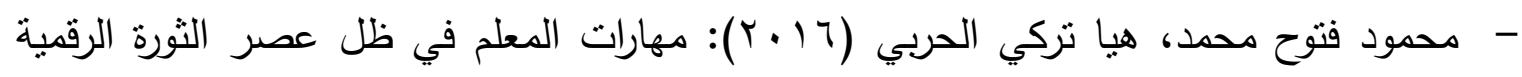

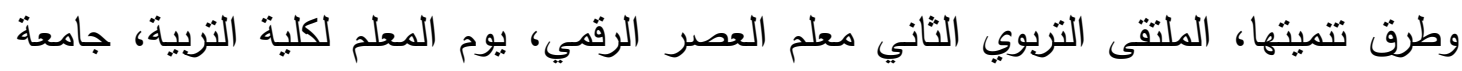

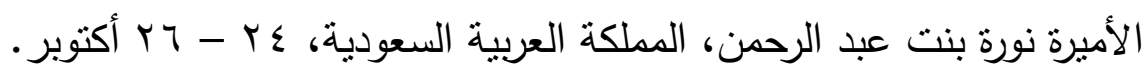

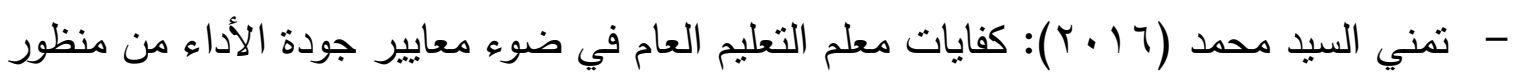

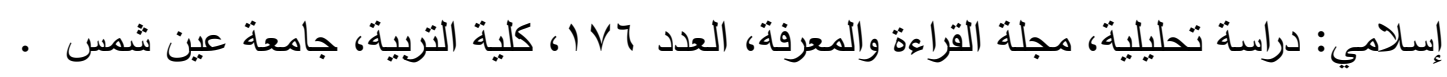

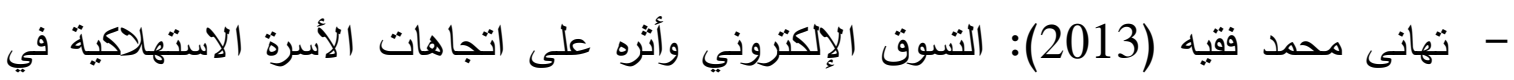

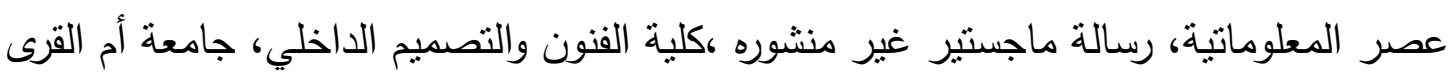

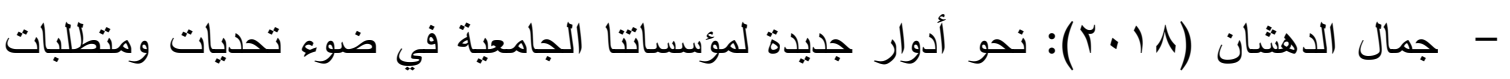




\section{العصر الرقمي، 14 http://pressst.com/?p=30002 مايو}

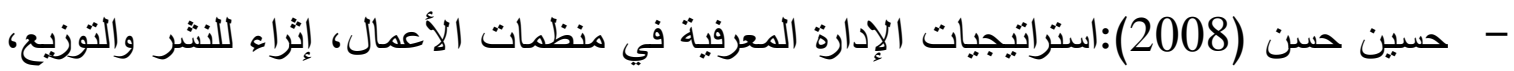
عمان حسين كامل بهاء الدين (2000): الوطنية في عالم بلا هوية- تحديات العولمة، دار المعارف،

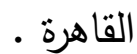

- حكيم خليفة المنتصر(2013): فعالية توظيف الحاسب في مدارس الثانويات التخصصية على دانى تحصيل الطلاب واتجاهاتهم نحو المعلوماتية، رسالة دكتوراة غير منشورة، معهذ الدراسات والبحوث التزبوية، جامعة القاهرة . - خلف على الصقرات (2007): تقويم أداء الطالبات المعلمات تخصص معلم صف في ضوء الكفايات التعليمية اللازمة للتدريس وبناء برنامج تدريبي مقترح وقياس فاعليته في جامعة مؤته،

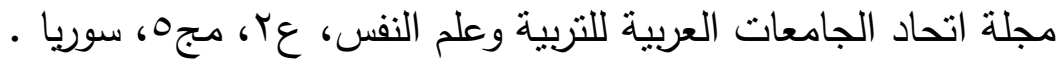

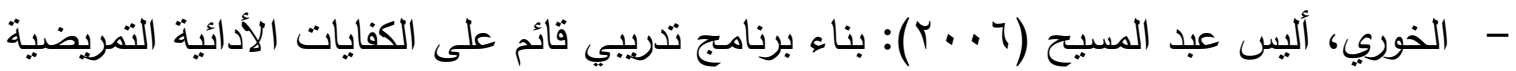

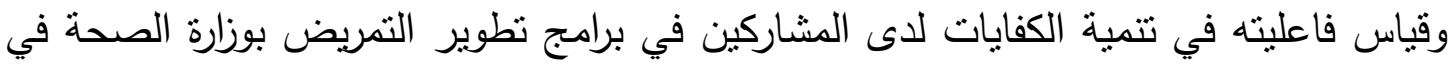

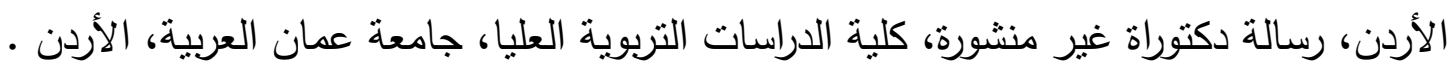

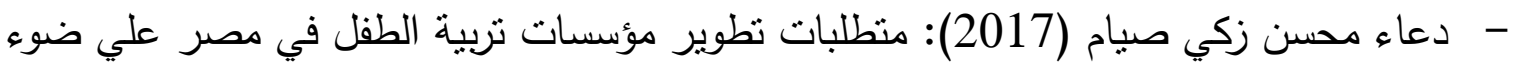
سمات المدارس صديقة الطفل، رسالة ماجستير غير منشورة، كلية النربية، جامعة دمياط.

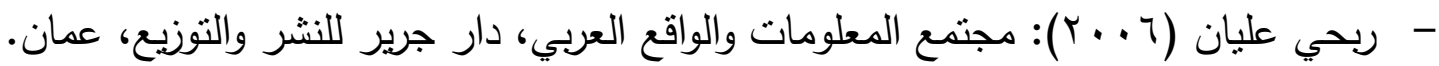

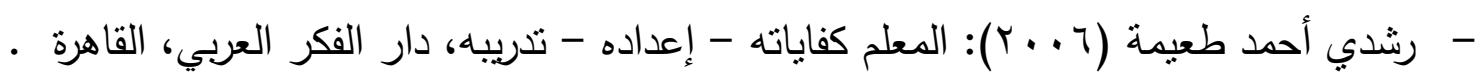

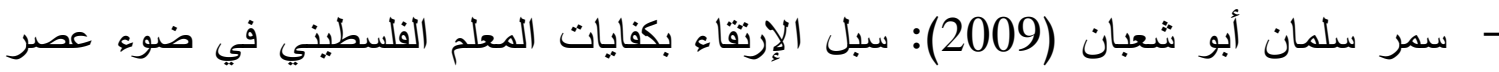

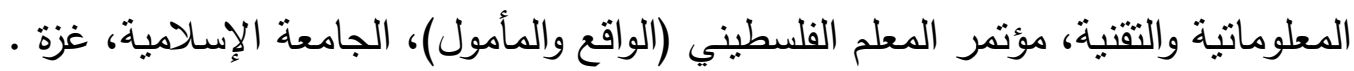
- سمير عبد الوهاب (2010): المفاهيم وتتميتها في رياض الأطفال، مكتبة نانسي، دمياط

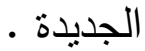
سوسن عبد الحميد محمد (10 ب): الكفايات الأدائية والاتجاه نحو التدريس لدى طالبات كلية التربية للبنات تخصص رياضيات، مجلة القراءة والمعرفة، كلية التربية، جامعة عين شمس . - السيد عبد القادر شريف (2008). التربية الاجتماعية والدينية في رياض الأطفال، دارالميسرة للطباعة والنشر، عمان.

- شكيب بشماني (§ ( ـ r): دراسة تحليلية مقارنة للصيخ المستخدمة في حساب حجم العينة العشوائية مجلة جامعة تشرين للبحوث والدراسات العلمية، سلسلة العلوم القتصادية والقانونية

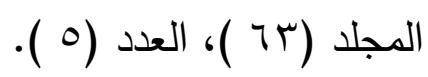

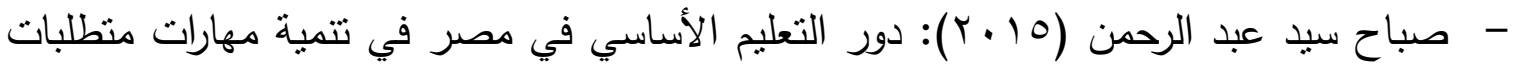


التعامل مع عصر المعلومات- تصور مقترح، مجلة رابطة التربية الحديثة، مج V، عجr، . القاهرة .

- طاهر عبد الكريم سلوم، عبد الجيد غالب المخلافي (2010). تقويم كفايات معلمي الدراسات الاجتماعية خريجي كلية التربية بجامعة السلطان قابوس من وجهة نظر المشرفين والمعلدين،

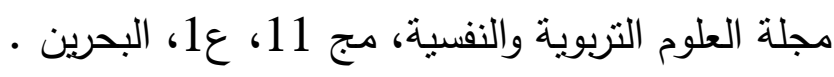
- - عبد الخالق فؤادعبد الخالق (2008): مدخل لرياض الأطفال، مكتبة المتتبي ، المملكة العربية الفية السعودية. - عبد الدحسن حمد العامري (10 • ؟): نقويم أداء مدرسي التربية الإسلامية في التعليم الأهلي في

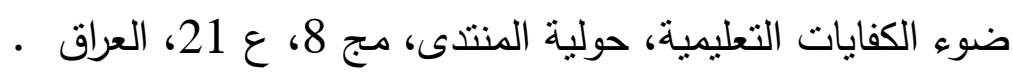

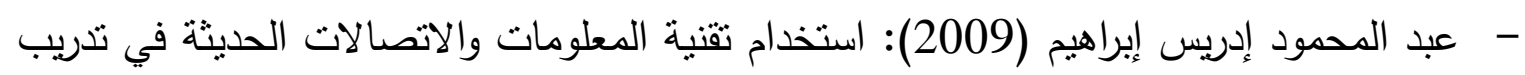

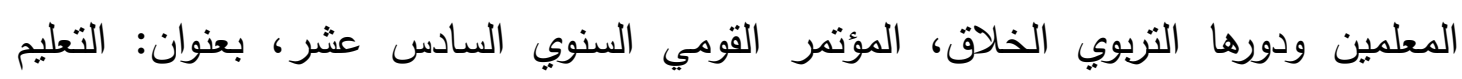

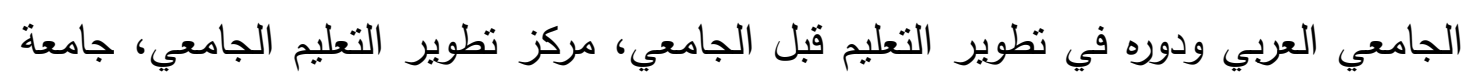
عين شمس . - عزيزة عبد الرحمن العتيبي (2010): أثر استخدام تكنولوجيا المعلومات على أداء الموارد

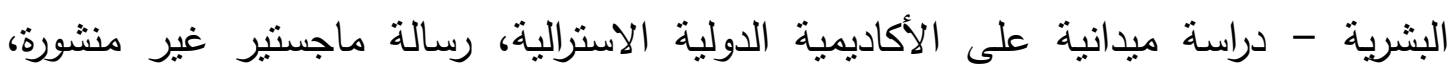
الأكاديمية العربية البريطانية للتعليم العالي، لندن.

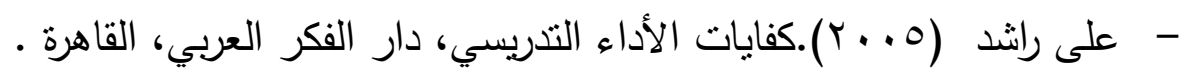

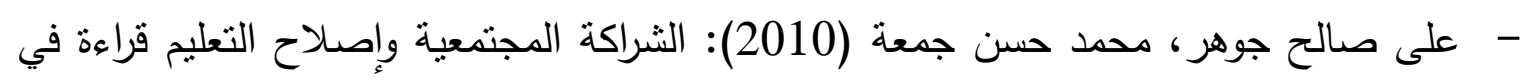

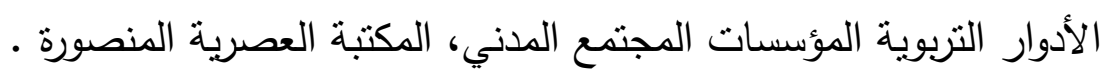

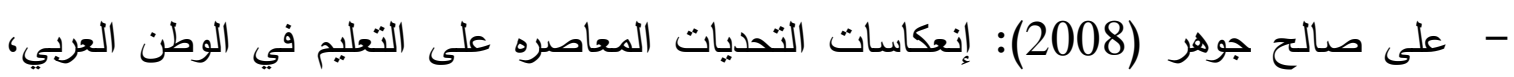
المكتبة العصرية، المنصورة . - علي عباس علي (2012): الكفاءة المنية المفضلة للأستاذ الجامعي من وجهة نظر طالباته،

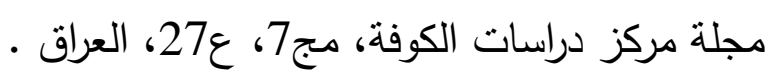
- علي عون (2011): الكفايات الثخصية والأدائية لدى معلمات التربية التحضيرية، مجلة العلة العلوم الانسانية والاجتماعية، ع\&، جامعة قاصدي مرباح، ورقلة، الجزائر.

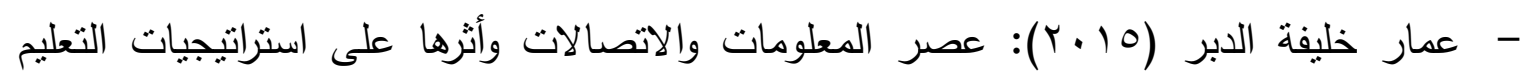
والتعلم، مجلة الجامعي، ع 21، النقابة العامة لأعضاء هيئة التدريس الجامعي، ليبيا.

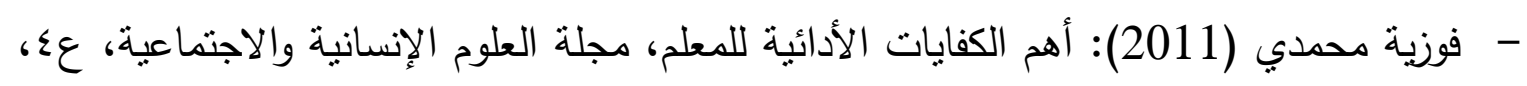
جامعة قاصدي مرباح، الجزائر · مان. - مايكل، ب. إيزنبيرج، وآخرون (2007): تعليم مهارات المعلوماتية والتكنولوجيا المهارات الست 
الكبرى في المدارس الإبتدائية، مجلة الطفولة العربية، مج8، ع آس، الكويت، يونيو . - مبروكة عمر محيريق (ع ( ب)): دور المؤسسات التعليمية في بناء مجتمع المعرفة المجلة الليبية للمكتبات والمعلومات والأرشيف، ع)، الجمعية الليبية للمكتبات والمعلومات والأرشيف، لييا، - يونيو - مجدي عزيز إبراهيم (2001): المنهج التربوي العالمي - أسس تصميم منهج نربوي في ضوء

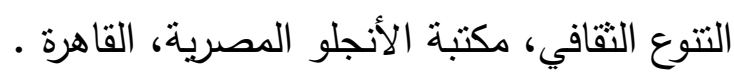
- محمد ابراهيم أمين، وليد ابراهيم عبد المقصود (2013): الكفايات الأدائية لهعلمي التربية

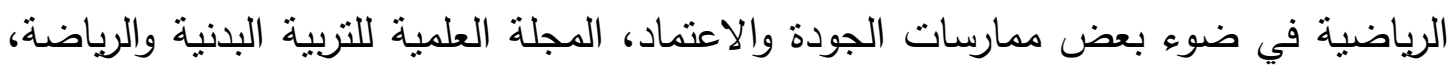
ع ع 79، القاهرة . - محمد حسين عبد الهادي أبو جاسر (2012): دور المشرف التربوي في تتمية كفايات تكنولوجيا المعلومات لمعلمي المرحلة الثانوية بفلسطين وفق المعايير الدولية، رسالة ماجستير غير منشورة،

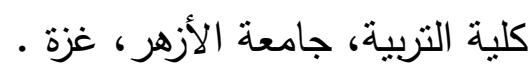
- محمد عباس عرابي (2013): أدوار المعلم في عصر المعلوماتية، مجلة الوعي الإسلامي،

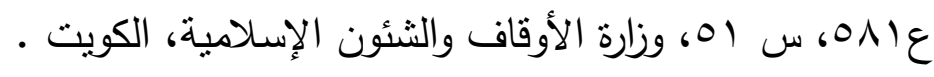

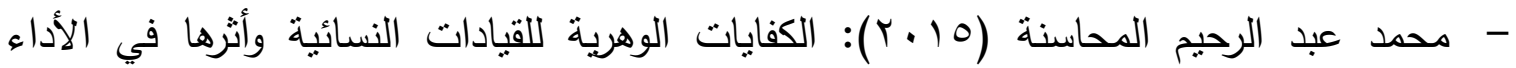

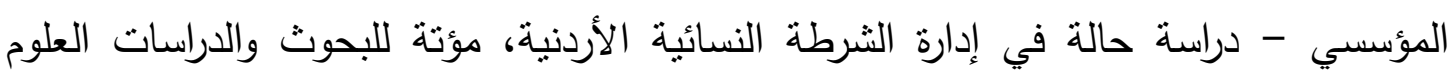

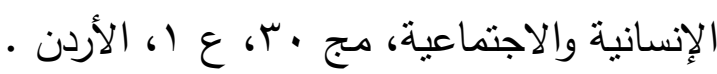

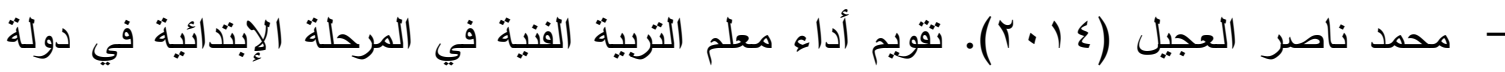

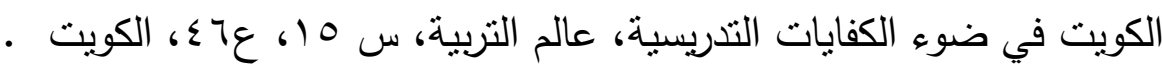

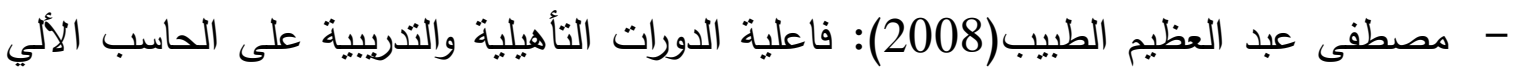
لتطوير أداء معلمي التعليم المتوسط في الجماهيرية الليبية، المؤتمر العلمي الأول، بعنوان"

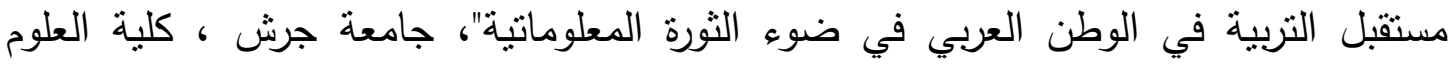
التربوية ، الأردن، أبريل. - مصطفي عبد السميع محمد (2012): أضواء على الخطة الاستراتيجية القومية لإصلاح التعليم

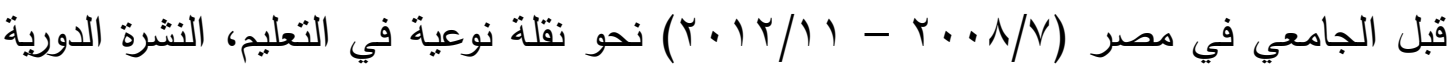
للمركز القومي للبحوث التنربوية والتتمية، ع109. - مصطفي عبد السميع محمد ، سهير حوالة (0.0 ب): إعداد المعلم تتميته وتدريبه، دار الفكر ، عمان - مضاوي عبد الرحمن الراثد (17 (1)): الكفايات الأدائية اللازمة لمعلمات الروضة التمية

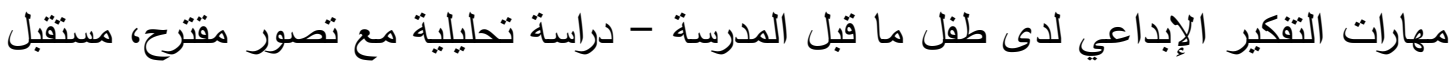


التربية العربية، مج 23، ع 102، القاهرة .

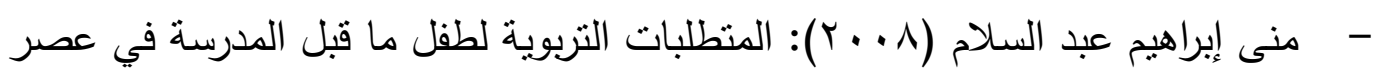

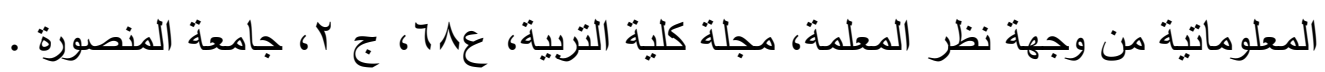

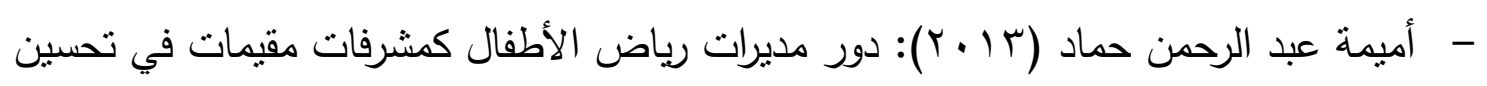

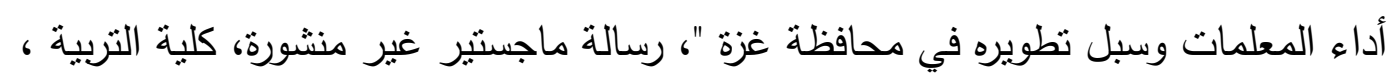
جامعة سوهاج.

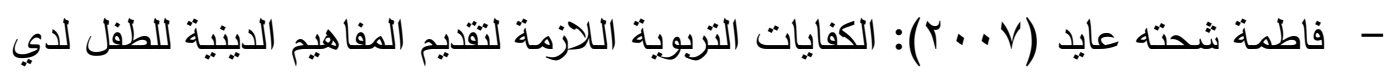

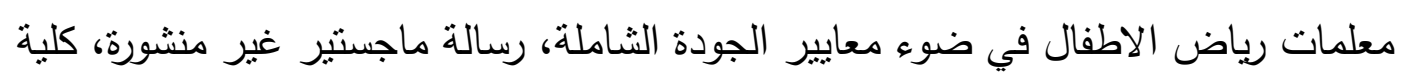
التربية، جامعة المنصورة.

منى إبراهيم عبد السلام حسن (2008): المتطلبات التربوية لطفل ما قبل المدرسة في عصر المرة

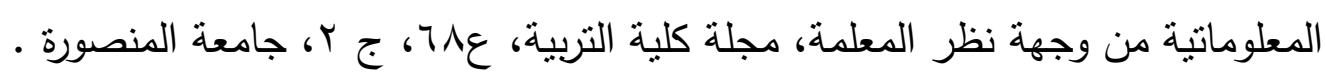

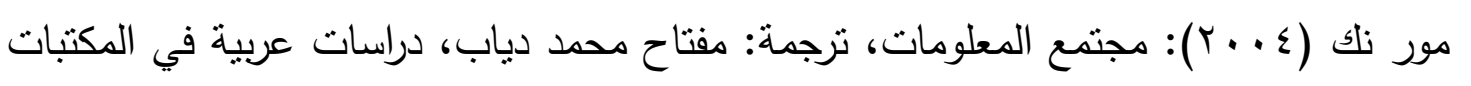

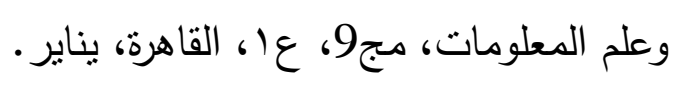

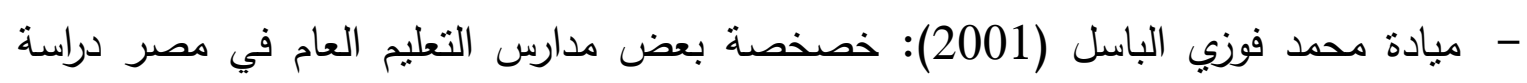

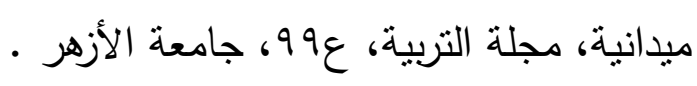

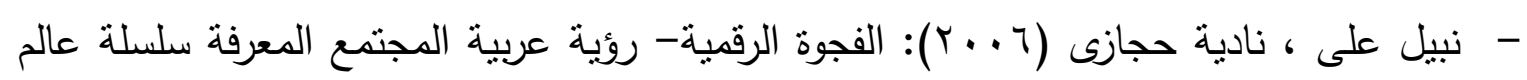

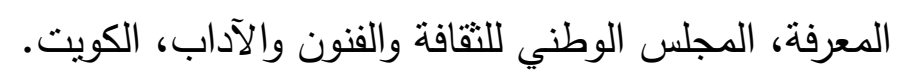

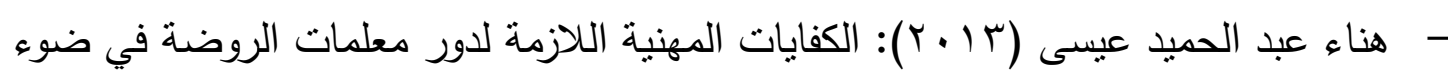
معايير الجودة، رسالة ماجستير غير منشورة، كلية التربية، جامعة بنها.

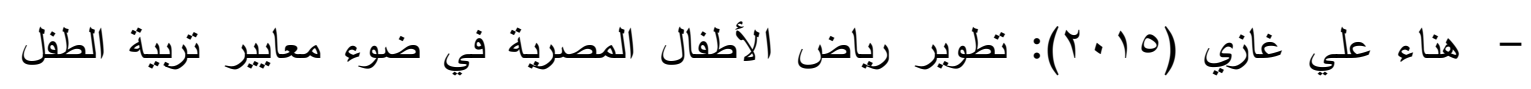

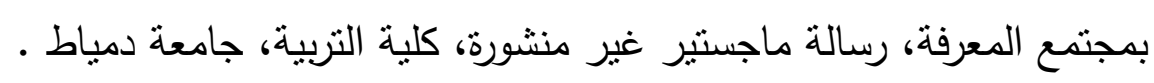

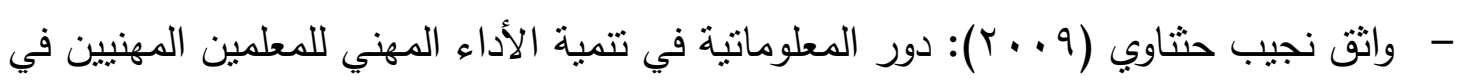

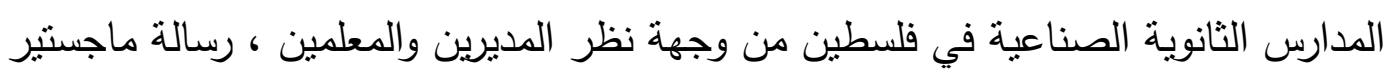

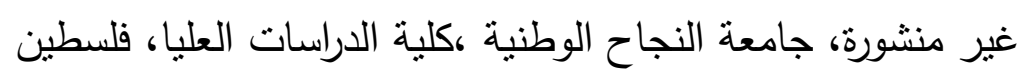

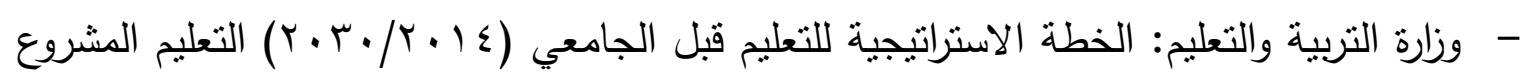
القومي لمصر ، وحدة التخطيط الاستراتيجي.

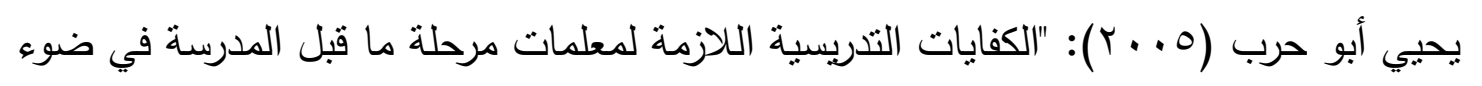

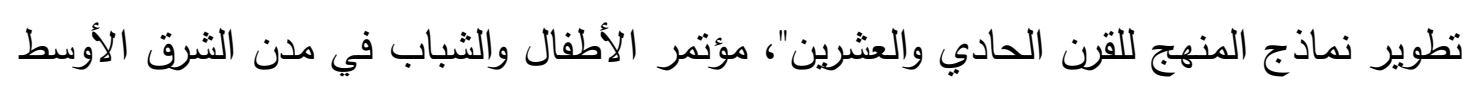

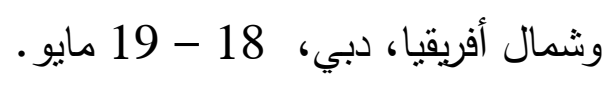
- - يوسف القسامية (2008): من أجل تتمية مستدامة وأمن وطني شامل، المؤتمر العلمي الأول " 
مستقبل التربية في الوطن العربي في ضوء الثورة المعلوماتية "، أبريل، جامعة جرش، كلية العلوم • التربوبة، الأردن

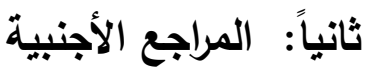

- Agan, Naim H. \&Carvalho, Maria G.(2010):The Knowledge Society: A Sustainability Paradigm, CADMUS, promoting leadership of thoughtthat leads to action, No. (1), Vol. (1), October.

- Baran,B\&Caltay (2006): "Knowledge Management and Online Communities of Practice in Teacher Education " The Turkish Online Journal of educational Technology - TOJET,v5,nl.

- Baran,B\&Caltay (2006): "Knowledge Management and Online Communities of Practice in Teacher Education " The Turkish Online Journal of educational Technology - TOJET,v5,nl.

- Downes, T. (2001) Making Better Connections: Models of teacher professional development for the integration of information and communication technology (ICT) into classroom practice. A report to the Commonwealth Department of Education, Science and Training, by Toni Downes, Andrew Fluck, Pam Gibbons, Ralph Leonard, Caroline Matthews, Ron Oliver, Margaret Vickers and Michelle Williams. http://www.detya.gov.au/schools/publications/002/professi onal.htm, [accessed 3.12. 2003).

- Hwan ,Ham \&Kyung, Cha (2009): Positioning Education in the Information Society The Transnational Diffusion of the Information and Communication Technology Curriculum, Comparative Education Review, vo153, no4.

- Hwan ,Ham \&Kyung, Cha (2009): Positioning Education in the Information Society The Transnational Diffusion of the Information and Communication Technology Curriculum, Comparative Education Review, vo153, no4. 
- Mäkinen, Heikki (2008); Knowledge Society or Information Society, Knowledge of Society White Papers 6, Version 2, 17 Nov.

- Ozhan Tingoy \& Sabri Serkan (2011): Informatics Education in Different Disciplines at University Level- Case Study: A survey of Students' Attitude Toward Informatics Technologies, TOJET: The Turkish Online Journal of Educational Technology - October 2011, volume 10, Issue 4.

- Selvn, Eileen (2003): Basic Performance competency and Measure if Teachers Doing it in Kindergarten, Recourses for Education ERIC,ED (47686).

- SonJaVelickovic \& Lazarstosic (2016): Preparedness of Educatons to Lmptement modern information technologies in their work with preschool children, International Journal of cognitive research in science, Engineering and Education (IJCRSEE), OOL.4, NO.1.

- Tishreen University Journal for Research and Scientific Studies -Economic and Legal Sciences Series Vol. (36) No. (5) 2014.

- Yves Punie and Marcelino (2005): "Cabrera with support from Marc Bogdanowicz, Dieter Zinnbauer and Elena Navajas", (all DG JRC-IPTS): The Future of ICT and Learning in the Knowledge Society, Technical Report Series, Report on a Joint DG JRC-DG EAC Workshop held in Seville, 20-21 October. 